\title{
A hitherto unnoticed adaptive radiation: epitoniid species (Gastropoda: Epitoniidae) associated with corals (Scleractinia)
}

\author{
Adriaan Gittenberger and Edmund Gittenberger \\ National Museum of Natural History, P.O. Box 9517, NL 2300 RA Leiden / Institute of Biology, University \\ Leiden.E-mail: gittenbergera@naturalis.nnm.nl
}

Keywords: Indo-Pacific; parasites; coral reefs; coral/mollusc associations; Epitoniidae; Epitonium; Epidendrium; Epifungium; Surrepifungium; new species; new genera; Scleractinia; Fungiidae; Fungia

\begin{abstract}
Twenty-two epitoniid species that live associated with various hard coral species are described. Three genera, viz. Epidendrium gen. nov., Epifungium gen. nov., and Surrepifungium gen. nov., and ten species are introduced as new to science, viz. Epidendrium aureum spec. nov., E. sordidum spec. nov., Epifungium adgranulosa spec. nov., E. adgravis spec. nov., E. adscabra spec. nov., E. marki spec. nov., E. nielsi spec. nov., E. pseudolochi spec. nov., E. pseudotwilae spec. nov., Surrepifungium patamakanthini spec. nov., and 'Epitonium' crassicostatum spec. nov. and ' $E$.' graviarmatum spec. nov. Although their identities as separate gene pools are convincingly demonstrated by molecular data, some of these species cannot be identified unequivocally on the basis of conchological characters alone. The shell shape and sculpture are only partially diagnostic because of interspecifically overlapping character states. In most of these cases, the operculum, jaw structure, radula, spawn and/or the habitat do reveal the identity. Most of these species are associated with only one or a restricted number of coral host species and have large ranges, similar to those of their hosts.
\end{abstract}

\section{Contents}

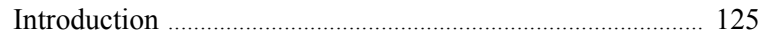

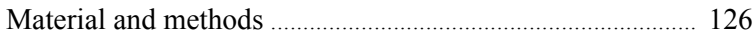

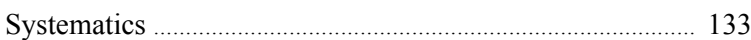

Surrepifungium gen. nov. .................................................... 133

S. costulatum (Kiener, 1838) ......................................... 137

S. ingridae (A. Gittenberger and Goud, 2000) ............ 140

S. oliverioi (Bonfitto and Sabelli, 2001) ........................ 141

S. patamakanthini spec. nov. ........................................... 144

Epitonium Röding, 1798, s.l. .............................................. 146

E. crassicostatum spec. nov. ............................................ 146

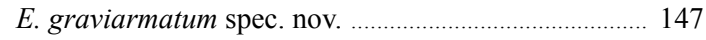

Epidendrium gen. nov. ........................................................ 148

E. aureum spec. nov. ................................................ 150

E. billeeanum (Dushane and Bratcher, 1965) .............. 152

E. dendrophylliae (Bouchet and Warén, 1986) ........... 153
E. sordidum spec. nov. .................................................. 155

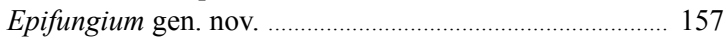

E. adgranulosa spec. nov. ............................................. 161

E. adgravis spec. nov. ...................................................... 163

E. adscabra spec. nov. ................................................. 167

E. hartogi (A. Gittenberger, 2003) .............................. 169

E. hoeksemai (A. Gittenberger and Goud, 2000) ........ 171

E. lochi (A. Gittenberger and Goud, 2000) .................. 175

E. marki spec. nov. ....................................................... 179

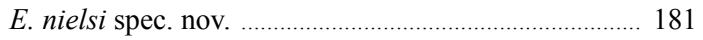

E. pseudolochi spec. nov. ............................................. 185

E. pseudotwilae spec. nov. ............................................. 187

E. twilae (A. Gittenberger and Goud, 2000) ................ 191

E. ulu (Pilsbry, 1921) ...................................................... 193

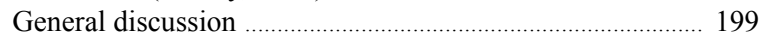

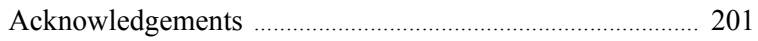

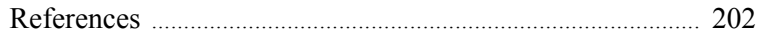

\section{Introduction}

The vernacular name "wentletraps" refers to a large group of snail species with usually slender conical shells, often ornamented with more or less prominent axial riblets. As far as known, the animals live as parasites, associated with coelenterates, either corals (Dushane, 1988a; A. Gittenberger et al., 2000), zoanthids (Robertson, 1981; Zahn, 1980) or sea anemones (den Hartog, 1987; Perron, 1978; Robertson, 1963, 1966, 1983a; Schimek, 1986). During this research project it turned out that these associations are restricted even more than initially thought. Some conchologically variable, alleged Epitonium species, e.g. "Epitonium ulu Pilsbry, 1921", were revealed to be groups of separate species with more or less broadly overlapping shell character states. Consequently, the species described in this paper cannot 
always be sharply diagnosed conchologically. The existence of several of these species became especially obvious while trying to characterize the wentletrap species that are associated with corals with molecular markers in an attempt to reconstruct their phylogeny. The data obtained by DNA sequencing (A. Gittenberger et al., in prep.) clearly indicate that there are a much larger number of separate gene pools than previously thought. Some of these species are widespread and several of them may occur sympatrically, though with different coral hosts. Single specimens could not always be identified without molecular data. However, when the identity of the coral host species was known for sure, with the locality where it was found, the identity of the associated epitoniid, determined also by DNA sequencing, could be predicted correctly in all cases.

This is the third contribution in a series of papers aiming at a better knowledge of the epitoniid species (Gastropoda: Epitoniidae) associated with corals (Scleractinia). For a more general introduction to the systematics, morphology and ecology of the large 'convenience genus' Epitonium, which ought to be split into smaller units, see also A. Gittenberger et al. (2000) and A. Gittenberger (2003).

\section{Material and methods}

Approximately 60,000 stony corals of the families Fungiidae, Dendrophyllidae and Euphyllidae were searched for epitoniids in the Indo-West Pacific off Egypt, Maldives, Thailand, Malaysia, Japan, Palau, Philippines, Indonesia and Australia. The fungiid hosts were usually identified twice from photographs and/or specimens, independently by A. Gittenberger and B.W. Hoeksema. H. Ditlev identified the euphyllids from photographs. The dendrophyllids were not identified. Most of the specimens used in this study were collected in a three years period (2001-2003) while scuba-diving in Indonesia and Palau during several excursions organized by the National Museum of Natural History Naturalis. This material was preserved in ethanol $96 \%$ to enable DNA-analyses. Additional research material from the Red Sea, Maldives, Thailand, Philippines, Australia, Hawaii and the Gulf of California, came partly from other institutes (see the institutional abbreviations below). To give an indication of the intraspecific variation, conspecific specimens are figured for several species. When mean values are indicated, the extremes and the number (n) of items measured are added.

The sculpture on the shells and the opercula, the structure of the mucus threads that connect the eggcapsules, and the morphology of the radulae and jaws were investigated and photographed with a scanning electron microscope (= SEM). The complete shells were photographed with a digital camera (Fujifilm FinePix 50i); those smaller than one $\mathrm{cm}$, and the eggcapsules, were photographed with this camera through a microscope, without using additional devices. Most of the epitoniid snails, their egg-capsules and the coral hosts were photographed in situ with a Sea \& Sea SX-1000 underwater camera. Unless stated otherwise, all photographs were taken by A. Gittenberger.

The shell height was measured as the length of a line (fig. 1: sh), running parallel to the columella, from the top of the protoconch to the most basal point of the aperture; the apertural height is the distance (fig. 1: ah) between the uppermost and the most basal point of the aperture. The shell width was measured perpendicular to the columella, as the distance (fig. 1: sw) between the left and the right side at the periphery of the shell; the width of teleoconch whorl T3 (figs 1-2: T3, T3w) is the distance between the left and the right side of teleoconch whorl $23 / 4-31 / 4$. It can only be measured when the protoconch-teleoconch border (PT) is centred, as is illustrated in figure 2. This character was routinely measured in Epitonium ulu Pilsbry, 1921, and conchological siblings, where it turned out to be discriminating to some extent. The 'shell height / shell width' $(=\mathrm{H} / \mathrm{W})$ and 'apertural height / shell height' $(=\mathrm{A} / \mathrm{H})$ values were only calculated for shells that are higher than $5 \mathrm{~mm}$, to allow for better comparisons. Specimens shorter than $5 \mathrm{~mm}$ were also studied, especially for the umbilical region.

In most cases the protoconch and the teleoconch whorls could easily be distinguished. The border between protoconch 1 (developed within an eggcapsule) and protoconch 2 (developed after hatching, before the settling stage) is not visible in epitoniid species. Protoconch 1 and 2 are therefore not described separately. In some species almost all protoconchs are badly damaged or broken away and no sculpture can be described for them. Usually the embryonic whorls remain relatively intact, however, still showing the characteristic sculpture of axial 


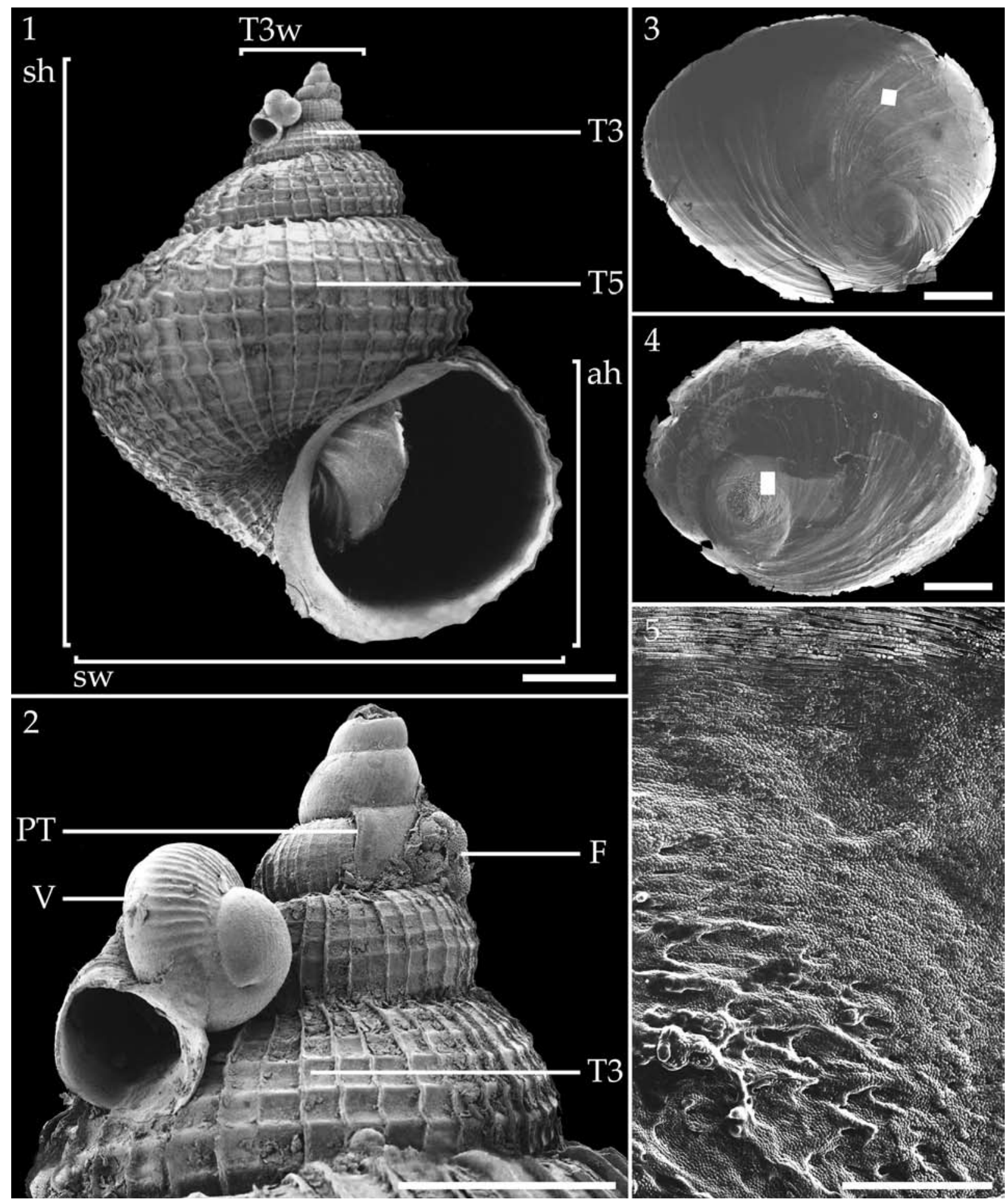

Figs 1-5. Shell and opercula, Palau. 1-2, Epidendrium sordidum spec. nov.; 1, shell; 2, protoconch and teleoconch whorls T1-T3. 3-5, Surrepifungium patamakanthini spec. nov.; 3, operculum, the outside (white square: detail in Fig. 138); 4, operculum, the inside (white square: detail in Fig. 5); 5, operculum, detail of the inside. Scale bars: 1, 3, $4=1 \mathrm{~mm} ; 2=0.5 \mathrm{~mm} ; 5=0.1 \mathrm{~mm}$. Abbrev.: ah, apertural height; F, foraminifer; PT, protoconch-teleoconch border; sh, shell height; sw, shell width; T3, teleoconch whorl 23/4-31/4; T3w, width of T3; T5, teleoconch whorl 43/4 - 51/4; V, vermetid shell. SEM photos. 


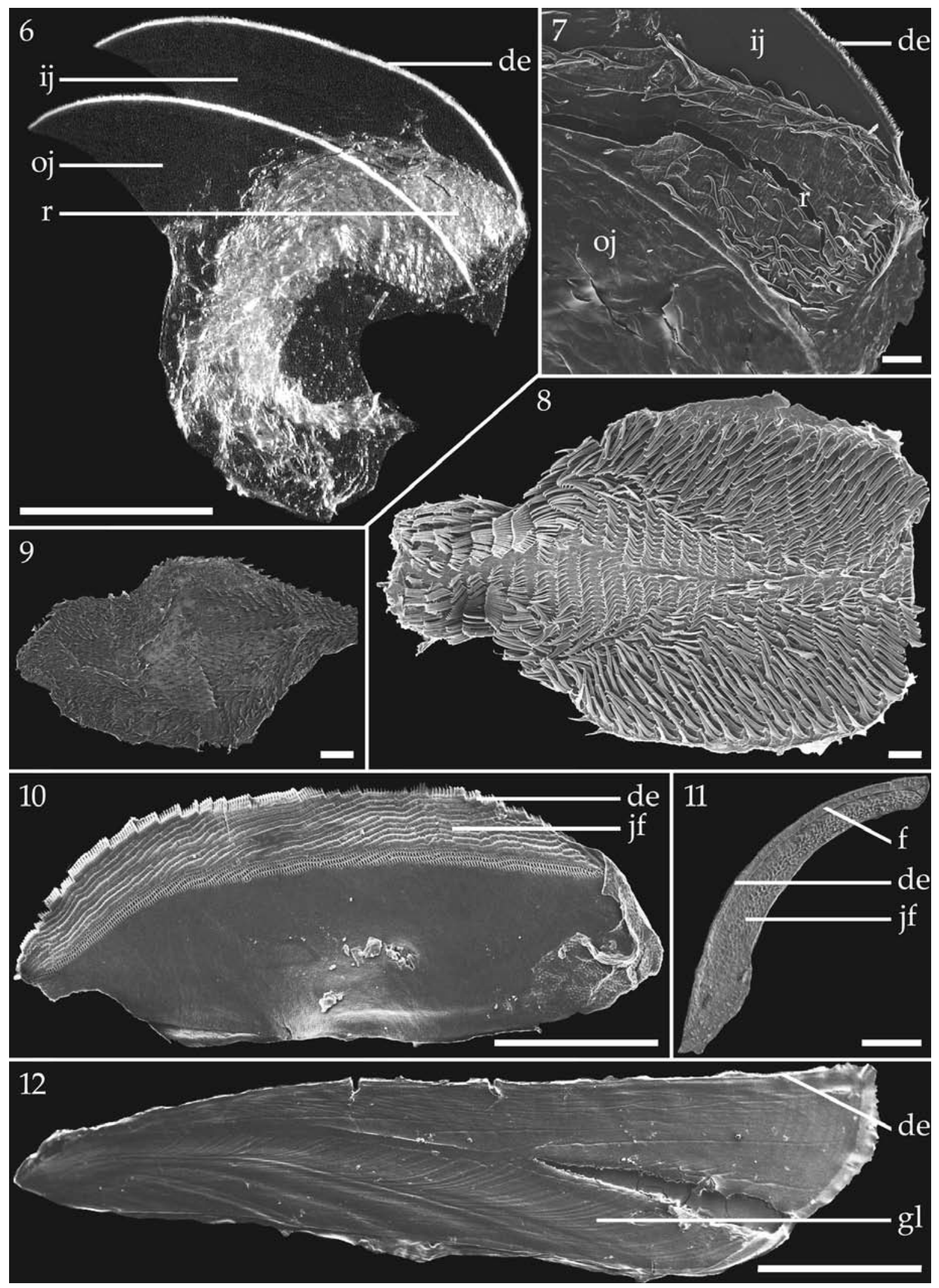


lines. The initial teleoconch whorls are referred to as whorls 1-3. A quantitative description of the shell sculpture is given for the $2^{\text {nd }}$ and the $5^{\text {th }}$ teleoconch whorl and, whenever relevant, also for the $3^{\text {rd }}$.

When there are over 20 spiral threads on a whorl, they are referred to as 'numerous'.

Although an epitoniid operculum can have a microsculpture on both its inside (figs 4-5) and outside (figs 3, 132-151), not enough material was available to study both sides for all species. We concentrated on the outside, because it has turned out to be speciesspecific for at least some epitoniids (Bonfitto and Sabelli, 2001; A. Gittenberger, 2003). On all SEM photographs (figs 132-151) the growth lines, which are clearly seen in e.g. figure 132, run from the lower left to the upper right corner (fig. 3). The sculpture, which can be more or less obsolete, is the same all over the outside of the operculum.

Jaws and radulae were studied for most species. They were prepared from specimens with a shell height exceeding $5 \mathrm{~mm}$.

Although the micro-sculpture on epitoniid jaws appears to be valuable for species identification, it has only rarely been described (A. Gittenberger, 2003). Jaws and/or radulae are here compared between 13 of the epitoniid species that are associated with Scleractinia, i.e. Epidendrium aureum spec. nov., E. sordidum spec. nov., Epifungium adgravis spec. nov., E. hartogi (A. Gittenberger, 2003), E. hoeksemai (A. Gittenberger and Goud, 2000), E. lochi (A. Gittenberger and Goud, 2000), E. nielsi spec. nov., E. pseudotwilae spec. nov., E. ulu (Pilsbry, 1921), Surrepifungium costulatum (Kiener, 1838), S. ingridae (A. Gittenberger and Goud, 2000), S. oliverioi (Bonfitto and Sabelli, 2001) and S. patamakanthini spec. nov., and 7 species that are associated with Actiniaria in the eastern Atlantic, i.e. Gyroscala lamellosa (Lamarck, 1822), Epitonium clathrus (Linnaeus, 1758 ) and E. clathratulum (Kanmacher, 1798), and

Figs 6-12. Radulae and jaws. 6-7, Surrepifungium patamakanthini spec. nov., radula in between the largely transparent [no SEM] jaws, Thailand; 6, overview, lateral view; 7, detail. 8-9, radulae; 8, Epifungium hartogi; 9, Cirsotrema varicosa. 10-11, jaws, outer surface; 10, C. varicosa; 11, Epifungium hoeksemai. 12, jaw, inner surface, Epitonium ancillottoi. 8-12, Sulawesi, Indonesia. Abbrev: de, denticulated jaw edge; f, flap; gl, growth lines; ij, inner surface of jaw; jf, jaw figures; oj, outer surface of jaw. Scale bars: $6,10,12=1 \mathrm{~mm} ; 7-9,11=0.1 \mathrm{~mm}$. Photos: through binoc. (6) and with SEM (7-12). the Indo-Pacific, i.e. E. ancillottoi T. and V. Cossignani, 1998, E. pyramidalis (Sowerby, 1844), E. spec. 1 and Cirsotrema varicosa (Lamarck, 1822). Epitonium spec. 1 occurs sympatrically with $E$. ancillotto $i$ in Indonesia and resembles it very closely in conchology. It was added here to illustrate that jaw and radula characters are valuable for distinguishing epitoniids in general. Epitonium spec. 1 will be described as new to science in an article about wentletraps associated with Actiniaria (Kokshoorn et al., in prep.). Some comparisons are made with the radular teeth of Janthina janthina (Linnaeus, 1758) (Gastropoda: Janthinidae) (fig. 16).

Two jaws flank the epitoniid radula (fig. 6). They are largely transparent, with a relatively smooth, lower edge and a whitish, denticulate, upper edge (figs 6-7, 10-12). These denticles can be acute, needle-like (figs 27-28), blunt (figs 25-26, 30-32) or lamellar (fig. 29). On the outside (figs 6-7: oj; figs 10-11), facing away from the radula, most denticles are somewhat convex (figs 25, 27, 30-31), while, on the inside (figs 6-7: ij; fig. 12), they are usually concave (fig. 26) to flat (fig. 32) and often pitted (figs $26,32)$. On the outside, some denticles have a kind of buttress (figs 30-31: b) against an inner plate (figs 20-32: ip). Adjunct to the denticles, a pattern of archlike (figs 17-19), pentagonal (figs 21-22), oval (fig. 20), square (fig. 32), or irregularly formed (figs 2324) figures may be present. On the outer surface of the jaw, the centre of each figure is either raised (figs 17,23 ) or sunken (figs 18-22) in comparison to its border. On the inner surface, the figures are engraved (figs 24, 32). On both sides pits (figs 21-24, 32) and holes (fig. 20) may be present. On the outside, just below the denticles, a jaw-flap may be present, which covers parts of the pattern (figs 11, 220, 226, 228-230, 234, 236-237, 240-244, 253-259: f). The pattern is revealed when this flap lies loose and is curved away, which is sometimes the case after SEM preparation (figs 219, 245, 250: f). Only then is the flap also visible from the inside (figs 249, 252-252: f). The denticles and figures are similar in size, parallel to the denticulate edge of the jaw, independent of the size of the snail (figs 243-244). Growth lines, which are rarely visible on the jaw (fig. 12: gl), indicate that growth proceeds in one direction, i.e. to the right in figure 12 .

An epitoniid tooth is attached to the radular plate along its bases (figs 13-15: ba). The part of the tooth 


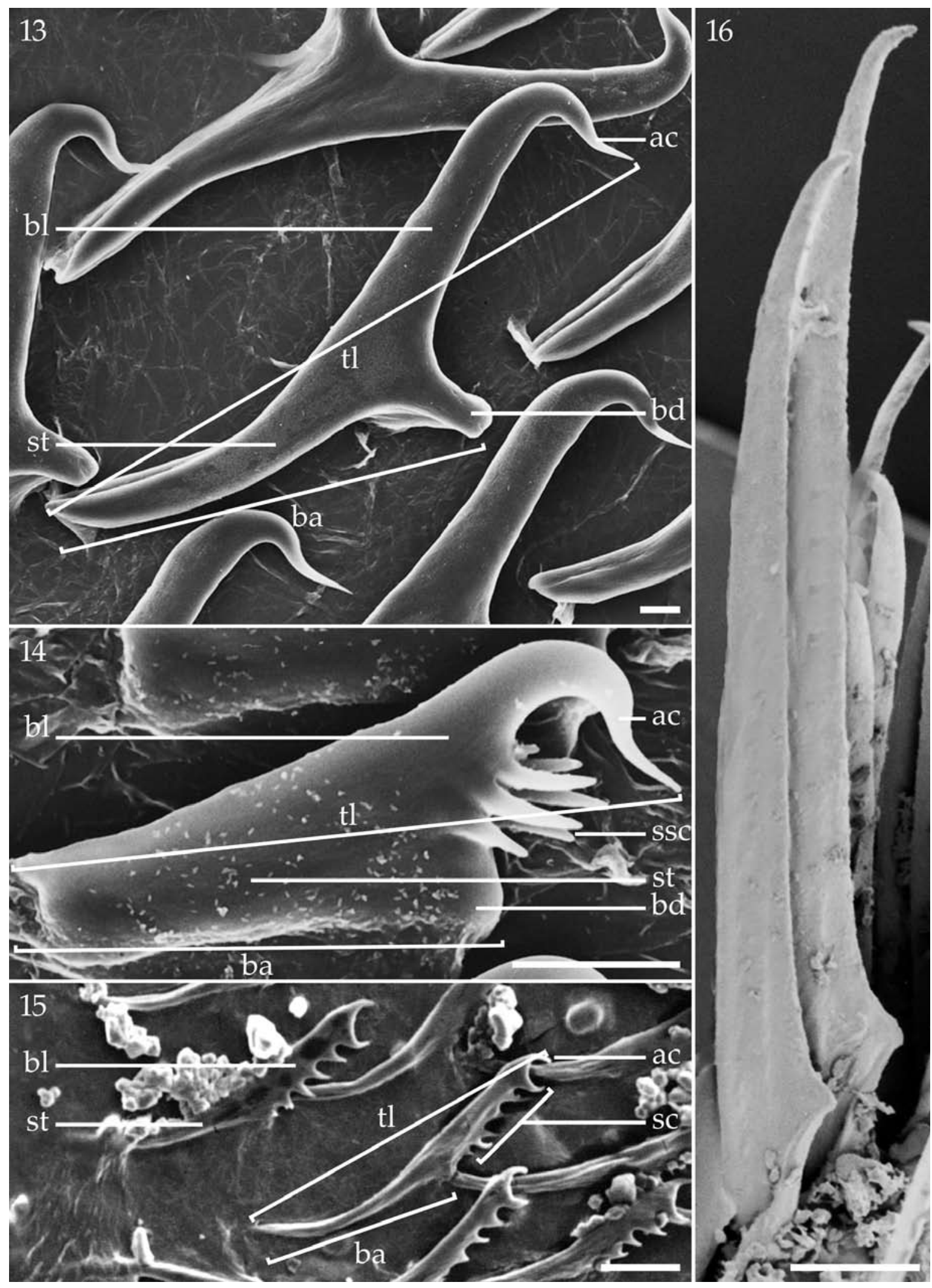


along the bases is called the stem, versus the part that is loose, the blade (figs 13-15: st, bl). A basal denticle is often present in between (figs 13-14: bd). Although the stem and the blade may be equally broad (fig. 13), the stem is usually more slender (fig. 15). Along the blade, which always ends with an apical cusp, secondary cusps may be present (figs 13-15: ac, sc). Split cusps (fig. 14: ssc) may be a malformation (fig. 209; A. Gittenberger, 2003), or a consistent character in a species (figs 14, 175). The length of a tooth is measured as the distance between the anterior end of the bases and the tip of the apical cusp (figs 13-15: tl).

Epitoniids have a ptenoglossan radula without a rachidian (Graham, 1965; Boss, 1982; Bandel, 1984; Page and Willan, 1988). No distinction can be made between marginal and lateral teeth. On an epitoniid radula the teeth may differ in size and number of secondary cusps. Half a row of teeth is described from the centre to the margin, by the number of teeth with a specific number of secondary cusps (table 2) and the sizes of the innermost, the largest, the penultimate and the ultimate (outermost) teeth (table 2). Additionally the position of the largest tooth is noted and a description is given of the morphology of the stem and the blade of a tooth (figs 13-15).

Because most of the epitoniids were conserved in alcohol $96 \%$, the tissue of these specimens was hardened which hampered dissection and further anatomical analyses.

The egg-capsules were photographed and measured submerged in ethanol. Although the ethanol may extract water, no clear difference in egg-capsule height and width was found when comparing photographs in ethanol and in situ.

The mucus threads that connect the egg-capsules are indicated as either straight or twisted. While scoring this character, a single mucus-thread, about 0.5 $\mathrm{mm}$ long, in between two egg-capsules, should be studied at about 500×. In general, in a mucus thread that is considered to be 'straight', up to two twists per $0.5 \mathrm{~mm}$ may still be present. In contrast, in a 'twisted' mucus-thread, at least five, and usually

Figs 13-16. Radular teeth. 13, Surrepifungium patamakanthini spec. nov., Palau. 14-15, Cirsotrema varicosa (14) and Epifungium adgravis spec. nov. (15), Sulawesi, Indonesia. 16, Janthina janthina, South Africa. Abbrev.: ac, apical cusp; ba, bases; bl, blade; bd, basal denticle; sc, secondary cusps; ssc, split secondary cusp; st, stem; tl, tooth length. Scale bars: $13-15=0.01 \mathrm{~mm} ; 16$ $=0.1 \mathrm{~mm}$. SEM photos. many more, twists are present. Often two straight mucus threads were found twisted around each other, giving the appearance that they are twisted themselves. Apart from this, pulling on a twisted mucus thread may strongly reduce the number of twists.

In Makassar, SW Sulawesi, Indonesia and Koror, Palau, egg-capsules of the species Epidendrium aureum spec. nov., Epifungium adgravis spec. nov., E. hartogi, E. hoeksemai, E. lochi, E. nielsi spec. nov., E. twilae (A. Gittenberger and Goud, 2000), E. ulu, Surrepifungium costulatum, S. ingridae and S. patamakanthini spec. nov. were kept in an aquarium. Each day, some capsules were cut open in a drop of seawater on a glass-slide, in such a way that the embryos and/or veligers were alive during observations. The developmental stages were studied then through a microscope and photographed with a digital camera or filmed with a video camera. Part of the results of this experiment was already published in the species description of E. hartogi (A. Gittenberger, 2003: 147, fig. 42). The development of the other species will here be compared with that of $E$. hartogi as described by A. Gittenberger (2003). The results will be described in more detail in a note about the development of epitoniid veligers in general (A. Gittenberger and Reijnen, in prep.).

Each examined sample from the Leiden Museum is cited as RMNH, followed by the institutional registration number. After a slash the material in question is specified in more detail, using the abbreviations sh (number of empty shells), sn (preserved snails), +e (with egg-capsules), $r$ (preserved radula), and $d$ (with DNA-extract). For example "RMNH 95082/2sh, $3 \mathrm{sn}+\mathrm{e}, \mathrm{r}, 2 \mathrm{~d}$ " refers to a sample with RNMH registration no. 95082, containing two empty shells, 3 snails with egg-capsules preserved in ethanol, one preserved radula and two DNA-extracts (of two snails). In the section Material, the type locality is listed first, followed by the countries and localities sorted by geological position, from West to East and from North to South. Because the material came from a variety of sources, not all the locality descriptions are equally detailed.

Unless stated otherwise, all specimens cited for the new species have to be considered paratypes.

In the text, the genera are dealt with in phylogenetic order, based on unpublished molecular (A. Gittenberger et al., in prep.), or on conchological data when molecular data are absent, viz. first Surrepifungium 


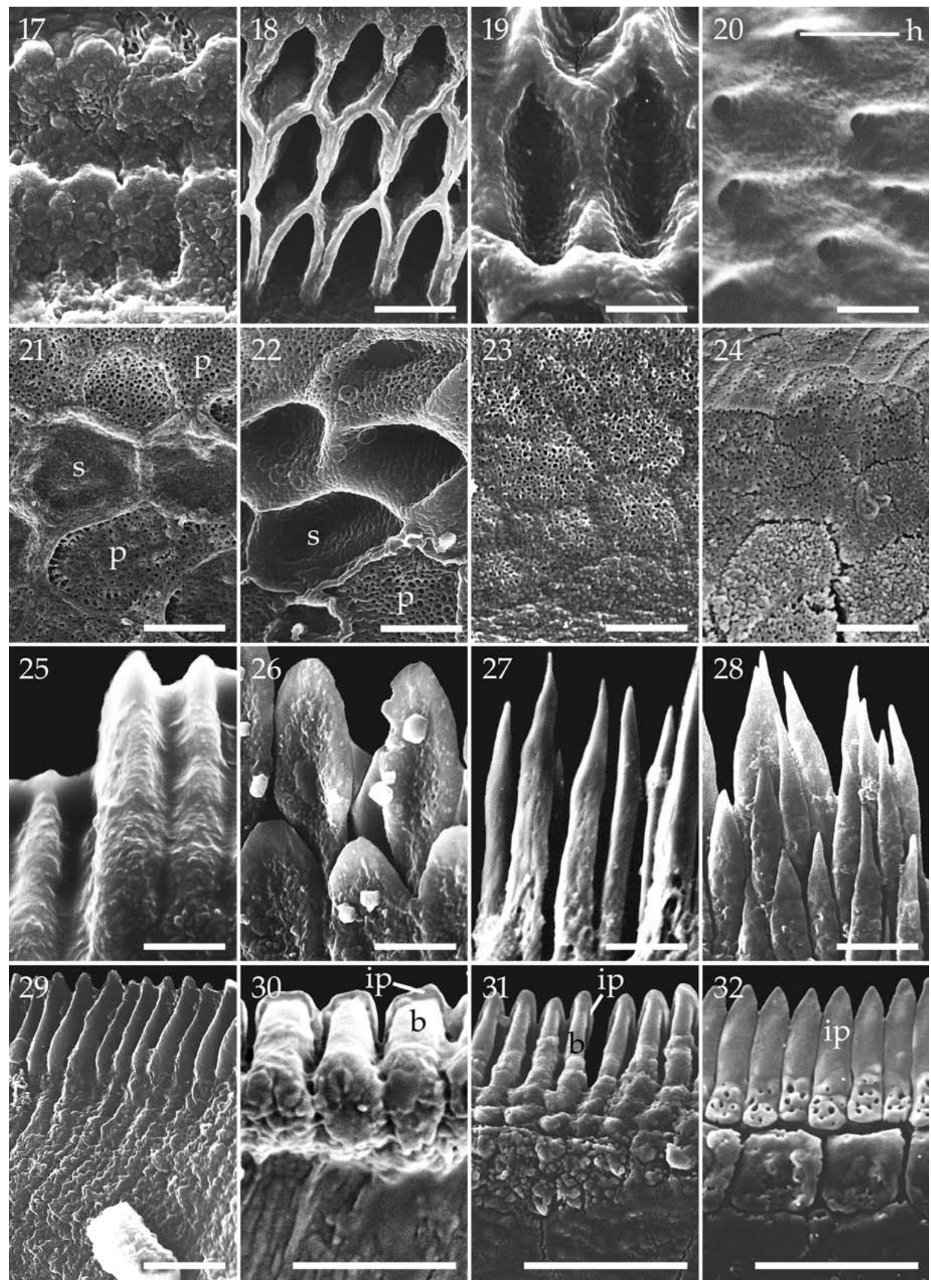


gen. nov., then Epitonium Röding, 1798, s.1., and finally Epidendrium gen. nov. and Epifungium gen. nov. The species are arranged alphabetically.

In general, the full (sub)genus name is used only for the first species name in a paragraph; in all following names with the same (sub)genus, it is abbreviated. When two genera with the same first letter are mentioned in one paragraph, the full name may be repeated to avoid confusion. The first time a snail species is mentioned and in the header of its description, the author(s) are added; most of these species are first mentioned in this materials and methods section. The author(s) of the coral species are only added in the "habitat" paragraphs.

Character states that are shared by all species of a genus, i.e. several "soft parts" and "spawn" characters, are only mentioned in the genus description.

Institutional abbreviations: AMS, Australian Museum, Sydney; ANSP, Academy of Natural Sciences, Philadelphia; BMNH, The Natural History Museum, London; CAS, California Academy of Sciences, San Francisco; MHNG, Muséum d'Histoire Naturelle, Genève; MZB, Zoological Museum of the University of Bologna, Italy; RMNH, National Museum of Natural History, Leiden (formerly Rijksmuseum van Natuurlijke Historie); WAM, Western Australian Museum, Perth.

\section{Systematics}

Epitoniidae Berry, 1910

In general, shells of epitoniids that are associated with corals are fragile, i.e. most of the protoconchs, the apertures, and the costal ribs are badly damaged already in life. Shells in other epitoniid species are usually more strongly built.

\section{Surrepifungium gen. nov.}

Type species. Epitonium ingridae A. Gittenberger and Goud, 2000.

Other species. Scala costulatum Kiener, 1838; Surrepifungium patamakanthini spec. nov.; Epitonium oliverioi Bonfitto and Sabelli, 2001.

Shell (table 1). Initial teleoconch whorls with multiple, lamellate costae, which are either fused to form broader ribs, as in Surrepifungium ingridae and $S$. patamakanthini spec. nov. (figs 95-96, 98, 113-114, 116; A. Gittenberger and Goud, 2000: 8, figs 23-24), or single, as in S. costulatum and S. oliverioi. A spiral sculpture is discernible on the teleoconch, either on all the whorls or gradually becoming obsolete. The latter is the case in $S$. costulatum (fig. 112), $S$. oliverioi (fig. 115) and S. patamakanthini spec. nov. The shells are fragile and usually most of the costal ribs are badly damaged (figs 33-41).

Operculum. Nine to twenty wavy threads per $0.1 \mathrm{~mm}$, running about perpendicular to the growth lines over the outside of the operculum (figs 136-139; Bonfitto and Sabelli, 2001: 271, fig. 2B). The threads are segmented by line fragments, which are convex towards the operculum edge.

Radula (table 2). All single teeth have a distinct basal denticle, an acute apical cusp and occasionally an inconspicuous, secondary cusp (figs 184-188, 204208). The teeth in a row differ distinctly only in size.

Jaw (table 2). The denticulate edge consists of several rows of acute, slender, pitted denticles, best visible from inside (figs 27, 28, 226-235). Usually 
Table 1. Shell dimensions and number of costal and spiral ribs on the teleoconch. The extremes and the mean value are followed by a semicolon and the number (n) of specimens when $\mathrm{n}>1$. Abbrev.: A/H, apertural height / shell height; $\mathrm{C} 2, \mathrm{C} 3, \mathrm{C} 5$, number of costal ribs on teleoconch whorls two, three and five; H/W, shell height/width index; obs., number of specimens in which costal or spiral ribs are obsolete; num., number of specimens in which costal or spiral ribs are numerous ( $>20)$; S2, S3, S5, number of spiral ribs on teleoconch whorls two, three and five; T3, width of teleoconch whorl $23 / 4-3 \frac{1}{4}$ in mm.

\begin{tabular}{|c|c|c|c|c|c|c|c|c|c|}
\hline Species & $\mathrm{H} / \mathrm{W} ; \mathrm{n}$ & $\mathrm{T} 3 ; \mathrm{n}$ & $\mathrm{A} / \mathrm{H} ; \mathrm{n}$ & C $2 ; n$ & $\mathrm{~S} 2 ; \mathrm{n}$ & C $3 ; n$ & $\mathrm{~S} 3 ; \mathrm{n}$ & C $5 ; n$ & S5; n \\
\hline \multirow[t]{2}{*}{ Surrepifungium costulatum } & $1.6-2.2$ & $?$ & $0.28-0.33$ & $16-20$ & $5-8$ & $?$ & $?$ & $16-26$ & 10 obs. \\
\hline & $1.9 ; 11$ & & $0.29 ; 10$ & $17.7 ; 10$ & $6.3 ; 10$ & & & $18.3 ; 10$ & \\
\hline \multirow[t]{2}{*}{ Surrepifungium ingridae } & $1.9-2.7$ & $?$ & $0.29-0.31$ & $15-19$ & $7-9$ & $?$ & $?$ & $20-31$ & $10-16$ \\
\hline & $2.2 ; 10$ & & $0.31 ; 10$ & $16.5 ; 10$ & $8.2 ; 10$ & & & $24.6 ; 10$ & $13.1 ; 10$ \\
\hline \multirow[t]{2}{*}{ Surrepifungium patamakanthini } & $1.8-2.8$ & $?$ & $0.24-0.35$ & $13-20$ & $5-9$ & $?$ & $?$ & $13-20$ & $7-11$ \\
\hline & $2.3 ; 22$ & & $0.28 ; 21$ & $15.8 ; 23$ & $6.1 ; 19$ & & & $16.1 ; 23$ & $8.2 ; 17$ \\
\hline \multirow[t]{2}{*}{ Surrepifungium oliverioi } & $1.6-2.0$ & $?$ & $0.30-0.39$ & $14-16$ & $4-7$ & $?$ & $?$ & $14-16$ & 10 obs. \\
\hline & $1.8 ; 10$ & & $0.35 ; 10$ & $14.9 ; 10$ & $5.9 ; 10$ & & & $14.9 ; 10$ & \\
\hline Epitonium crassicostatum & 2.2 & $?$ & 0.27 & 11 & obs. & 11 & 17 & 11 & 17 \\
\hline Epitonium graviarmatum & 1.7 & $?$ & 0.40 & 8 & obs. & 8 & obs. & 8 & obs. \\
\hline \multirow[t]{2}{*}{ Epidendrium aureum } & $1.3-2.0$ & $?$ & $0.31-0.44$ & $35-50$ & $6-9$ & $40-63$ & $7-9$ & $57-93$ & $8-12$ \\
\hline & $1.6 ; 18$ & & $0.38 ; 17$ & $39.8 ; 11$ & $7.1 ; 12$ & $47.5 ; 13$ & $7.7 ; 12$ & $70.0 ; 13$ & $9.9 ; 12$ \\
\hline \multirow[t]{2}{*}{ Epidendrium billeeanum } & $1.5-1.7$ & $?$ & $0.34-0.44$ & $25-41$ & $6-6$ & $31-49$ & $6-8$ & $42-64$ & $6-10$ \\
\hline & $1.6 ; 5$ & & $0.39 ; 5$ & $30.8 ; 4$ & $6 ; 4$ & $36.0 ; 4$ & $7 ; 4$ & $55.5 ; 4$ & $8.3 ; 4$ \\
\hline Epidendrium dendrophylliae & 1.8 & $?$ & 0.35 & 20 & 5 & 20 & 7 & 19 & 12 \\
\hline \multirow[t]{2}{*}{ Epidendrium sordidum } & $1.1-1.8$ & $?$ & $0.32-0.49$ & $25-36$ & $4-7$ & $29-43$ & $5-7$ & $30-74$ & $7-9$ \\
\hline & $1.3 ; 17$ & & $0.41 ; 17$ & $31.5 ; 13$ & $5.9 ; 14$ & $33.4 ; 13$ & $6.9 ; 14$ & $46.3 ; 14$ & $8.5 ; 15$ \\
\hline \multirow[t]{2}{*}{ Epifungium adgranulosa } & $2.0-3.2$ & $0.63-0.80$ & $0.23-0.33$ & $18-31$ & $2-8$ & $19-32$ & $4-10$ & $18-32$ & $6-17$ \\
\hline & $2.5 ; 27$ & $0.71 ; 36$ & $0.28 ; 19$ & $23.0 ; 33$ & $5.8 ; 13$ & $24.1 ; 33$ & $7.4 ; 17$ & $25.2 ; 33$ & $11.5 ; 25$ \\
\hline \multirow[t]{2}{*}{ Epifungium adgravis } & $2.3-3.0$ & $0.77-0.92$ & $0.23-0.30$ & $23-29$ & $4-6$ & $23-32$ & $5-10$ & $22-31$ & $5-12$ \\
\hline & $2.7 ; 14$ & $0.83 ; 21$ & $0.27 ; 10$ & $24.8 ; 18$ & $5.2 ; 13$ & $25.6 ; 19$ & $6.4 ; 13$ & $25.4 ; 19$ & $8.9 ; 15$ \\
\hline \multirow[t]{4}{*}{ Epifungium adscabra } & $1.9-2.3$ & $0.66-0.75$ & $0.25-0.37$ & $16-22$ & $5-5$ & $16-25$ & $5-10$ & $17-26$ & $7-19$ \\
\hline & $2.0 ; 14$ & $0.70 ; 11$ & $0.31 ; 12$ & $19.2 ; 10$ & $5.0 ; 9$ & $19.5 ; 10$ & $6.8 ; 6$ & $20.2 ; 9$ & $11.0 ; 7$ \\
\hline & & & & & 2 obs. & & 5 obs. & & 2 obs. \\
\hline & & & & & & & & & 1 num. \\
\hline \multirow[t]{2}{*}{ Epifungium hartogi } & $1.4-1.8$ & $?$ & $0.34-0.43$ & $20-26$ & $9-12$ & $?$ & $?$ & $32-40$ & $29-40$ \\
\hline & $1.6 ; 13$ & & $0.38 ; 10$ & $22.8 ; 23$ & $10.3 ; 22$ & & & $37.3 ; 8$ & $34.3 ; 12$ \\
\hline \multirow[t]{2}{*}{ Epifungium hoeksemai } & $1.6-2.4$ & $0.63-0.83$ & $0.27-0.38$ & $21-30$ & $5-9$ & $23-32$ & $6-13$ & $27-47$ & $12-26$ \\
\hline & $2.0 ; 25$ & $0.74 ; 18$ & $0.31 ; 15$ & $24.7 ; 18$ & $6.9 ; 17$ & $26.7 ; 18$ & $8.9 ; 18$ & $32.7 ; 18$ & $17.0 ; 18$ \\
\hline \multirow[t]{2}{*}{ Epifungium lochi } & $2.3-3.1$ & $0.71-0.78$ & $0.23-0.37$ & $20-29$ & $5-9$ & $20-29$ & $6-11$ & $21-35$ & $8-15$ \\
\hline & $2.7 ; 9$ & $0.74 ; 9$ & $0.27 ; 9$ & $23.1 ; 9$ & $6.9 ; 9$ & $24.6 ; 9$ & $8.0 ; 9$ & $26.3 ; 9$ & $11.0 ; 9$ \\
\hline \multirow[t]{2}{*}{$\overline{\text { Epifungium marki }}$} & $2.4-2.9$ & $0.81-0.82$ & $0.25-0.32$ & $23-23$ & $5-6$ & $23-25$ & $6-6$ & $23-31$ & $7-8$ \\
\hline & $2.7 ; 4$ & $0.82 ; 4$ & $0.28 ; 4$ & $23.0 ; 4$ & $5.3 ; 4$ & $24.0 ; 4$ & $6 ; 4$ & $26.0 ; 4$ & $7.8 ; 4$ \\
\hline \multirow[t]{2}{*}{ Epifungium nielsi } & $2.0-3.1$ & $0.65-0.82$ & $0.22-0.34$ & $16-28$ & $4-7$ & $23-34$ & $6-10$ & $17-39$ & $6-17$ \\
\hline & $2.5 ; 26$ & $0.73 ; 37$ & $0.25 ; 15$ & $22.0 ; 36$ & $5.8 ; 22$ & $23.8 ; 35$ & $7.7 ; 27$ & $25.6 ; 35$ & $11.0 ; 30$ \\
\hline \multirow[t]{2}{*}{ Epifungium pseudolochi } & $2.4-3.0$ & $0.71-0.74$ & $0.25-0.27$ & $23-24$ & $6-6$ & $24-25$ & $8-9$ & $26-27$ & $10-10$ \\
\hline & $2.7 ; 2$ & $0.73 ; 2$ & $0.26 ; 2$ & $23.5 ; 2$ & $6 ; 2$ & $24.5 ; 2$ & $8.5 ; 2$ & $26.5 ; 2$ & $10 ; 2$ \\
\hline \multirow[t]{2}{*}{ Epifungium pseudotwilae } & $1.2-2.2$ & $0.83-1.03$ & $0.34-0.65$ & $17-23$ & $5-6$ & $18-24$ & 10 obs. & $22-39$ & 10 obs. \\
\hline & $1.3 ; 19$ & $0.91 ; 15$ & $0.38 ; 12$ & $19.9 ; 19$ & $\begin{array}{l}5.5 ; 2 \\
8 \text { obs. }\end{array}$ & $22.1 ; 19$ & & $29.7 ; 19$ & \\
\hline \multirow[t]{3}{*}{ Epifungium twilae } & $1.0-1.7$ & $0.91-1.14$ & $0.33-0.59$ & $22-30$ & $5-6$ & $24-30$ & 12 obs. & $26-57$ & 12 obs \\
\hline & $1.4 ; 18$ & $0.97 ; 15$ & $0.42 ; 15$ & $25.6 ; 14$ & $5.5 ; 2$ & $26.5 ; 14$ & & $39.3 ; 14$ & \\
\hline & & & & & 10 obs. & & & & \\
\hline \multirow[t]{3}{*}{ Epifungium ulu } & $1.7-3.3$ & $0.62-0.78$ & $0.21-0.36$ & $17-26$ & $3-8$ & $17-27$ & $3-8$ & $17-27$ & $5-8$ \\
\hline & $2.3 ; 26$ & $0.69 ; 23$ & $0.27 ; 20$ & $20.1 ; 24$ & $4.0 ; 10$ & $20.7 ; 24$ & $4.9 ; 15$ & $21.0 ; 23$ & $5.9 ; 19$ \\
\hline & & & & & 14 obs. & & 9 obs. & & 5 obs. \\
\hline
\end{tabular}


Table 2. Radula and jaw. Half a radular row is described from the innermost to the outermost tooth. The lengths of the smallest, largest, penultimate and ultimate tooth are given in $\mathrm{mm}$; the position of the largest tooth is indicated between brackets. The Radular formula $\mathrm{N} / \mathrm{s}$ indicates the number of teeth $(\mathrm{N})$ with s secondary cusps. Abbrev.: Loc., Locality; $\mathrm{SH}$, shell height in mm; d/.05, denticles per 0.05 $\mathrm{mm}$; Max d, maximum denticle size in $\mathrm{mm}$; Fl W, maximum flap width in mm. Localities: Bali = Bali, Indonesia; Berau = Berau islands, Kalimantan, Indonesia; Mald = Vilamendhoo island, Ari Atoll, Maldives; Palau = Koror, Palau; Phil = Cebu, Philippines; S Sul = Spermonde archipelago, Sulawesi, Indonesia; Thai = Phiphi Islands, Krabi, Thailand. Hosts: Ccra, Ctenactis crassa; Cech, C. echinata; Den, Dendrophyllidae; Fcon, Fungia concinna, Ffun, F. fungites; Fgra, F. gravis; Fhor, F. horrida; Frep, F. repanda; Fpau, F. paumotensis; Fscu, F. scutaria; Hlim, H. limax, Psim, P. simplex; Sden, S. dentata; Srob, S. robusta.

\begin{tabular}{|c|c|c|c|c|c|c|c|c|}
\hline \multirow{2}{*}{$\begin{array}{l}\text { Specimen } \\
\text { Species }\end{array}$} & \multirow[b]{2}{*}{ Loc. } & \multirow[b]{2}{*}{ Host } & \multirow[b]{2}{*}{$\mathrm{SH}$} & \multicolumn{2}{|l|}{ Radula } & \multicolumn{3}{|l|}{ Jaw } \\
\hline & & & & Teeth lengths (mm) & Radular formula & $\mathrm{d} / .05$ & Max d & $\mathrm{Fl} \mathrm{W}$ \\
\hline \multirow[t]{2}{*}{ Surrepifungium costulatum } & Palau & Cech & 26.1 & $0.0300 .195(20) 0.1950 .120$ & $1 / 1 \quad 18 / 0 \quad 1 / 1 \quad 1 / 0$ & 14 & 0.020 & 0.019 \\
\hline & S Sul & Cech & 31.6 & $0.0650 .130(7) 0.1080 .082$ & $1 / 122 / 0$ & 14 & 0.030 & 0.020 \\
\hline \multirow[t]{2}{*}{ Surrepifungium ingridae } & Palau & Frep & 20.4 & $0.0210 .142(14) 0.0920 .061$ & $2 / 117 / 02 / 1$ & 19 & 0.022 & 0.040 \\
\hline & S Sul & Srob & 18.3 & $0.0160 .124(13) 0.0850 .062$ & $2 / 116 / 02 / 1$ & 20 & 0.021 & 0.052 \\
\hline \multirow[t]{3}{*}{ Surrepifungium oliverioi } & Palau & Hlim & 10.0 & $0.0300 .135(17) 0.1350 .053$ & $1 / 117 / 0$ & $?$ & $?$ & $?$ \\
\hline & Palau & Hlim & 17.1 & $0.0330 .190(19) 0.1900 .175$ & $1 / 121 / 0$ & $?$ & $?$ & $?$ \\
\hline & Mald & Hlim & 18.1 & $0.0490 .227(18) 0.2270 .169$ & $1 / 118 / 0$ & 16 & 0.008 & 0.012 \\
\hline \multirow[t]{3}{*}{ Surrepifungium patamakanthini } & Palau & Ffun & 19.0 & $0.0300 .150(11) 0.1500 .102$ & $1 / 111 / 0$ & 17 & 0.022 & 0.020 \\
\hline & Palau & Ccra & 23.0 & $0.0370 .171(11) 0.1710 .126$ & $1 / 111 / 0$ & 16 & 0.022 & $?$ \\
\hline & Mald & Fhor & 20.6 & $0.0320 .155(12) 0.1530 .155$ & $1 / 111 / 0$ & 18 & 0.020 & $?$ \\
\hline \multirow[t]{3}{*}{ Epidendrium aureum } & Thai & Den & 14.5 & $0.0310 .119(21) 0.0620 .042$ & $1 / 129 / 0$ & 46 & 0.0048 & $?$ \\
\hline & S Sul & Den & 11.8 & $0.0210 .127(13) 0.0950 .086$ & $1 / 129 / 0$ & 38 & 0.0070 & 0.026 \\
\hline & S Sul & Den & 12.3 & $0.0300 .143(22) 0.0840 .061$ & $1 / 133 / 0$ & $?$ & $?$ & 0.026 \\
\hline \multirow[t]{3}{*}{ Epidendrium sordidum } & S Sul & Den & 16.0 & $0.0410 .108(46) 0.0760 .074$ & $\begin{array}{l}1 / 11 / 23 / 37 / 49 / 5 \\
4 / 61 / 92 / 7 \ldots 8 / 5 \\
9 / 43 / 52 / 3 \\
\text { (59 teeth in total) }\end{array}$ & 30 & 0.0063 & 0.0163 \\
\hline & Phil & Den & 13.1 & $?$ & At least 55 teeth & 31 & 0.0080 & 0.0189 \\
\hline & S Sul & Den & 12.0 & $0.044 ? ? ?$ & $\begin{array}{l}\text { At least } 50 \text { teeth, } \\
\text { max. } 9 \text { sec. cusps / } \\
\text { tooth }\end{array}$ & & & \\
\hline Epifungium nielsi & Berau & Fpau & 14.0 & $0.0350 .056(12) 0.0480 .037$ & $\begin{array}{lllll}1 / 1 & 1 / 2 & 2 / 3 & 5 / 4 & 1 / 5 \\
2 / 6 & 6 / 5 & 1 / 4 & 1 / 1\end{array}$ & 71 & 0.0030 & 0.0142 \\
\hline \multirow[t]{2}{*}{ Epifungium adgravis } & Bali & Fgra & 12.4 & $0.0200 .042(10) 0.0360 .022$ & 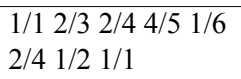 & $?$ & $?$ & $?$ \\
\hline & S Sul & Fgra & 10.0 & $?$ & $?$ & 56 & 0.0033 & 0.010 \\
\hline \multirow[t]{2}{*}{ Epifungium hoeksemai } & Palau & Ffun & 11.5 & $0.0180 .027(18) 0.0270 .022$ & $1 / 19 / 21 / 3 \quad 8 / 2$ & 58 & 0.0032 & 0.0120 \\
\hline & Palau & Ffun & 12.4 & $0.0180 .028(17) 0.0280 .025$ & $1 / 117 / 2$ & 64 & 0.0030 & 0.0074 \\
\hline Epifungium lochi & S Sul & $F \cos$ & 9.3 & $0.0180 .034(8) 0.0340 .028$ & $\begin{array}{l}3 / 22 / 34 / 41 / 51 / 4 \\
1 / 3\end{array}$ & 72 & 0.0018 & 0.0060 \\
\hline \multirow[t]{4}{*}{ Epifungium ulu } & S Sul & Fscu & 9.1 & $0.0290 .049(7) 0.0380 .028$ & $1 / 22 / 38 / 4 \quad 1 / 33 / 2$ & $?$ & $?$ & $?$ \\
\hline & S Sul & Fscu & 10.0 & $0.0280 .050(8) 0.0390 .028$ & $1 / 23 / 39 / 4 \quad 1 / 51 / 3$ & 65 & $?$ & $?$ \\
\hline & S Sul & Frep & 14.0 & $?$ & $?$ & 58 & 0.0042 & 0.0131 \\
\hline & Bali & Ffun & 28.2 & $?$ & $?$ & 50 & 0.0038 & 0.0135 \\
\hline Epifungium pseudotwilae & Bali & Sden & 13.2 & $0.0290 .041(5) 0.0320 .028$ & $\begin{array}{l}2 / 2 \quad 1 / 3 \quad 2 / 4 \quad 1 / 3 \quad 1 / 2 \\
4 / 3\end{array}$ & $?$ & $?$ & $?$ \\
\hline Epifungium hartogi & S Sul & Psim & 5.4 & $0.0220 .047(24) 0.0470 .040$ & $\begin{array}{l}1 / 14 / 27 / 37 / 44 / 5 \\
1 / 61 / 2\end{array}$ & 65 & 0.0035 & 0.018 \\
\hline
\end{tabular}


no particular structure is visible on the inner surface (figs 228-235), but rarely there is a vague, irregular pattern (figs 227-232). On the outer surface, along the line where the jaw-flap merges with the jaw, a pattern of sunken figures (resembling figs 21-22), which are usually pentagonal and pitted, is present (figs 226, 228, 230-231, 234); underneath this line, the pattern is vague or obsolete.

Soft parts. The animal is whitish, with small, dark eyespots.

Spawn. Egg-capsules irregular pentagonal, dropshaped, and covered with coral-sand grains. A straight mucus thread, finely sculptured with longitudinal lines, connects the capsules along their bases (on the left in figs 264, 266, 268, 270). When veligers hatch, an egg-capsule breaks open at the apical side (on the right in figs $264,266,268,270)$. The uncleaved eggs are $0.077 \mathrm{~mm}(\mathrm{n}=10$ per species $)$ in diameter. The development from eggs to veligers in the egg-capsules of Surrepifungium costulatum, S. ingridae and S. patamakanthini spec. nov. resembles that described for Epifungium hartogi by A. Gittenberger (2003: 147, fig. 42); no data are available for $S$. oliverioi.

Habitat. The snails live at the surface of the sand or buried within it, underneath fungiid corals (Fungiidae). They were never found on the corals themselves. In contrast, snails belonging to Epifungium gen. nov. were seen nearby, but crawling on the coral surface.

Etymology. Surrepifungium is composed after "surrepi", Latin for "to creep or crawl up from below", and "fungium", referring to the coral host family "Fungiidae". The name can also be read as "surr", a wrong inflection of "sub", standing for "below" and "epifungium", after Epifungium gen. nov. The gender is neuter, i.e. with the ending "ium".

Differentiation. No shell characters are consistently present in Surrepifungium gen. nov. spp., which can distinguish them from all species in Epitonium and Epifungium gen. nov. The fused, lamellate costae and the fading spiral sculpture are both characteristic, but not present in all Surrepifungium gen. nov. species. Most epitoniids of other genera have spiral sculpture on all teleoconch whorls and do not have fused, lamellate costae.
A similar operculum sculpture of wavy threads, running about perpendicular to the growth lines, is present in Epifungium gen. nov. (figs 140-151). In that genus, however, twenty to forty threads per $0.1 \mathrm{~mm}$ are present instead of nine to twenty in Surrepifungium gen. nov. In Epidendrium aureum spec. nov. (figs 132-133), E. sordidum spec. nov. (fig. 134) and Epitonium pyramidalis (fig. 135), no operculum sculpture is present, except for the growth lines. The operculum sculpture of other epitoniids is unknown.

In several species of other epitoniid genera, similar teeth with a distinct basal denticle, an acute apical cusp and occasionally an inconspicuous, secondary cusp are present, viz. in Acirsa subdecussata (Cantraine, 1835) (in Bouchet and Warén, 1986: 470, fig. 1098), Cirsotrema varicosa (figs 152, 195), Epidendrium aureum spec. nov. (figs 160-161, 183, 203), Epitonium celesti (in Bouchet and Warén, 1986: 470, fig. 1099), E. clathrus (fig. 156) and E. pyramidalis (figs 157, 180, 200). Even in Janthina janthina (fig. 16) (Janthinoidea Lamarck, 1810 [= Epitoniacea Berry, 1910], Janthinidae) similar teeth occur, but these can be about twenty times larger than the largest ones found in Surrepifungium gen. nov.

The structure of the jaws appears to be most clearly diagnostic for the genus. In Epitonium ancillottoi and E. spec. 1 (figs 30, 219-222), which both resemble Surrepifungium ingridae conchologically, and in epitoniids of Epifungium gen. nov. (figs 243263), which are associated with the same coral host species as the Surrepifungium gen. nov. species, there is only a single row of blunt denticles on the jaw-edge instead of several rows of acute ones. In Cirsotrema varicosa and Gyroscala lamellosa (figs 215-217), which differ clearly by their strong shells with a rough surface, there are multiple rows of denticles. These two species closely resemble each other in jaw structure, differing from the Surrepifungium gen. nov. species by relatively blunt denticles, no jaw-flap and a distinct, outside jaw-pattern with arch-like, raised and sunken figures (figs 17-19, 215-216).

Instead of the drop-shaped egg-capsules known from Surrepifungium gen. nov., most epitoniids have oval to roundish ones. Epitonium clathrus (L., 1758), a sea-anemone-eating, Atlantic epitoniid, also has drop-like capsules (Vestergaard, 1935). These eggcapsules however, are triangular instead of pentagonal. Epitonium clathrus further differs from Surrepifun- 
gium gen. nov. species by its strong shell and ribs, and always has some radular teeth with more than one secondary cusp (figs 156, 179, 199).

The habitat is partly shared with several Epifungium gen. nov. species, which occasionally occur on the bottom underneath fungiids. When they were found together $(\mathrm{n}=24)$, the snails of Epifungium gen. nov. were on the coral and those of Surrepifungium gen. nov. on or in the sand underneath. This is more likely due to a dislike of sand by the snails of Epifungium gen. nov., than due to interspecific competition (A. Gittenberger and Hoeksema, in prep.). The habitat seems not to be shared with any other epitoniids.

\section{Surrepifungium costulatum (Kiener, 1838)}

Scalaria costulatum Kiener, 1838: 5, pl. 2 fig. 4.

Epitonium costulatum (Kiener, 1838); Robertson, 1963: 57, pl. 5 fig. 4; 1970: 45; Loch, 1982: 4, 1 fig.; Dushane, 1988a: 31, figs 1, 2; A. Gittenberger et al., 2000: 3, 4, figs 3-6, 22, 25, 38-41, 47.

Material. Holotype: MHNG 1152/16. MALDIVES. Ari Atoll, off Vilamendhoo Island (hosted by Herpolitha limax), $2 \mathrm{sn} / \mathrm{sh}+\mathrm{e}$, d. THAILAND. Krabi, Phiphi Islands (hosted by Ctenactis echinata, H. limax, Fungia (Fungia) fungites), 26sn/sh+12e, $5 \mathrm{~d}$. INDONESIA. SW Sulawesi, Spermonde archipelago (hosted by $C$. echinata, H. limax), $31 \mathrm{sn} / \mathrm{sh}+11 \mathrm{e}, 7 \mathrm{~d}, 2 \mathrm{r}$. Bali (hosted by C. echinata, H. limax, Sandalolitha dentata, S. robusta), 16sn/ sh $+4 \mathrm{e}$. Ambon (hosted by C. echinata), $1 \mathrm{sn} / \mathrm{sh}, \mathrm{d}$. PALAU. Off Koror (hosted by Ctenactis albitentaculata, C. crassa, C. echinata, H. limax, S. robusta), $53 \mathrm{sn} / \mathrm{sh}+23 \mathrm{e}, 10 \mathrm{~d}$.

Type locality. Unknown.

Shell (figs 34-35, 94, 112; table 1). Most shells are coiled relatively tightly (figs $34-35$ ), but some are almost completely scalaroid as in Surrepifungium oliverioi (figs 36-37). For dimensions and number of costal and spiral ribs on the $2^{\text {nd }}$ and the $5^{\text {th }}$ teleoconch whorls, see table 1. A new maximum shell height of $44 \mathrm{~mm}$ was recorded in a sample collected off SW Sulawesi, Indonesia. The protoconch (fig. 94) has $3 \frac{1}{4}-3 \frac{1}{2}$ whorls $(n=10)$; apart from its smooth apical part, it is sculptured with regularly spaced, very fine, incised, axial lines, 21-24 (mean $=22.5, \mathrm{n}=2)$ per $0.2 \mathrm{~mm}$ on protoconch whorl $2 \frac{1 / 4-23 / 4}{}$. A. Gittenberger et al. (2000) reported very weak spiral lines on the teleoconch whorls. Such spiral lines are distinct on the $1^{\text {st }}$ and $2^{\text {nd }}$ teleoconch whorl (fig. 94) only, usually becoming obsolete from the $4^{\text {th }}$ whorl onwards $(n=20)$; they are not discernible on the $5^{\text {th }}$ whorl (fig. 112).

Operculum (fig. 136). Operculum paucispiral, with interconnected coils as in Surrepifungium patamakanthini spec. nov. (fig. 3). At the outside of the operculum there are 16 wavy threads per $0.1 \mathrm{~mm}$ (n $=2$ ), running about perpendicular to the growth lines. These threads are divided into segments, which are convex towards the operculum edge.

Radula (figs 163-164, 184-185, 204-205; table 2). Two radular types were found in Surrepifungium costulatum. One in a specimen from Indonesia, (type 1) and the other one in a specimen from Palau (type 2). These two snails were found underneath the same coral species, i.e. Ctenactis echinata (Pallas, 1766), and their shells are indistinguishable. In both types the stem and the blade of each tooth are similar in width and merge gradually.

In type 1 (fig. 163), the innermost tooth (fig. 185, left) and the penultimate one (fig. 205) both have an inconspicuous, blunt, secondary cusp, which is absent in all other teeth. Starting from the innermost, smallest tooth, with a height of $0.065 \mathrm{~mm}$, the teeth gradually increase in size to twice that height, i.e. $0.130 \mathrm{~mm}$, up to the $7^{\text {th }}$ tooth, after which they gradually become smaller again until the ultimate, i.e. $23^{\text {rd }}$ tooth, which is $0.082 \mathrm{~mm}$ high (table 2). All teeth are attached to the radular plate along the bases up to the basal denticle.

In type 2 (fig. 164), the innermost tooth (fig. 184, left) has an inconspicuous, blunt, secondary cusp, which is absent in all other teeth. Starting from the innermost, smallest tooth, with a height of $0.030 \mathrm{~mm}$, the teeth gradually become elongated and very slender, increasing in size to almost seven times that height, i.e. $0.195 \mathrm{~mm}$, up to the penultimate tooth (fig. 204). After that the smaller, usually malformed, $0.120 \mathrm{~mm}$ high $21^{\text {st }}$ tooth follows (table 2 ). In some of the largest teeth, the bases of the stem become partly detached from the radular plate, just below the basal denticle.

Jaw (figs 226-227; table 2). The jaws associated with both the radular types are similar. The denticulate edge consists of three or four irregular rows of basally pitted, slender, acute denticles, best visible from the inside of the jaw (fig. 227). The denticles in the 


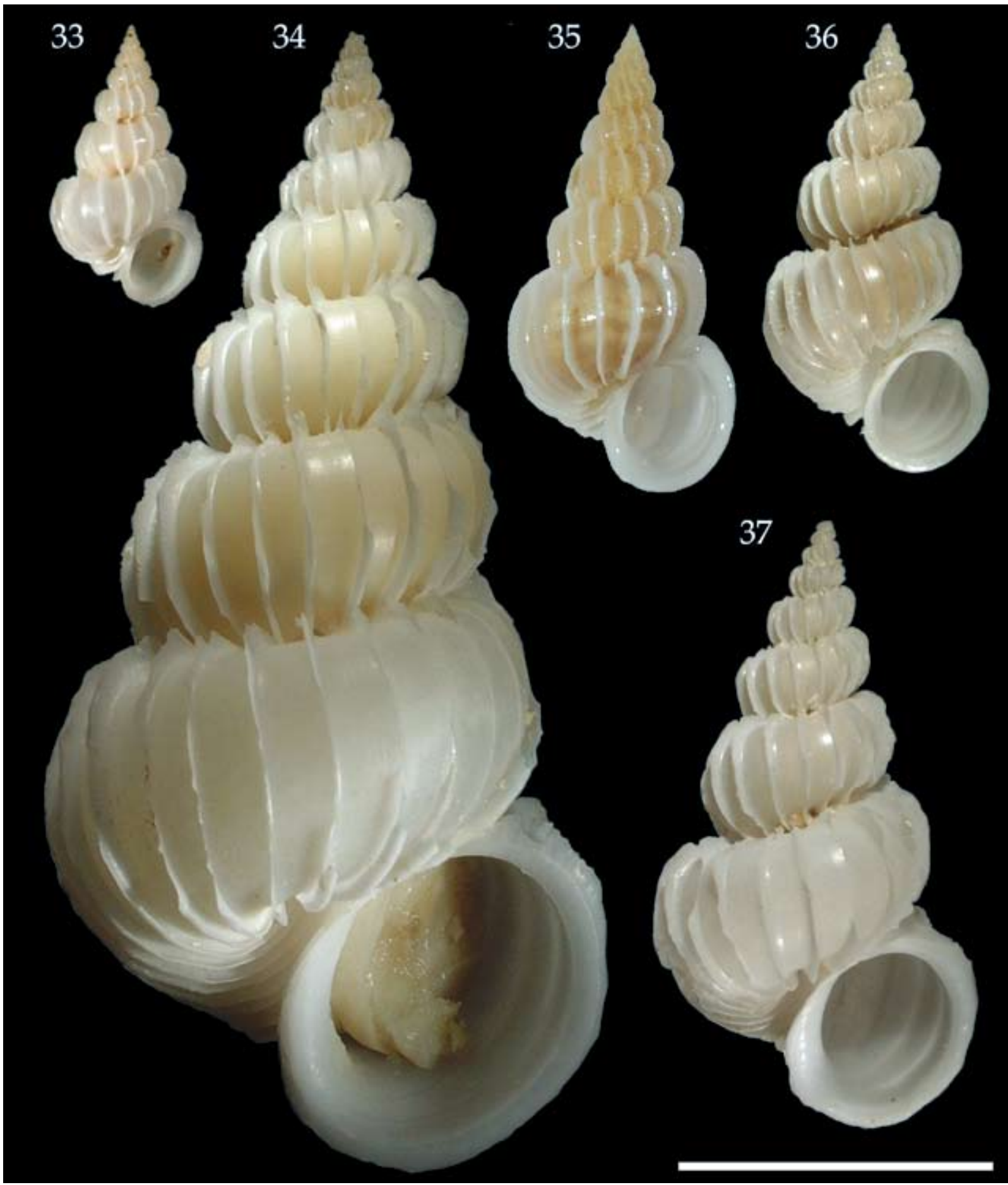

Figs 33-37. Shells. 33, 36-37, Surrepifungium oliverioi; 33, “Epitonium oliverioi”, paratype, Madagascar; 36, Egypt; 37, Thailand. 34-35, S. costulatum (Kiener, 1838), Palau. Scale bar $=1 \mathrm{~cm}$.

Figs 38-41. Shells. 38-39, Surrepifungium patamakanthini spec. nov.; 38, paratype, Maldives; 39, holotype, Palau. 40-41, S. ingridae, Palau. Scale bar $=1 \mathrm{~cm}$. 


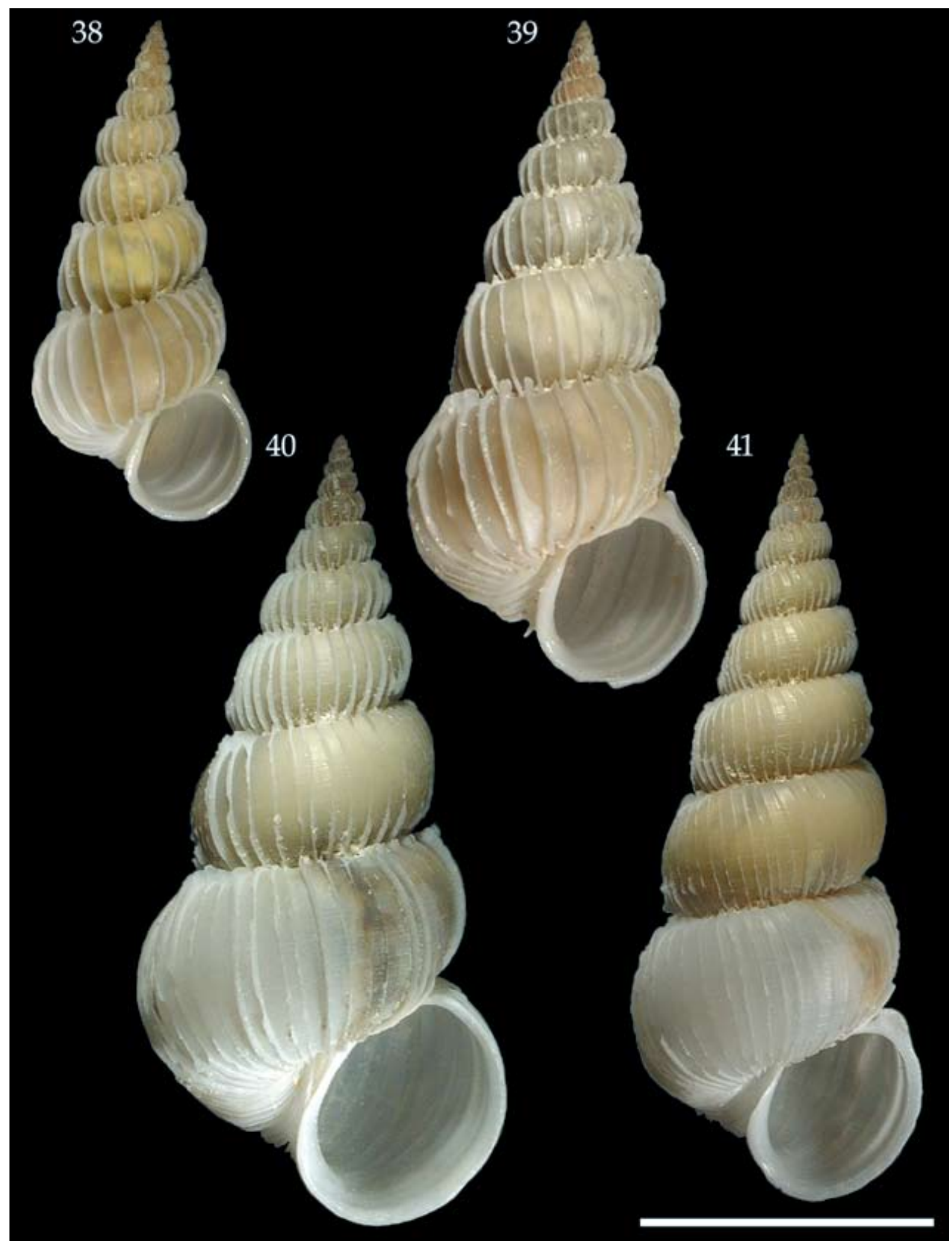


upper row are usually the largest ones, i.e. $0.020-0.030$ $\mathrm{mm}(\mathrm{n}=2)$ in height. Seen from the outside (fig. 226), 14-14 denticles per $0.05 \mathrm{~mm}(\mathrm{n}=2)$ extend above a $0.019-0.020 \mathrm{~mm}(\mathrm{n}=2)$ broad, relatively smooth to slightly granulated jaw-flap, which merges with the jaw along a zone with a distinct pattern of deeply sunken, pitted, irregular to pentagonal figures. Underneath the jaw-flap, a pattern of irregular to pentagonal figures quickly becomes obsolete. On the inner surface (fig. 227) no pattern is present.

Spawn (figs 264-265). The irregularly pentagonal, drop-shaped egg-capsules are covered with sand. They are 5.0-6.1 mm $($ mean $=5.3, \mathrm{n}=20)$ in diameter, e.g. measured horizontally, from left to right in figure 264, and contain 70-345 eggs (mean $=180, \mathrm{n}$ =10). A straight mucus thread (fig. 265), finely sculptured with longitudinal lines, connects the eggcapsules along their bases (on the left in fig. 264).

Habitat. The snails and their egg-capsules were found at 3-38 m, associated with Ctenactis albitentaculata Hoeksema, 1989, C. crassa (Dana, 1797), C. echinata (Pallas, 1766), Herpolitha limax (Esper, 1797), Sandalolitha robusta (Quelch, 1886) and S. dentata Quelch, 1884. These mushroom coral species occur both on sand and on a more solid substratum, but the snails with the egg-capsules were found on or in the sand (sometimes buried) only.

Distribution (fig. 42). The species is known from the Indo-West Pacific, from Egypt (Red Sea), Maldives, Thailand, Palau and Indonesia to NE Australia. The authors studied material from various localities (fig. 42), relying on data from the literature for the records from the Red Sea (Dushane, 1988a: 30-32), Philippines (Robertson, 1963: 57-58) and Australia (Loch, 1982: 4).

Differentiation. Shells of this species most closely resemble those of Surrepifungium oliverioi (Bonfitto and Sabelli, 2001) and S. patamakanthini spec. nov. See the differentiation of those species for details.

Remarks. For a photograph of the holotype, a more detailed description of the shell and the proboscis, and a comparison with Epitonium pallasii (Kiener, 1838), see A. Gittenberger et al. (2000). Here some additional data are given, with notes that may be relevant for the differentiation of this species. See also the remarks on $S$. oliverioi.

Surrepifungium ingridae (A. Gittenberger and Goud, 2000)

Epitonium ingridae A. Gittenberger and Goud, 2000: 7, 8, figs 7-8, 23-24, 27, 30.

Material. INDONESIA (hosted by Ctenactis echinata, Fungia (Fungia) fungites, F. (Verrillofungia) repanda, Sandalolitha robusta). SW Sulawesi, Spermonde archipelago, holotype (hosted by $F$. (F.) fungites): RMNH 59088, 6 paratypes $+5 \mathrm{e}$ : RMNH 59090-59093, 11 sn/sh+5e, 4d, 2r. MALAYSIA. East Malaysian peninsula, Tioman and Perhentian islands (hosted by $F$. (F.) fungites, S. robusta), 10sn/sh+3e, 5d. PALAU. Off Koror (hosted by Ctenactis albitentaculata, C. crassa, C. echinata, F. (F.) fungites, F. (V.) repanda, S. robusta), $40 \mathrm{sn} / \mathrm{sh}+19 \mathrm{e}, 10 \mathrm{~d}$.

Type locality. INDONESIA. SW Sulawesi, Spermonde archipelago.

Shell (figs 40-41, 95, 113). Shell shapes vary between broad and relatively slender conical (figs 40-41; shell height/width index in table 1). For dimensions and number of costal and spiral ribs on the $2^{\text {nd }}$ and the $5^{\text {th }}$ teleoconch whorls, see table 1 . A new maximum shell height of $27 \mathrm{~mm}$ (fig. 40) was recorded in a sample collected off Koror, Palau. The protoconch (fig. 95) has $23 / 4-3$ whorls $(n=10)$; apart from its smooth apical part, it is sculptured with regularly spaced, very fine, incised, axial lines, 25-26 $($ mean $=25.3, \mathrm{n}=3)$ per 0.2 $\mathrm{mm}$ on protoconch whorl $1 \frac{3 / 4}{-2}-\frac{1}{4}$.

Operculum (fig. 137). Operculum paucispiral, with interconnected coils as in Surrepifungium patamakanthini spec. nov. (fig. 3). At the outside of the operculum there are $14-16$ wavy threads per $0.1 \mathrm{~mm}$ $($ mean $=15.0, \mathrm{n}=4)$, running about perpendicular to the growth lines. These threads are divided into segments, which are convex towards the operculum edge.

Radula (figs 166, 186, 206, table 2). Two radulae could be studied (table 2). The stem and the blade of each tooth are similar in width and merge gradually. All teeth (fig. 166) are attached to the radular plate along the bases up to the basal denticle. The two innermost teeth (fig. 186) and the two outermost ones 
(fig. 206) usually have an inconspicuous, acute to blunt, secondary cusp each, which is absent in all other teeth. Starting from the innermost, smallest tooth, with a height of $0.016-0.021 \mathrm{~mm}(\mathrm{n}=2)$, the teeth gradually increase in size to about seven times that height, i.e. $0.124-0.142 \mathrm{~mm}(\mathrm{n}=2)$, up to the $13^{\text {th }}-14^{\text {th }}$ tooth, after which they gradually become smaller again until the ultimate, i.e. $20^{\text {th }}-21^{\text {st }}$ tooth, which is 0.061-0.062 mm $(\mathrm{n}=2)$ high (table 2).

Jaw (figs 228-230; table 2). The denticulate edge consists of three to five irregular rows of basally pitted, slender, acute denticles, best visible from the inside of the jaw (figs 228-229). The denticles in the upper row are usually the largest ones, i.e. 0.021$0.022 \mathrm{~mm}(\mathrm{n}=2)$ in height. Seen from the outside (figs 228-230), 19-20 denticles per $0.05 \mathrm{~mm}(\mathrm{n}=2)$ extend above a $0.040-0.052 \mathrm{~mm}(\mathrm{n}=2)$ broad, relatively smooth (fig. 228) to vaguely vertically sculptured (fig. 230) jaw-flap, which merges with the jaw along a zone with a distinct pattern of deeply sunken, pitted, irregular to pentagonal figures. Underneath the jaw-flap, a pattern of sunken, pentagonal figures gradually becomes obsolete (figs 228-229). On the inner surface (fig. 228) no pattern is present.

Spawn (figs 266-267). The irregularly pentagonal, drop-shaped egg-capsules are covered with sand. They are 3.4-3.9 $\mathrm{mm}($ mean $=3.6 \mathrm{~mm}, \mathrm{n}=20)$ in diameter, e.g. measured horizontally, from left to right in figure 266, and contain 93-173 eggs ( mean $=120$, $\mathrm{n}=8$ ). A straight mucus thread (fig. 267), finely sculptured with longitudinal lines, connects the eggcapsules along their bases (on the left in fig. 266).

Habitat. The snails and their egg-capsules were found at 1-26 m, associated with Ctenactis albitentaculata Hoeksema, 1989, C. crassa (Dana, 1797), C. echinata (Pallas, 1766), Fungia (Fungia) fungites (Linnaeus, 1758), F. (Verrillofungia) repanda Dana, 1846, Heliofungia actiniformis (Quoy and Gaimard, 1833), Sandalolitha robusta (Quelch, 1886). One dead specimen was found underneath Polyphyllia talpina (Lamarck, 1801). These mushroom coral species occur both on sand and on a more solid substratum, but the snails with the egg-capsules were found on or in the sand (sometimes buried) only.
Distribution (fig. 43). The species is known from the West Pacific, from the west of Peninsula Malaysia and Indonesia to Palau.

Differentiation. Shells of this species most closely resemble those of Surrepifungium patamakanthini spec. nov. They differ most clearly in having 20-31 $($ mean $=24, \mathrm{n}=5)$ costal ribs on the $5^{\text {th }}$ teleoconch whorl instead of 13-20 $($ mean $=16.1, \mathrm{n}=23)$, and by a radula with more than 19 , instead of 12 teeth in half a row. For comparisons with the epitoniid species Epitonium dubium Sowerby, 1844, E. friabilis (Sowerby, 1844), Scalaria grayi Nyst, 1871 and Foliaceiscala barissa Iredale, 1936, see A. Gittenberger et al. (2000).

Remarks. For a more detailed description of the shell and the proboscis, see A. Gittenberger et al. (2000). Here some additional data are given, with notes that may be relevant for the differentiation of this species.

Surrepifungium oliverioi (Bonfitto and Sabelli, 2001)

Epitonium oliverioi Bonfitto and Sabelli, 2001: 269.

Material. EGYPT. Red Sea, $350 \mathrm{~km} \mathrm{~S}$ of Hurghada (hosted by Herpolitha limax), 9sn+e, 2d. MADAGASCAR. Nosy Vé Island (hosted by Fungia cf(Verrillofungia) repanda), 3 paratypes: MZB 14026-14027 + "Paratype 4" as in Bonfitto and Sabelli (2001: 270) MALDIVES. Ari Atoll, off Vilamendhoo Island (hosted by H. limax), 2sh, 1sn+e, o, 2d. THAILAND. Krabi, Phiphi Islands (hosted by $H$. limax), $1 \mathrm{sn}+\mathrm{e}$. INDONESIA. Bali (hosted by Fungia (Fungia) fungites), 1sn+e. PALAU. Off Koror (hosted by $S$. robusta and $H$. limax), $8 \mathrm{sn}+3 \mathrm{e}$.

Type locality. MADAGASCAR. Nosy Vé Island.

Shell (figs 33, 36-37, 49, 97, 115). Most shells are almost scalaroid (figs 36-37), but some are coiled relatively tightly (fig. 33) as in Surrepifungium costulatum (figs 34-35). For dimensions and number of costal and spiral ribs on the $2^{\text {nd }}$ and the $5^{\text {th }}$ teleoconch whorls, see table 1. A new maximum shell height of $20.1 \mathrm{~mm}$ was recorded in a sample collected off Koror, Palau. The protoconch (fig. 97) has $3 \frac{114-31 / 2}{2}$ whorls $(n=10)$; apart from its smooth apical part, it is sculptured with regularly spaced, very fine, incised, axial lines, $25(\mathrm{n}=1)$ per $0.2 \mathrm{~mm}$ on protoconch 


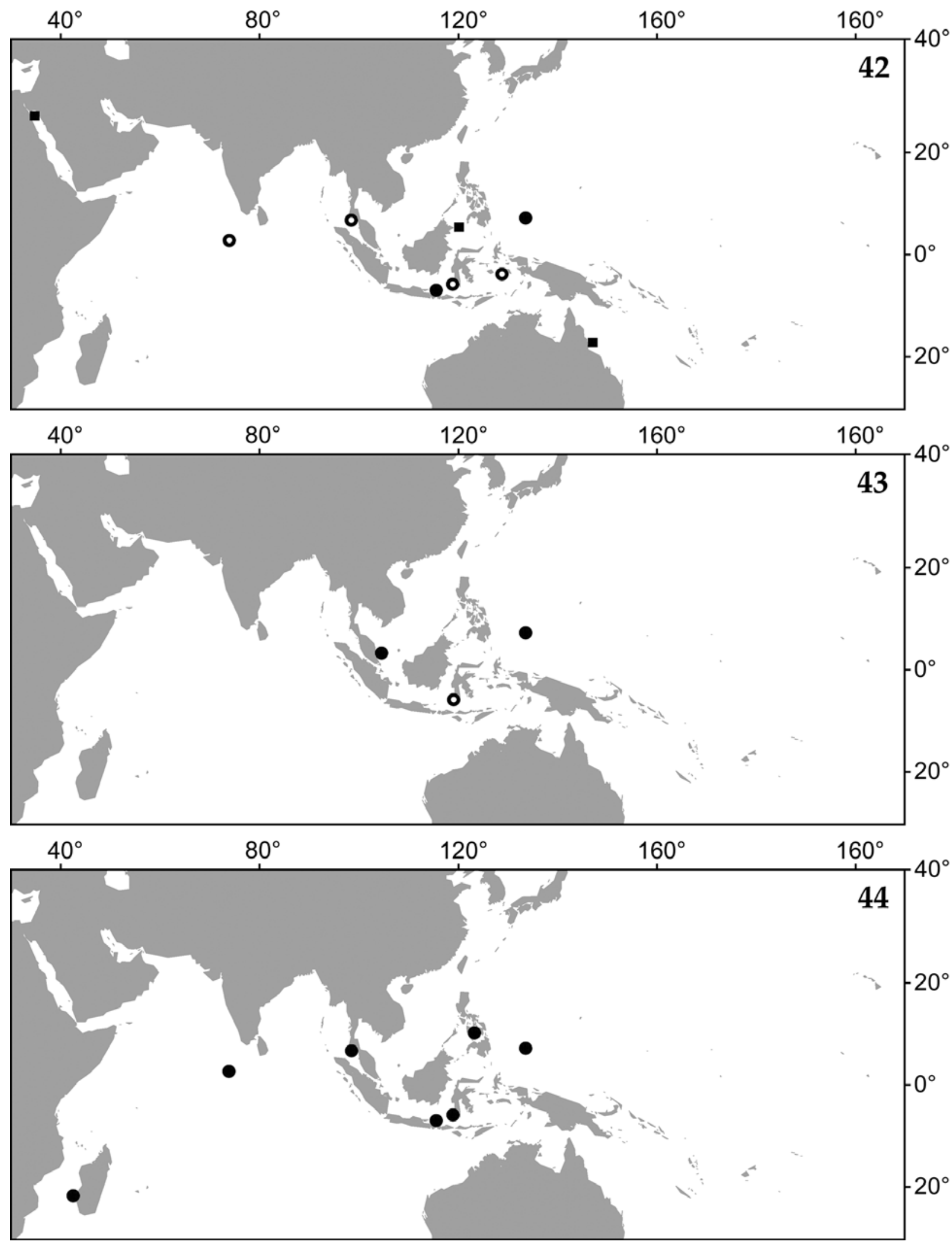




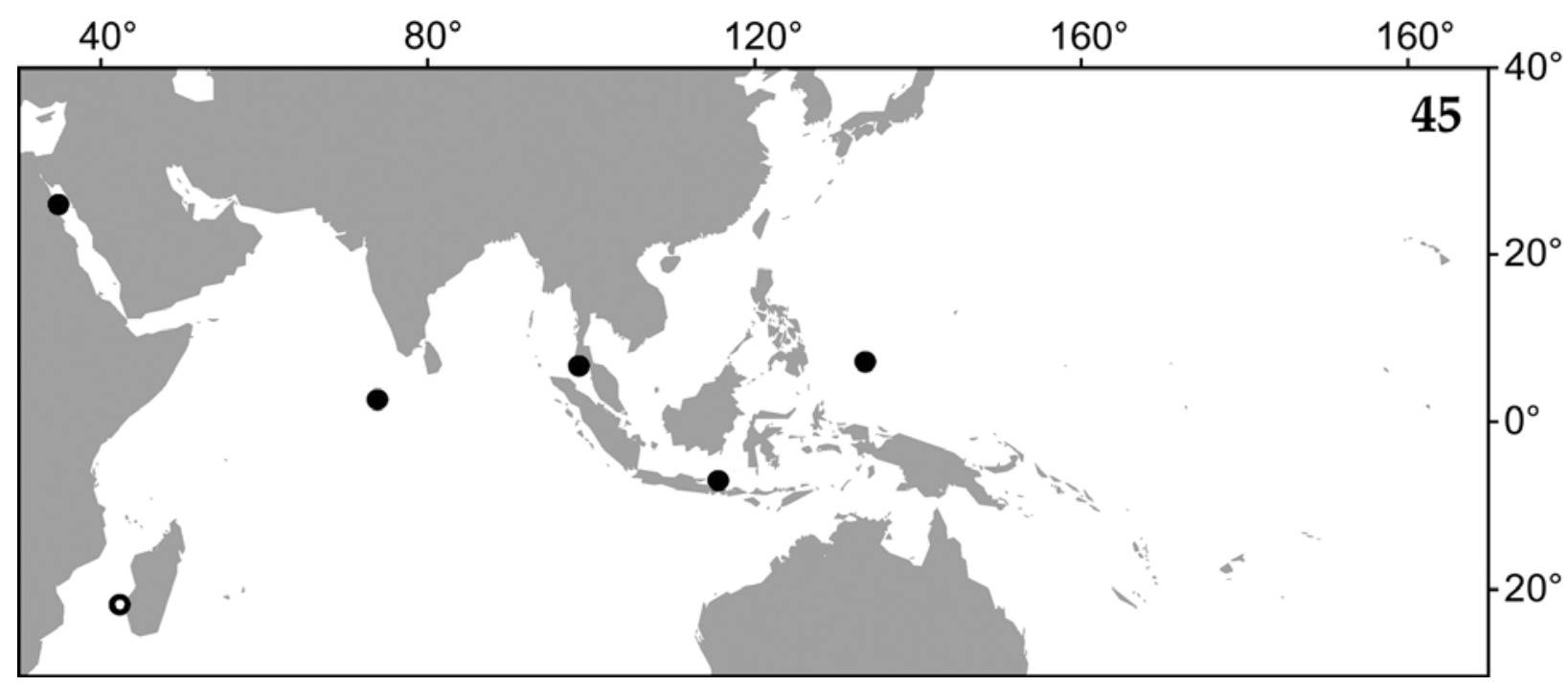

Fig. 45. The Indo-Pacific region, from the Red Sea to the Hawaiian archipelago, with the range of Surrepifungium oliverioi. New records (dots) and personally studied material (circles).

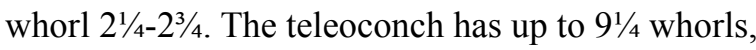
separated by a very deep suture, sometimes scalaroid from about the $7^{\text {th }}$ teleoconch whorl onwards; it is sculptured with mostly regularly placed, orthocline, lamellar, moderately high costae, which are usually continuous on the first six teleoconch whorls only. Although damaged costae may seem somewhat coronate (fig. 115), clearly undamaged ones do not have a coronation (fig. 49). Most costae were badly broken in all specimens studied. The teleoconch is additionally sculptured with very low, inconspicuous, regularly spaced, spiral threads on the initial whorls (fig. 97), becoming obsolete from about the $4^{\text {th }}$ teleoconch whorl onwards (fig. 115). Aperture subcircular. There is a distinct umbilicus.

Operculum (fig. 139). Operculum paucispiral, with interconnected coils as in Surrepifungium patamakanthini spec. nov. (fig. 3). At the outside of the operculum there are 20 wavy threads per $0.1 \mathrm{~mm}(\mathrm{n}=1)$, running about perpendicular to the growth lines. These threads are divided into segments, which are convex towards the operculum edge.

Figs 42-44. The Indo-Pacific region, from the Red Sea to the Hawaiian archipelago, illustrating Surrepifungium species ranges. New records (dots) and previously published records (squares = based on photographs only; circles = personally studied material); 42, Surrepifungium costulatum; 43, S. ingridae; 44, S. patamakanthini spec. nov.
Radula (figs 165, 188, 208; table 2). Three radulae could be studied, i.e. of a female (found while laying egg-capsules) and a probable male snail (smaller individual found together with this female) from Palau, and a female from the Maldives. The stem and the blade of each tooth are similar in width and merge gradually. The innermost tooth (fig. 188, left) has an inconspicuous, blunt, secondary cusp, which is absent in all other teeth. Starting from the innermost, smallest tooth, with a height of $0.030-0.049 \mathrm{~mm}$ (mean = $0.037, \mathrm{n}=3$ ), the teeth gradually become elongated and very slender, increasing in size to about five times that height, i.e. $0.135-0.227 \mathrm{~mm}($ mean $=0.184, \mathrm{n}=$ 3 ), up to usually the penultimate tooth (fig. 208). After that the smaller, usually malformed, ultimate, 0.053-0.175 $\mathrm{mm}$ high $18^{\text {th }}-22^{\text {nd }}$ tooth follows (table 2). In some of the largest teeth, the bases of the stem become partly detached from the radular plate, just below the basal denticle.

Jaw (figs 234-235; table 2). Only one pair of jaws was studied (table 2). The denticulate edge consists of two or three rows of basally scarcely pitted, slender, somewhat drop-shaped, acute denticles, best visible from the inside of the jaw (fig. 235). The denticles in the upper row are usually the largest ones, i.e. up to 0.008 $\mathrm{mm}$ in height. Seen from the outside, 16 denticles per $0.05 \mathrm{~mm}$ extend above a $0.012 \mathrm{~mm}$ broad, relatively smooth to slightly granulated jaw-flap, which merges 
with the jaw along a zone with a distinct pattern of deeply sunken, pitted, pentagonal figures. Underneath this zone, no distinct pattern is present. On the inner surface (fig. 235) no pattern is present.

Spawn (figs 270-271). The irregularly pentagonal, drop-shaped egg-capsules are covered with sand. They are 2.5-3.5 mm $($ mean $=3.2, \mathrm{n}=10)$ in diameter, e.g. measured horizontally, from left to right in figure 270, and contain 135-160 eggs (mean $=149$, n =10). A straight mucus thread (fig. 271), finely sculptured with longitudinal lines, connects the eggcapsules along their bases (on the left in fig. 270).

Habitat. The snails and their egg-capsules were found at 4-38 m depth, associated with Fungia (Fungia) fungites (Linnaeus, 1758), F. cf (Verrillofungia) repanda Dana, 1846, Herpolitha limax (Esper, 1797) and Sandalolitha robusta (Quelch, 1886). These mushroom coral species occur both on sand and on a more solid substratum, but the snails with the egg-capsules were found on or in the sand (sometimes buried) only.

Distribution (fig. 45). The species is known from the Indo-West Pacific, from Egypt (Red Sea), Madagascar, Maldives and Indonesia to Palau.

Differentiation. Conchologically this species most closely resembles Surrepifungium costulatum (figs 34-35). The radula of $S$. oliverioi is similar to the "type 2" radula of $S$. costulatum (see the description of that species; figs 164, 184, 204). Furthermore the DNA-sequences (Cytochrome Oxidase I) found for eight $S$. costulatum and four $S$. oliverioi specimens are very similar and therefore not diagnostic (A. Gittenberger et al., in prep.). In general, the species can be distinguished by their shells, which are usually somewhat more loosely coiled in S. oliverioi (figs 36-37) than in S. costulatum (figs 34-35) and by their egg-capsule sizes, which are $2.5-3.5 \mathrm{~mm}$ in $S$. oliverioi versus 5.0-6.1 $\mathrm{mm}$ in $S$. costulatum. These differences may also represent intraspecific variation, suggesting that $S$. oliverioi and $S$. costulatum are conspecific. Surrepifungium costulatum however, is the only species that was found to have two types of radula. This may indicate the presence of an additional, cryptic species instead of a dimorphism within the species. If so, a name may be available already. Because of this uncertainty, Surrepifungium costulatum and S. oliverioi are here still considered separate species. Future analyses of additional molecular markers and the jaws of a larger number of specimens, can resolve this issue. Shells of $S$. oliverioi also resemble those of $S$. patamakanthini spec. nov., but differ in having solely "single" (figs 97, 115) instead of fused lamellate costae (figs 96, 114) on the initial teleoconch whorls, in not having distinct coronations on the costae (figs 49-50), in having a spiral sculpture becoming obsolete from $\mathrm{c}$. the $4^{\text {th }}$ instead of the $6^{\text {th }}$ teleoconch whorl (figs 114-115) on. Specimens of $S$. oliverioi can also be distinguished from $S$. patamakanthini spec. nov. by their radulae with about 20 (fig. 165) instead of 12 teeth (fig. 167) in half a row.

Remarks. The description given above has to differ from that by Bonfitto and Sabelli (2001), because some paratypes were found to be not conspecific with the holotype. Three paratypes were studied. Their heights are 17.0, 15.8 and $9.1 \mathrm{~mm}$ (fig. 33). They correspond with paratypes 1 (MZB 14026), 2 (MZB 14027) and 4 (BMNH ?) in Bonfitto and Sabelli (2001). Paratype 1 (MZB 14026) was identified as Surrepifungium patamakanthini spec. nov. (fig. 50). The other two paratypes were found to be conspecific with the holotype. The description and photograph of the holotype in Bonfitto and Sabelli (2001) indicate that it is $19 \mathrm{~mm}$ in height and has 19 costal ribs on the body whorl. Two $S$. oliverioi specimens from Thailand and Palau, with shell heights of 19.2 $\mathrm{mm}$ (fig. 37) and $20.1 \mathrm{~mm}$, have 19 and 20 ribs respectively on the body whorl and therefore resemble the holotype. In S. patamakanthini (figs 38-39) however, the shells have at least 21 costal ribs on the body whorl at a height of 16-19 mm, i.e. 21-25 costal ribs (mean $=22.6, \mathrm{n}=15$ ). Paratype 1 (fig. 50) of "Epitonium oliverioi" that was identified as S. patamakanthini also falls within this range, with a shell height of $17.0 \mathrm{~mm}$ and 21 ribs.

\section{Surrepifungium patamakanthini spec. nov.}

Material. Samples that were hosted by Ctenactis echinata, $C$. crassa, Sandalolitha robusta, Heliofungia actiniformis, Fungia (Fungia) fungites, F. (Danafungia) horrida, F. (Verrillofungia) concinna and $F$. (V.) repanda are coded $\mathrm{Ce}, \mathrm{Cc}, \mathrm{Sr}, \mathrm{Ha}, \mathrm{Ff}, \mathrm{Fh}$, $\mathrm{Fc}$ and Fr, respectively. PALAU. SW Ubelsechel, $\mathrm{N}$ of Toachel 
Ra Ngel (07¹7'50'N 134²9'08'E), holotype RMNH 95373 Ff/1sh, with egg-capsules RMNH 100220; paratypes: type locality, RMNH 95374 Ff/1sn, 1sh; SW Ubelsechel, N Toachel Ra Ngel (07¹8'03”N 134²9'44'E), RMNH 95376 Fr/1sn+e; S Ubelsechel, NE Toachel Re Ngel (07¹8'28'N 134'30'23'E), RMNH 95375 Sr/3sh+e, 3o, r; E Koror, SW Ngeream, patch reef in KB channel $\left(07^{\circ} 20^{\prime} 22^{\prime \prime} \mathrm{N} 134^{\circ} 31^{\prime} 05^{\prime \prime} \mathrm{E}\right), \mathrm{RMNH} 95363 \mathrm{Fc} / 1+\mathrm{e}$; $\mathrm{N}$ of Ngeremdiu, Lighthouse reef, backreef, $\left(07^{\circ} 17^{\prime} 11^{\prime \prime} \mathrm{N}\right.$ $\left.134^{\circ} 27^{\prime} 26^{\prime \prime} \mathrm{E}\right), \mathrm{RMNH} 95364 \mathrm{Ff} / 1 \mathrm{sn}+\mathrm{e}$; NE of Ngeremdiu, Lighthouse reef, forereef $\left(07^{\circ} 16^{\prime} 30^{\prime \prime} \mathrm{N} 134^{\circ} 27^{\prime} 25^{\prime \prime} \mathrm{E}\right), \mathrm{RMNH} 95369$ $\mathrm{Cc} / 1 \mathrm{sh}, 95370 \mathrm{Ce} / 1 \mathrm{sn}+\mathrm{e}, 95365 \mathrm{Fc} / 1 \mathrm{sn}, 95372 \mathrm{Ff} / 1 \mathrm{sn}$; NE of Ngeremdiu, Lighthouse reef, forereef ( $\left.07^{\circ} 16^{\prime} 47^{\prime \prime} \mathrm{N} 134^{\circ} 27^{\prime} 50^{\prime \prime} \mathrm{E}\right)$, RMNH 95371 Ff/1sn; NE of Ngeremdiu, Lighthouse reef, forereef, sandy slope $\left(07^{\circ} 16^{\prime} 14^{\prime \prime} \mathrm{N} 134^{\circ} 27^{\prime} 21^{\prime \prime E}\right)$, RMNH 95379 $\mathrm{Cc} / 1 \mathrm{sh}+\mathrm{e}, 95380 \mathrm{Cc} / 2 \mathrm{sh}+\mathrm{e}, \mathrm{d}, 95381 \mathrm{Cc} / 1 \mathrm{sh}, \mathrm{r}, \mathrm{d}, 95382 \mathrm{Ff} / 2 \mathrm{sh}+\mathrm{e}$, o, 2d, 95378 Ff/1sn+e; S of Ngeremdiu, Rael Dil, backreef (07 $\left.15^{\prime} 04^{\prime \prime} \mathrm{N} 134^{\circ} 27^{\prime} 02^{\prime \prime} \mathrm{E}\right), \mathrm{RMNH} 95366 \mathrm{Ff} / 1 \mathrm{sn}$. MADAGASCAR. Nosy Vé Island, paratype of Surrepifungium oliverioi: MZB 14026, 1sh from Fungia cf repanda. MALDIVES. Ari Atoll, Vilamendhoo Island: House reef, $\left(03^{\circ} 38^{\prime} \mathrm{N} 72^{\circ} 57^{\prime} \mathrm{E}\right), \mathrm{RMNH}$ $100216 \mathrm{Fr} / 2 \mathrm{sn}+\mathrm{e}, 100217 \mathrm{Fh} / 1 \mathrm{sh}$, o, d. THAILAND. Southern Phuket Islets, RMNH 100218 1sn, host unknown; Krabi, Phiphi Islands: Ko Bida Nok (07³9'14’N 9845'58'E), RMNH 95906 Ce/1sn+e, d; SE Ko Bida Nai (07³9'27'N 98³7'38'E), RMNH $95893 \mathrm{Ce} / 1 \mathrm{sn}+\mathrm{e}$. PHILIPPINES. Cebu Strait: Cabilao Island (off Bohol), La Estrella Resort, RMNH 100219 Ha/1sh. INDONESIA. SW Sulawesi, Spermonde archipelago, SW Kudingareng Keke Island (05'06'21"S 119 17'03”'E), RMNH 95295 Ff/2sn, 1sh, d. Bali: Tanjung Benoa, Loloan Benoa (08 43'31'S 115'15'57'E), RMNH 95247 Fr/1sn+e; SE Tulamben beach, Drop-off (0816'40”S 115³5'45’'E), RMNH 95249 Fh/1sn+e.

Type locality. PALAU. SW Ubelsechel, $\mathrm{N}$ of Toachel Ra Ngel (07¹7'50'N 134²9'08'E).

Shell (figs 38-39, 50, 96, 114; table 1). Shell (figs 38-39) fragile, moderately elongated conical, with convex whorls, creamy white; reaching $22.8 \mathrm{~mm}$ in height. For dimensions and number of costal and spiral ribs on the $2^{\text {nd }}$ and the $5^{\text {th }}$ teleoconch whorls, see table 1 . The holotype (fig. 39) measures 22.8 $\times 10.4 \mathrm{~mm}$. The protoconch (fig. 96) has $3 \frac{1 / 4-31 / 2}{1}$ whorls $(\mathrm{n}=10)$; apart from its smooth apical part, it is sculptured with regularly spaced, very fine, incised, axial lines, $23(\mathrm{n}=1)$ per $0.2 \mathrm{~mm}$ on protoconch whorl $2 \frac{1}{4}-2^{3} / 4$. The teleoconch (figs $38-39,50,114$ ) has up to $11 \frac{1}{2}$ whorls, separated by a very deep suture; it is sculptured with mostly regularly placed, orthocline, lamellar, moderately high costae, which are usually continuous on the initial teleoconch whorls only. Costae touching the adjoining whorls and usually curving adaperturally at the preceding whorl. Shortly before the preceding whorl is reached, the costae increase abruptly in height, forming a distinct coronation (fig. 114). Initial whorls usually with multiple, lamellate costae, which are fused to form broader ones (figs 96,114). The number of costae on the initial five teleoconch whorls remains approximately the same, i.e. about 16 ribs per whorl (table $1)$; it only increases on the younger whorls, with 21$25($ mean $=22.6, n=15)$ costal ribs on the $8^{\text {th }}-10^{\text {th }}$ teleoconch whorl in shells with a height of $16-19 \mathrm{~mm}$, and even up to 46 costae on the $10^{\text {th }}$ whorl in a shell of $21.0 \mathrm{~mm}$ in height. The teleoconch is additionally sculptured with very low, inconspicuous, randomly placed, spiral threads (figs 96, 114), which become obsolete from about the $6^{\text {th }}$ teleoconch whorl onwards. Aperture subcircular. There is a narrow but distinct umbilicus.

Operculum (figs 3-5, 138). Operculum paucispiral, with interconnected coils (fig. 3). At the outside of the operculum (fig. 138) there are 9-10 wavy threads per $0.1 \mathrm{~mm}(\mathrm{n}=2)$, running about perpendicular to the growth lines. These threads are divided into segments, which are convex towards the operculum edge. Except for the muscle scar and growth lines, no micro-sculpture was found on the inside of the operculum. The muscle scar is irregular, varying from a roughly dotted surface to a relatively smooth, densely dotted or striped surface (fig. 5).

Radula (figs 6-7, 13, 167, 187, 207; table 2). Three radulae could be studied, i.e. from a snail from the Maldives and two snails from Palau. The stem and the blade of each tooth are similar in width and merge gradually (fig. 13). All teeth (fig. 167) are attached to the radular plate along the bases up to the basal denticle. The innermost tooth (fig. 187, left) in a row has an inconspicuous, pointed, secondary cusp, which is absent in all other teeth. Starting from the innermost, smallest tooth, with a height of 0.030-0.037 $\mathrm{mm}($ mean $=0.033, \mathrm{n}=3)$, the teeth quickly increase in size to about four times that height up to the $3^{\text {rd }}$ tooth, after which they gradually become somewhat larger still, up to the largest, $0.150-0.171 \mathrm{~mm}$ (mean $=0.159, \mathrm{n}=3$ ) high tooth, which is either the penultimate or the ultimate one, i.e. the $12^{\text {th }}$. In two radulae, the ultimate tooth was c. $0.050 \mathrm{~mm}$ smaller, i.e. $0.102-0.126 \mathrm{~mm}$ high, than the $0.150-0.171 \mathrm{~mm}$ high penultimate one. In the third radula the ultimate tooth was slightly larger, i.e. $0.155 \mathrm{~mm}$, than the penultimate one, i.e. $0.153 \mathrm{~mm}$ (table 2). 
Jaw (figs 6-7, 231-233; table 2). The denticulate edge consists of three to five irregular rows of basally pitted, slender, acute denticles, best visible from the inside (figs 232-233). The denticles in the upper row are usually the largest ones, i.e. $0.020-0.022 \mathrm{~mm}$ (mean $=0.021, \mathrm{n}=3$ ) in height. At the outside (fig. 231), 16-18 denticles per $0.05 \mathrm{~mm}$ (mean $=17, \mathrm{n}=$ $3)$ extend above a $0.020 \mathrm{~mm}(\mathrm{n}=1)$ broad, densely pitted jaw-flap, which merges with the jaw along a zone with a pattern of slightly raised, scarcely pitted, irregular to pentagonal figures. Underneath the jawflap, a vague pattern of pentagonal figures quickly becomes obsolete. On the inner surface (fig. 232) no pattern is present.

Spawn (figs 268-269). The irregularly pentagonal, drop-shaped egg-capsules are covered with sand. They are 2.7-3.1 mm $($ mean $=2.9, \mathrm{n}=10)$ in diameter, e.g. measured horizontally, from left to right in figure 268, and contain 280-480 eggs (mean $=382.2$, $\mathrm{n}=10$ ). A straight mucus thread (fig. 269), finely sculptured with longitudinal lines, connects the eggcapsules along their bases (on the left in fig. 268).

Habitat. The snails and their egg-capsules were found at 5-18 m, associated with Ctenactis echinata (Pallas, 1766), C. crassa (Dana, 1846), Sandalolitha robusta (Quelch, 1886), Heliofungia actiniformis (Quoy and Gaimard, 1833), Fungia (Fungia) fungites (Linnaeus, 1758), F. (Danafungia) horrida Dana, 1846, F. (Verrillofungia) concinna Verrill, 1864 and $F$. (V.) repanda Dana, 1846 . These mushroom coral species occur both on sand and on a more solid substratum, but the snails with the egg-capsules were found on or in the sand (sometimes buried) only.

Distribution (fig. 44). The species is known from the Indo-West Pacific, from Madagascar, Maldives, Thailand, Philippines and Indonesia to Palau.

Differentiation. Conchologically and in habitat preference, this species resembles Surrepifungium costulatum, $S$. oliverioi and $S$. ingridae. It differs from these three species in having 12 instead of more than 17 radular teeth in half a row (table 2). It can furthermore be distinguished from $S$. costulatum and $S$. oliverioi by the presence of fused lamellae forming thick costal ribs on the initial whorls and the coronations on the ribs. It differs from $S$. ingridae in having
13-20 (mean $=16.1, \mathrm{n}=23)$ costae instead of 20-31 $($ mean $=24, \mathrm{n}=5)$ costae on the $5^{\text {th }}$ teleoconch whorl (see table 1) and by the lack of a distinct spiral sculpture from about the $6^{\text {th }}$ teleoconch whorl onwards.

Etymology. This species is named in appreciation of Mr Somnuk Patamakanthin, for his hospitality at the Phuket Shell Museum and the donation of specimens of Surrepifungium costulatum and S. patamakanthini from Thailand.

\section{Epitonium Röding, 1798, s.l.}

Type species. Turbo scalaris L., 1758 (design.: Suter, 1913: 319).

New species. Pending additional data, the following two species are provisionally classified in Epitonium, calling attention to these forms by describing, illustrating and naming them.

Epitonium crassicostatum spec. nov.

Material (hosted by Fungia (Cycloseris) costulata). INDONESIA. Bali, Sanur, Jeladi Willis, S of channel entrance (08'40'59"S $115^{\circ} 16^{\prime}$ 03”E), holotype RMNH 100214/1sh.

Type locality. INDONESIA. Bali, Sanur, Jeladi Willis, S of channel entrance (0840'59'S $\left.115^{\circ} 16^{\prime} 03^{\prime \prime} \mathrm{E}\right)$.

Shell (figs 48, 98, 116; table 1). Shell fragile, elongate-conical, with convex whorls, white. The holotype (figs $48,98,116$ ) measures $4.8 \times 2.2 \mathrm{~mm}$. The protoconch, broken in the holotype, has at least $2 \frac{1}{4}$ whorls; it is sculptured with regularly spaced, very fine, incised, axial lines, 22 per $0.2 \mathrm{~mm}$ on the penultimate protoconch whorl. The teleoconch has up to at least $5 \frac{1}{2}$ whorls, separated by a moderately deep suture. Teleoconch sculptured with multiple, lamellate costae, which are fused to form thicker ones. The number of lamellate costae that are connected to form a thicker costal rib, increases gradually from two on the $1^{\text {st }}$ teleoconch whorl (fig. 98) to six on the $6^{\text {th }}$ whorl (fig. 116). Eleven orthocline, continuous, regularly placed, thick costal ribs per whorl are fused together with the ribs on the adjoining whorls (figs $48,116)$. All costae have a small coronation just above the centre of the whorl (fig. 116). On the initial 

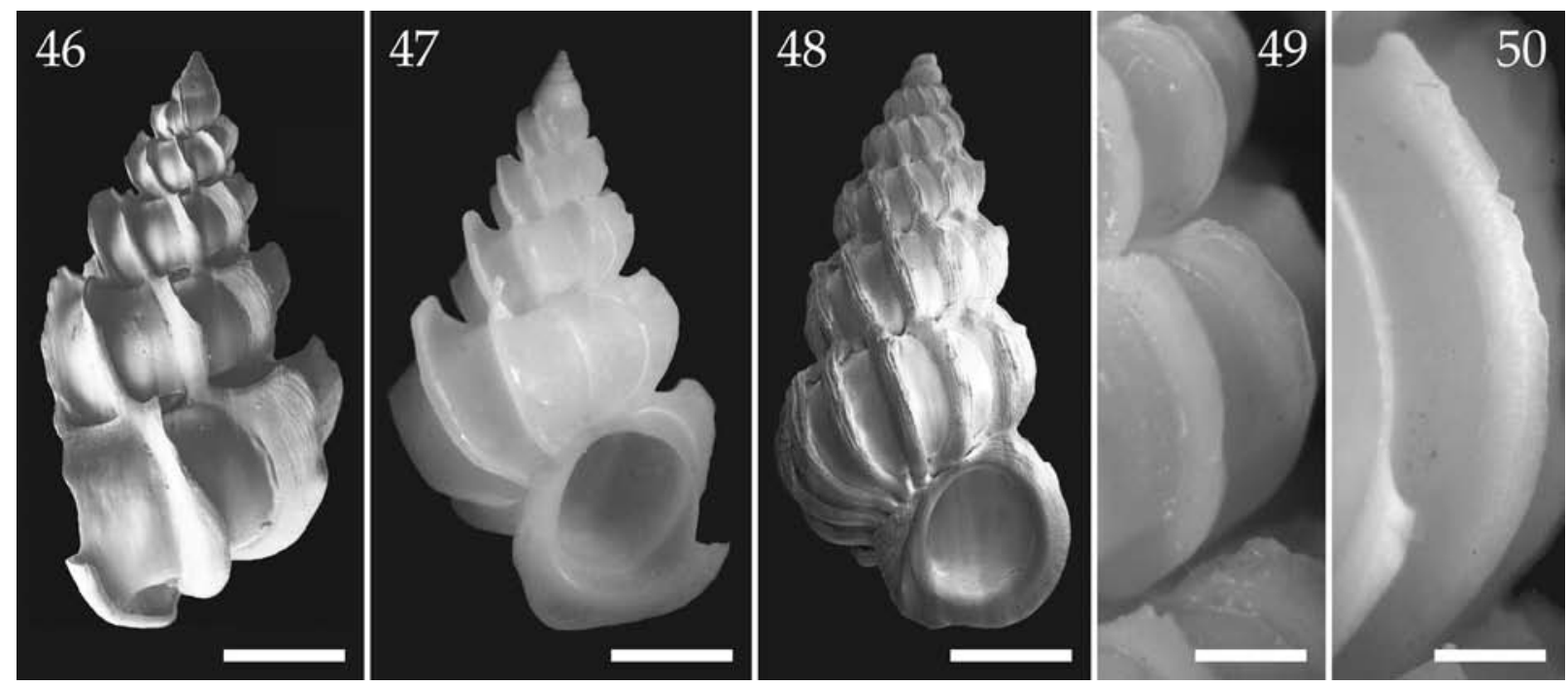

Figs 46-50. Shells. 46-47, Epitonium graviarmatum spec. nov., holotype, Maldives. 48, Epitonium crassicostatum spec. nov., holotype, Bali, Indonesia. 49-50, "Epitonium oliverioi", paratypes, Madagascar; 49, Surrepifungium oliverioi, detail costal rib on $5^{\text {th }}$ teleoconch whorl; 50, Surrepifungium patamakanthini spec. nov., paratype, not $S$. oliverioi, detail costal rib on $6^{\text {th }}$ teleoconch whorl. Scale bars: $46-48=1 \mathrm{~mm} ; 49-50=0.5 \mathrm{~mm}$. Photos: through binoc. $(46,48-49)$ and with SEM, using uncoated material $(45,47)$.

teleoconch whorls the spiral threads are obsolete. From the $3^{\text {rd }}$ whorl onwards, about 17 , very low, spiral threads become discernible. Aperture subcircular, its columellar margin relatively thick, formed by a fusion of several lamellae. Apertural height / shell height $=0.27$. Umbilicus closed.

Operculum, Radula, Jaw and Spawn. Unknown.

Habitat. One empty shell was found on sand beneath the mushroom coral Fungia (Cycloseris) costulata Ortmann, 1889, at a depth of $9 \mathrm{~m}$.

Distribution. Off Jeladi Willis, Sanur, Bali, Indonesia.

Etymology. Crassicostatum is composed after "crassi", Latin for "thick", and "costatum", Latin for "having ribs".

Differentiation. This species differs from all other epitoniids in the position of the coronations on the costae, just above the periphery of the whorls. A similar sculpture of an increasing number of fused lamellate costae, forming thick costal ribs up to at least the $6^{\text {th }}$ teleoconch whorl, has also been found in some specimens of Surrepifungium ingridae (fig.
113; A. Gittenberger et al., 2000: 8, figs 23-24, 27) and S. patamakanthini spec. nov. (fig. 114).

Remarks. The shell height could not be measured accurately because of the missing protoconch whorls. Therefore the indexes based on this height, cannot be accurate either. This species could also be classified with Surrepifungium gen. nov., because of the fused, lamellate, thick costal ribs and its association with a fungiid coral.

\section{Epitonium graviarmatum spec. nov.}

Material (hosted by Fungia (Cycloseris) vaughani). Maldives. Ari Atoll, Vilamendhoo island, $\left(03^{\circ} 38^{\prime} \mathrm{N} 72^{\circ} 57^{\prime} \mathrm{E}\right)$, holotype RMNH 100215/1sh.

Type locality. MALDIVES. Ari Atoll, Vilamendhoo island, $\left(03^{\circ} 38^{\prime} \mathrm{N} 72^{\circ} 57^{\prime} \mathrm{E}\right)$.

Shell (figs 46-47, 99, 117; table 1). Shell fragile, conical, with convex whorls, white with a thin, dark, purple line along the upper margin of the initial four protoconch whorls. The holotype (figs 46-47, 99, 117 ) measures $4.8 \times 2.9 \mathrm{~mm}$. The protoconch (fig. 99) has 5 whorls; it is sculptured from c. the $1^{\text {st }}$ whorl onwards with regularly spaced, very fine, incised, 
axial lines, 20 per $0.2 \mathrm{~mm}$ on protoconch whorl $3 \frac{3 / 4-}{4}$ $4 \frac{1 / 4}{4}$, and from about the $2^{\text {nd }}$ whorl onwards with regularly spaced, very fine, incised, spiral lines, 7 per $0.1 \mathrm{~mm}$ on protoconch whorl $33 / 4-4 \frac{1}{4} 4$. The teleoconch (fig. 117) has up to four whorls, separated by a deep suture; each whorl is sculptured with eight, regularly placed, continuous, orthocline, lamellar, very high costae. Costae fusing with or only touching the costae on the adjoining whorls (fig. 117). Shortly before the preceding whorl is reached, the costae increase abruptly about five times in height, forming a large coronation. On both sides of a costal rib, up to five, evenly placed, fine lines, run parallel to the margin (fig. 117). No spiral sculpture is present on the teleoconch. Aperture subcircular. Apertural height / shell height $=0.31$. Umbilicus closed.

Operculum, Radula, Jaw and Spawn. Unknown.

Habitat. One empty shell was found, on the sandy substratum, underneath the mushroom coral Fungia (Cycloseris) vaughani Boschma, 1923, at a depth of $35 \mathrm{~m}$.

Distribution. Off Vilamendhoo island, Maldives.

Etymology. Graviarmatum is composed after "gravi", Latin for "heavily", and "armatum", Latin for "defensively armed".

Differentiation. This species resembles Epitonium alatum (Sowerby, 1844). It differs from the holotype (Dushane, 1987a: 1, fig. 3) and the descriptions and photographs in Dushane (1987a: 1, 4, figs 3-4) and Weil et al. (1999: 90-91, fig. 272) in having much higher costal ribs and 5 instead of 2 protoconch whorls. The epitoniid identified as E. alatum by Nakayama (2003: 48, figs 22-24) closely resembles this species, but is described as having minute spiral striae in between the costae. Such striae are missing in E. graviarmatum spec. nov., which seems to have less than 4, instead of 5 protoconch whorls. In $E$. alatum specimens there is an open umbilicus (Dushane, 1987a: 4; Weil et al., 1999: 90; Nakayama, 2003: 48 ) instead of a closed one.

Remarks. This species might in fact belong to Surrepifungium gen. nov., because of the lack of a spiral sculpture on the teleoconch and its association with a fungiid coral.
Epidendrium gen. nov.

Type species. Epidendrium sordidum spec. nov.

Other species. Scalina billeeana Dushane and Bratcher, 1965; Epitonium dendrophylliae Bouchet and Warén, 1986; Epidendrium sordidum spec. nov.

Shell (table 1). The fragile shells have a distinct teleoconch sculpture of low, costal ribs and spiral threads. Among the four Epidendrium gen. nov. species the shell shapes vary between very broad and relatively slender conical (figs 1, 51-57; table 1; Bouchet and Warén, 1986: 522, figs 1217, 1218). Both slender and broad shells were found in samples collected from the same host. Both forms were found laying egg-capsules, so that the variation cannot be explained by differences in sex.

Operculum. Except for growth lines, no micro-sculpture is present on the outside of the opercula of Epidendrium aureum spec. nov. and $E$. sordidum spec. nov. The opercula of E. billeeanum and E. dendrophylliae could not be studied.

Soft parts. The animal is yellowish, with small, dark eyespots.

Radula (table 2). All single teeth have an acute apical cusp, and no to seven secondary cusps; an inconspicuous basal denticle is absent on the innermost, and present on the outermost teeth within a row (figs 160-162, 182-183, 202-203; Dushane and Bratcher, 1965: 24, fig. 3a-b; Page and Willan, 1988: 224-225, figs 2-3; Richter and Luque, 2004: 100, fig. 1c-d).

Jaw (table 2). The denticulate jaw-edge consists of a single row of slender to lamellar denticles (figs 29, 237-241). Underneath these denticles, a prominent jaw-flap lies loosely on the outer surface of the jaw, partly covering the pattern there (figs 236-237, 240-242).

Spawn. Oval, yellowish, slightly transparent eggcapsules with protuberances (figs 272, 274), connected by a straight (figs 273, 275) to twisted (like fig. 299; Oliverio et al., 1997: 8, figs 14-15) mucus thread. The uncleaved eggs are $0.077 \mathrm{~mm}(\mathrm{n}=10$ / species) in diameter. The eggs and egg-capsules of 
Epidendrium billeeanum and E. dendrophylliae could not be studied. The development from eggs to veligers in the egg-capsules of $E$. aureum spec. nov. resembles that described for $E$. hartogi by A. Gittenberger (2003: 147, fig. 42); no data are available for E. billeeanum, E. dendrophylliae and E. sordidum spec. nov.

Habitat. The snails live on, or in the vicinity of their dendrophylliid host corals (Scleractinia: Dendrophylliidae).

Etymology. The name Epidendrium is composed after "epi", Greek for "on", and "dendrium", referring to the coral host family "Dendrophylliidae". The gender is neuter, i.e. with the ending "ium".

Differentiation. A similar teleoconch sculpture of distinct low costal ribs and spiral threads is present in some Epifungium gen. nov. species, e.g. E. hoeksemai, E. lochi and E. pseudolochi spec. nov. (figs 104-105, 108, 124-125, 128), and in Epitonium species, e.g. E. striatissimum (Monterosato, 1878) (Bouchet and Warén, 1986: 522, fig. 1216). The relatively large range in the shell height/width indexes within Epidendrium gen. nov. species, is uncommon in epitoniids, but also present in the coral-associated species Epifungium hoeksemai (figs 75-76), E. ulu (figs 70-72) and Surrepifungium ingridae (figs 40-41).

The lack of an operculum sculpture of threads, running about perpendicular to the growth lines, distinguishes this genus, or at least Epidendrium aureum spec. nov. (figs 132-133) and E. sordidum spec. nov. (fig. 134), from the other two epitoniid genera that are associated with corals, viz. Epifungium gen. nov. (figs 140-151) and Surrepifungium gen. nov. (figs 136-139). Epitonium pyramidalis (fig. 135) also lacks this sculpture.

Similar radular teeth are present in all epitoniid genera studied, viz. in Cirsotrema (figs 152, 195), Epifungium gen. nov. (189-194, 209-214), Epitonium (figs 178-180, 198-200), Gyroscala (figs 181, 201) and Surrepifungium gen. nov. (figs 184-188, 204-208). In Janthina janthina (fig. 16) (Janthinoidea Lamarck, 1810 [=Epitoniacea Berry, 1910], Janthinidae) similar teeth as in Epidendrium aureum spec. nov. occur, but these can be about twenty times larger.

The jaws, with a single row of denticles and a jaw- flap (figs 236-242), closely resemble those of Epifungium gen. nov. species (figs 11, 243-263); they differ from other epitoniid genera, like Cirsotrema (figs 10, 215), Epitonium (figs 218-225), Gyroscala (figs 216-217) and Surrepifungium gen. nov. (figs 226-235), in denticle form, the presence of a jaw-flap, and/or the number of denticle rows.

The oval, slightly transparent egg-capsules, with protuberances, are also known from several Epifungium gen. nov. species, which are usually found on the surface of their coral host, viz. E. adgranulosa spec. nov. (fig. 276), E. hartogi (fig. 282), E. hoeksemai (fig. 284), E. nielsi spec. nov. (fig. 290) and $E$. $u l u$ (fig. 298). Most epitoniids live on and in the sand however, and have drop-shaped, oval or round capsules, which are covered with sand and do not have any protuberances, e.g. Cirsotrema varicosa, several Epifungium gen. nov. species (figs 278, 280, 286, 288, 292), Epitonium ancillottoi, E. clathrus (in Vestergaard, 1935) and species of Surrepifungium gen. nov. (figs 164, 266, 268, 270).

The habitat seems not to be shared with any other epitoniid species.

Remarks. Because specimens of the two Indo-West Pacific species Epidendrium aureum spec. nov. and E. sordidum spec. nov. were repeatedly confused with the East Pacific Epitonium billeeanum Dushane and Bratcher, 1965, the data presented on allegedly that species by several authors (Debelius, 1996a; Debelius, 1996b; A. Gittenberger, 2003; Loch, 1982; Oliverio et al., 1997; Robertson and Schutt, 1984; Page and Willan, 1988) should be treated with care.

Page and Willan (1988) concluded that snails of $E$. billeeanum from the Great Barrier Reef, Australia, change sex between 8.6 and $12.7 \mathrm{~mm}$ shell length, and that their radulae go through an ontogenetic change while doing so. The two radula-types that are described for males and females of E. billeeanum, are similar to those of $E$. sordidum spec. nov. and $E$. aureum spec. nov., respectively. Probably Page and Willan (1988) have misidentified their specimens as E. billeeanum, a species that, according to our data, only occurs in the East Pacific. Shells of E. sordidum spec. nov. and E. aureum spec. nov. often occur sympatrically, in large numbers, on the same host colony. In general the shells of E. sordidum spec. nov. are smaller than those of E. aureum spec. nov., explaining the association Page and Willan (1988) 
found between shell size and radular type. See also the remarks on E. aureum spec. nov.

\section{Epidendrium aureum spec. nov.}

Scalina billeeana Dushane and Bratcher, 1965: Oliverio et al., 1997: 3-10, figs 1-21; Robertson and Schutt, 1984: 4, 2 figs; Debelius, 1996a: 150-151, 2 figs; Debelius, 1996b: 72-73, figs 1-6; A. Gittenberger, 2003: 140-144, figs 3, 13, 20, 28-32. Not Scalina billeeana Dushane and Bratcher, 1965.

Material (all hosted by Tubastrea or Dendrophyllia species). PALAU. W Ulong, W of barrier reef, Tsey's tunnel ( $07^{\circ} 18^{\prime} 40^{\prime \prime} \mathrm{N}$ 134¹3'30"E), holotype RMNH 95287/1sh; paratypes: type locality, RMNH 95286/6sn; W Babelthuap, Toachel Mlengui, North side of West Passage (07³2'31'N 134²8'24'E), RMNH 95288/2sn, d; E Babelthuap, E of Arudowaishi Pt., Uchelbeluu reef, backreef ( $07^{\circ} 18^{\prime} 40^{\prime \prime} \mathrm{N} 134^{\circ} 13$ '30”E), RMNH 95284/1sh, 95285/1sn; SW Ngerchaol, N of entrance Malakal Harbor, Beduliases, (07020'12'N 134²6'10'E), RMNH 95283/1sn; NE Ngeremdiu, Lighthouse reef, forereef (07 16 '30'N 134 $27^{\circ} 25^{\prime}$ 'E), RMNH 95282/1sn+e. EGYPT. Off Marsa Shagra, about $300 \mathrm{~km}$ S of Hurghada, RMNH 95241/1sn, r, 95242/1sn, 95243/1sn, 95244/3sn, d; Off Marsa Nakari, about 350 S of Hurghada, RMNH 95245/19sn+e, d. SEYCHELLES. E of Mahé, near

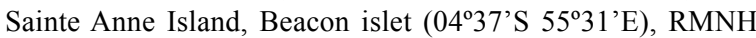
100199/1sn. MALDIVES. Ari Atoll, Vilamendhoo Island: House reef, (033'스 72 $57^{\circ}$ 'E), RMNH 100197/2sn, d, 100196/2sn+e, d, 100178/1sn, 100177/1sn, 100337/1sn. THAILAND. Krabi, Phiphi Islands: Hin Mu Sang, Shark point Phuket (07\%48'17'N 97³7'38”E), RMNH 95885/1sn, d; Ko Bida Nok, (07³9'14”N 98\%45'58'E), RMNH 95905/11sn, d, 95998/2sn; Hin Daeng (0708'59”N 98\%49'25”E), RMNH 95980/7sn+e, r. PHILIPPINES. Cebu Strait, W Bohol: Cabilao Island, La Estrella Resort, RMNH 100179/8sn, d; W Cabilao Island, S-side fish sanctuary (0952'37'N 12345'38'E), RMNH 83485/23sn+e, d; S Cabilao Island, Cabacungan Point (0951'30'N 12345'57'E), RMNH $83486 / 1$ sh, 15 sn, r, d. INDONESIA. NE Kalimantan, Berau Islands, N lighthouse- 1 reef, S of Derawan Island ( $02^{\circ} 16^{\prime} 02^{\prime \prime} \mathrm{N}$ $118^{\circ} 14^{\prime 2} 3^{\prime \prime E), ~ R M N H ~ 100175 / 1 s n . ~ N ~ S u l a w e s i: ~ S e l a t ~ L e m b e h, ~}$ between Tanjungnanas and Teluk Kungkungan $\left(01^{\circ} 28^{\prime} \mathrm{N}\right.$ 12515'E), RMNH 100195/4sh, 13sn+e, d, 100194/14sn; N Lembeh Strait, W Lembeh Island (0130'01'N 125'15'39'"E), RMNH 100203/3sn+e; Off Manado, Bunaken: (01'36'23”N 12446'59'E), RMNH 100176/1sn, 100204/3sn+e; (01 39'09'N $\left.124^{\circ} 42^{\prime} 17^{\prime \prime E}\right)$, RMNH $100206 / 1 \mathrm{sn}+\mathrm{e} ;\left(01^{\circ} 36^{\prime} 45^{\prime \prime} \mathrm{N}\right.$ $\left.124^{\circ} 44^{\prime} 22^{\prime \prime E}\right)$, RMNH 100205/1sn+e; (01 $37^{\circ} 50^{\prime \prime} \mathrm{N}$ 124\%46'14"E), RMNH 100201/2sn+e, 100202/1sn; (01'37'10'N 124\%46'55”E), RMNH 100207/1sn. SW Sulawesi, Spermonde archipelago: SW Samalona Island (0507'42”S 119 20'31'E), RMNH 95238/1sn+e, r, 95240/1sh; W Kudingareng Keke Island (0506'09'S 119¹7'9'E), RMNH 95233/1sn, r, d; W Badi Island (04'58'05"S 119 16'54”E), RMNH 95235/18sn+e, 95236/4sn+e, 95237/1sn; NW Bone Tambung Island ( $05^{\circ} 02^{\prime} 05^{\prime \prime} \mathrm{S}$ 119¹6'16”E), RMNH 95234/1sn. Sulawesi, Wakatobi National Park, Karang Kapota NW, outer reef, RMNH 100198/1sh, d. Komodo: Selat Linta, NE Pulau Tatawa (08³0'39"S 119³8'36”E), RMNH 95289/4sn+e; S of Tanjung Toro Langkoi, Manta Ally (0844'12”S 119²4'42”'E), RMNH 95290/6sn; Gili Lawa Laut, 100200/6sn. Bali: E Nusa Dua, Off Club Med Hotel, N of channel (0847'06'S $115^{\circ} 13^{\prime}$ '57'E), RMNH 95227/2sn, 95228/2sn+e, 1sh, r, 95229/1sn; NW Nusa Penida, Toyapakeh (0840'56”'S 115²8'56”E), RMNH 95232/1sn+e. AUSTRALIA. Western Australia, Shark Bay, Cleft Bernier I, South of Carnarvon (2445'32'S $113^{\circ} 09^{\prime} 57^{\prime}$ 'E), WAM/2sh.

Type locality. PALAU. W Ulong, W of barrier reef,

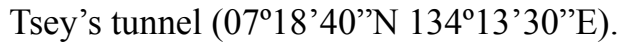

Shell (figs 51-52, 92, 118; table 1). The shell height/ width indexes vary considerably (table 1), resulting in shells varying from broad-conical (fig. 52) to relatively slender-conical (fig. 51). Shell (figs 51-52) fragile, with convex whorls; reaching $20.1 \mathrm{~mm}$ in height. For dimensions and number of costal and spiral ribs on the $2^{\text {nd }}$ and the $5^{\text {th }}$ teleoconch whorls, see table 1 . The holotype (fig. 51) measures $20.1 \times$ $10.7 \mathrm{~mm}$. The protoconch is entirely coloured with a dark, purplish red pigment, which continues on the teleoconch whorls, where this colouring is most conspicuous below the periphery, gradually fading out and not visible anymore from about the $5^{\text {th }}$ teleoconch whorl onwards. The remaining parts of the teleoconch are white to yellowish. The protoconch (fig. 92) has 31/4-31/2 whorls $(n=10)$; apart from its smooth apical part, it is sculptured with regularly spaced, very fine, incised, axial lines, 21 $22($ mean $=21.7, \mathrm{n}=3)$ per $0.2 \mathrm{~mm}$ on protoconch whorl $2 \frac{1 / 4}{4}-2 \frac{3}{4}$. The teleoconch (figs $51-52,118$ ) has up to $83 / 4$ whorls, separated by a moderately deep suture; it is sculptured with mostly regularly placed, discontinuous, orthocline, lamellar, not or slightly curved, low costae, not or hardly touching the adjoining whorls. The number of costae on the $2^{\text {nd }}$, $3^{\text {rd }}, 5^{\text {th }}$ and younger teleoconch whorls usually increases quickly, up to 164 costae on the $7^{\text {th }}$ whorl in a shell of $12.0 \mathrm{~mm}$ in height. The teleoconch is additionally sculptured with regularly placed, relatively thick, spiral threads. The number of prominent spirals on the $2^{\text {nd }}, 3^{\text {rd }}, 5^{\text {th }}$ teleoconch whorls slowly increases, usually remaining approximately the same from the $6^{\text {th }}$ whorl onwards; there are up to 35 spirals on a whorl. The lamellar costae increase slightly in height when running over the spiral threads. Aperture subcircular. There is a moderately wide umbilicus. 
Operculum (figs 132-133). Operculum paucispiral. The coils are either interconnected, as in Surrepifungium patamakanthini spec. nov. (fig. 3), or scalaroid (see A. Gittenberger, 2003: 142, fig. 22). Except for growth lines, no micro-sculpture (figs 132-133) is discernable on the outside of the opercula $(n=4)$.

Radula (figs 160-161, 183, 203; table 2). Three radulae could be studied, i.e. one from a snail from Thailand and two from Indonesian snails. The stem and the blade of each tooth are similar in width and merge gradually. All teeth (figs 160-161) are attached to the radular plate along the bases up to the inconspicuous, small, basal denticle (fig. 203). The innermost tooth (fig. 183, left) in a row has an acute secondary cusp, which is absent in all other teeth. This secondary cusp is about half the size of the apical cusp. Starting from the innermost, smallest tooth, with a height of 0.021-0.031 mm (mean $=0.027, \mathrm{n}$ $=3$ ), the teeth gradually become elongated and very slender, increasing in size to about four to five times that height, i.e. $0.119-0.143 \mathrm{~mm}($ mean $=0.130, \mathrm{n}=$ $3)$, up to the $13^{\text {th }}-21^{\text {st }}$ tooth $($ mean $=18.7, n=3)$, after which they gradually become smaller again until the ultimate, usually malformed, $0.042-0.086 \mathrm{~mm}$ (mean $=0.063, \mathrm{n}=3$ ) high $30^{\text {th }}-34^{\text {th }}$ tooth (table 2$)$.

Jaw (figs 22, 29, 236-238; table 2). The denticulate edge consists of a row of lamellar denticles (figs 22, 236-237), which are densely pitted basally, on the inside (fig. 238). They have a maximum size of $0.0048-0.0070 \mathrm{~mm}(\mathrm{n}=2)$. Seen from the outside (figs 22, 236-237), 38-46 denticles $(\mathrm{n}=2)$ per 0.05 $\mathrm{mm}$ extend above a $0.026-0.026 \mathrm{~mm}(\mathrm{n}=2)$ broad, granulated jaw-flap (fig. 22), which lies loosely over part of the jaw-pattern (figs 29, 236-237). This pattern, as far as visible under the jaw-flap, consists of two or three rows of somewhat sunken, densely pitted, pentagonal figures, followed further on by one or two rows of deeply sunken, scarcely pitted, pentagonal figures, and after that by more or less unclear rows of somewhat sunken, scarcely pitted, pentagonal to irregular figures that occasionally have holes (fig. 237; as in Epidendrium sordidum spec. nov., fig. 20). Away from the denticulate edge, the pattern gradually becomes obsolete (fig. 236). On the inner surface of the jaw (fig. 238), below the denticles, there are three to five rows of engraved, scarcely pitted, square-like figures, followed by an area that is somewhat granulated to smooth.
Spawn (figs 272-273). Egg-capsules (fig. 272) ovoid, yellowish, somewhat transparent, with conspicuous protuberances, not embedded with sand, 1.46-3.14 $\mathrm{mm}($ mean $=2.17, \mathrm{n}=8)$ in diameter, e.g. measured horizontally, from left to right in figure 272, containing 270-630 eggs $($ mean $=521.3, \mathrm{n}=8)$ each. The mucus threads that connect the egg-capsules, are either straight (fig. 273) or twisted (as in Epifungium hartogi, fig. 284; Oliverioi et al., 1997: 8, figs 14-15), and either smooth (fig. 273) or sculptured with longitudinal lines (as in Epidendrium sordidum spec. nov., fig. 275).

Habitat. The snails and their egg-capsules were found at 2-28 m, associated with Tubastrea and Dendrophyllia corals. They usually live on, or in the vicinity of their dendrophylliid hosts, attached to the surface of the substrate with mucus threads. The host corals occur most commonly fixed to the underside of large boulders, in crevices, on the ceilings of caves or on the steep walls of drop-offs. Shells of this species are often found together with those of Epidendrium sordidum spec. nov. with the same coral host colony.

Distribution (fig. 58). The species is known from the Indo-West Pacific, from the Red Sea, Seychelles, Maldives, Thailand, Japan, Philippines, Palau and Indonesia to West and East Australia. The authors studied material from various localities (fig. 58), relying on data from the literature for some of the records from the Red Sea (Oliverioi et al., 1997: 6-9, figs 1-8) and Australia (Page and Willan, 1988: 223, fig. 1). The species was observed, but not collected, by the first author in Japan, Okinawa, off Akajima island, and in NE Australia, off the $3^{\text {rd }}$ ribbon reef and off Osprey reef.

Differentiation. The shells of this species most closely resemble those of Epidendrium billeeanum Dushane and Bratcher, 1965. They differ in having a dark purplish red instead of a white to yellowish protoconch. Another difference concerns the radula. In E. aureum spec. nov. there is no distinct secondary cusp on the elongated, slender radular teeth, as was figured for E. billeeanum by Dushane and Bratcher (1965: pl. 24, fig. 3a). The largest teeth are the $12^{\text {th }}-22^{\text {th }}$ in half a row of $30-34$ teeth in E. aureum spec. nov. (table 2), while according to Dushane and Bratcher (1965: 161), the outermost radular teeth 
are the largest in E. billeeanum. Shells of E. aureum spec. nov. also resemble those of $E$. sordidum spec. nov.; they can easily be distinguished, however by the teleoconch sculpture of ribs that do not distinctly vary in height, instead of ribs that abruptly become two to three times higher, forming distinct protuberances, where running over the spiral threads.

Etymology. This species is named after its in situ brightly yellow colour, which gives it a golden hue.

Remarks. The morphological differences between shells of Epidendrium billeeanum from the type locality in Baja California, and the epitoniid species here described as $E$. aureum spec. nov. and $E$. sordidum spec. nov. from the Indo-West Pacific, were regarded as intraspecific variation in the literature, mainly because of the absence of sufficient material for study (e.g. Oliverio et al., 1997; Loch, 1982). With hundreds of specimens from the Red Sea, Maldives, Thailand, Philippines, Indonesia and Palau available, it became obvious that these shells from the Indo-West Pacific are consistently different from the 10 shells that were studied from Baja California. Thus, the commonly used vernacular name "Golden Wentletrap" refers to three species, i.e. E. aureum spec. nov., E. billeeanum and $E$. sordidum spec. nov. These findings and the data obtained by a DNA-analysis (A. Gittenberger et al., in prep.) convincingly show that the IndoWest Pacific specimens represent two species that are both new to science, viz. E. aureum spec. nov. and $E$. sordidum spec. nov. Although E. sordidum spec. nov. is only slightly less common than $E$. aureum spec. nov. and occurs sympatrically with it at most localities, recognizable photographs of golden wentletraps from the Indo-West Pacific, always show E. aureum spec. nov. This is probably because in E. aureum spec. nov. the shells are usually somewhat larger and not as dirty as in $E$. sordidum spec. nov. Golden wentletraps on photographs from the Galapagos islands (various internet sources), do not show pigmented protoconchs. Therefore, they are considered conspecific with E. billeeanum (fig. 56), which was also cited from the Galapagos islands by Dushane and Bratcher (1965: 161).
Epidendrium billeeanum (Dushane and Bratcher, 1965)

Scalina billeeana Dushane and Bratcher, 1965: 87-88.

Material (hosted by Tubastrea tenuilamellosa). MEXICO. Gulf of California, SW Cerralvo Island, holotype CAS 63823/1sh, BMNH paratype/1sh, RMNH 100427/8sn+e.

Type locality. MEXICO. Gulf of California, SW Cerralvo Island.

Shell (fig. 56). The fragile shell (fig. 56) is rather broad-conical and entirely white to yellowish, no distinction can be made between the colour of the protoconch and teleoconch; reaching $14.1 \mathrm{~mm}$ in height. For dimensions and number of costal and spiral ribs on the $2^{\text {nd }}$ and the $5^{\text {th }}$ teleoconch whorls of the holotype (fig. 56), see table 1 . The holotype measures $6.2 \times 4.0 \mathrm{~mm}$. The teleoconch is sculptured with mostly regularly placed, discontinuous, orthocline, lamellar, not or slightly curved, low costae, not or hardly touching the adjoining whorls, and regularly placed, relatively thick, spiral threads. The lamellar costae increase slightly in height when running over the spiral threads.

Operculum. Unknown.

Radula (table 2). Dushane and Bratcher (1965: pl. 24, fig. 3a-b) figured the c. $0.076 \mathrm{~mm}$ high, slender, elongated teeth of the holotype, which have either a single, acute or no secondary cusps (where these teeth are situated in a row is not indicated). According to Dushane and Bratcher (1965) the holotype has an indefinite number of these teeth, the outermost of which are the largest. Similar slender, elongated teeth without secondary cusps are known from Epidendrium aureum spec. nov. (fig. 203).

Jaw. Unknown.

Spawn. Egg-capsules (as in Epidendrium aureum and E. sordidum, figs 272, 274) ovoid, yellowish, somewhat transparent, with conspicuous protuberances, not embedded with sand, $2.45-2.60 \mathrm{~mm}$ (mean $=2.55$, $\mathrm{n}=2$ ) in maximum diameter, containing 403-470 eggs (mean $=436.5, \mathrm{n}=2$ ) each. The mucus threads that connect the egg-capsules, are twisted (as in 
Epifungium hartogi, fig. 284). The yellow "eggs" that are described by Dushane and Bratcher (1965: 161) are probably egg-capsules.

Habitat. The snails and their egg-capsules were found at about 2-4 m, under rocky ledges, attached to their dendrophylliid host corals, i.e. Tubastrea tenuilamellosa (Milne-Edwards and Haime, 1848), by mucus threads (Dushane and Bratcher, 1965).

Distribution. The species is known from the Gulf of California and the Galapagos archipelago.

Differentiation. See the differentiation of Epidendrium aureum spec. nov.

Remarks. For a more detailed description, see Dushane and Bratcher (1965). Here some additional data are given, with notes that may be relevant for the differentiation of this species. See also the remarks on Epidendrium aureum spec. nov.

Epidendrium dendrophylliae (Bouchet and Warén, 1986)

Epitonium dendrophylliae Bouchet and Warén, 1986: 502, 522523, figs 1175, 1217-1218; Richter and Luque, 2004: 99-101, fig. 1.

Material. SPAIN. Malaga, collection Frank Swinnen, 1sh.

Type locality. SPAIN, Madeira.

Shell (fig. 57). Shell shapes (table 1) vary between moderately broad (fig. 59; Bouchet and Warén, 1986: 522, fig. 1218) to relatively slender-conical (Bouchet and Warén, 1986: 522, fig. 1217) as is also found in e.g. Epidendrium aureum spec. nov. (figs 51-52) and E. sordidum spec. nov. (figs 53-55). The fragile shell is white to yellowish. For dimensions and number of costal and spiral ribs on the $2^{\text {nd }}$ and the $5^{\text {th }}$ teleoconch whorls of the specimen studied (fig. 57), see table 1. The protoconch of the holotype (Bouchet and Warén, 1986: 502, fig. 1175) has 31/4-31/2 whorls; apart from its smooth apical part, it is sculptured with regularly spaced, very fine, incised, axial lines, 25 per $0.2 \mathrm{~mm}$ on protoconch whorl $2 \frac{1 / 4}{4} 2^{3 / 4}$.

Operculum. Unknown.
Radula. The radular teeth as described and figured by Richter and Luque (2004: 99-100, fig. 1c-d) have two to six acute, secondary cusps. The apical cusp is about $1 \frac{1}{2}$ to 2 times larger than the secondary cusp(s) underneath it. The secondary cusps resemble each other in size.

Jaw. The denticulate jaws have a reticulate pattern on the surface (Richter and Luque, 2004: 99).

Spawn. Unknown.

Habitat. The snails are found on dendrophylliid corals. Although they usually occur deeper than $40 \mathrm{~m}$ and in association with the coral genera Dendrophyllia and Balanophyllia, Richter and Luque (2004) recorded one specimen from $19 \mathrm{~m}$ on Astroides calycularis (Pallas, 1766).

Distribution. The species is known from the eastern Atlantic and the western Mediterranean (Richter and Luque, 2004).

Differentiation (figs 1, 2). The shells resemble those of Epidendrium aureum spec. nov., E. billeeanum and E. sordidum spec. nov., but differ in having a closed instead of an open umbilicus, and by less costal ribs on the $2^{\text {nd }}, 3^{\text {rd }}$ and $5^{\text {th }}$ teleoconch whorl, i.e. 20,20 and 19 , respectively (table 1 ), and about 28 on the $5^{\text {th }}$ teleoconch whorl of the holotype (Bouchet and Warén, 1986: 522-523, fig. 1218), versus E. aureum spec. nov., $E$. billeeanum and $E$. sordidum spec. nov. with at least 25,29 and 30 ribs on the $2^{\text {nd }}, 3^{\text {rd }}$ and $5^{\text {th }}$ teleoconch whorls and usually many more (table 1 ). The radular teeth of $E$. dendrophylliae most closely resemble those of $E$. sordidum spec. nov. (figs 162, 182, 202), differing most clearly in having secondary cusps that resemble each other in size, instead of becoming gradually smaller down the blade of a tooth (fig. 202) and by a smaller apical cusp, which is $1 \frac{1}{2}-2$ instead of 2-3 times longer than the secondary cusp underneath it.

Remarks. For a detailed description and a comparison with Epitonium striatissimum (Monterosato, 1878) see Bouchet and Warén (1986) and Richter and Luque (2004). Here some additional data are given, with notes that may be relevant for the differentiation of this species. See also the remarks on Epidendrium aureum spec. nov. 


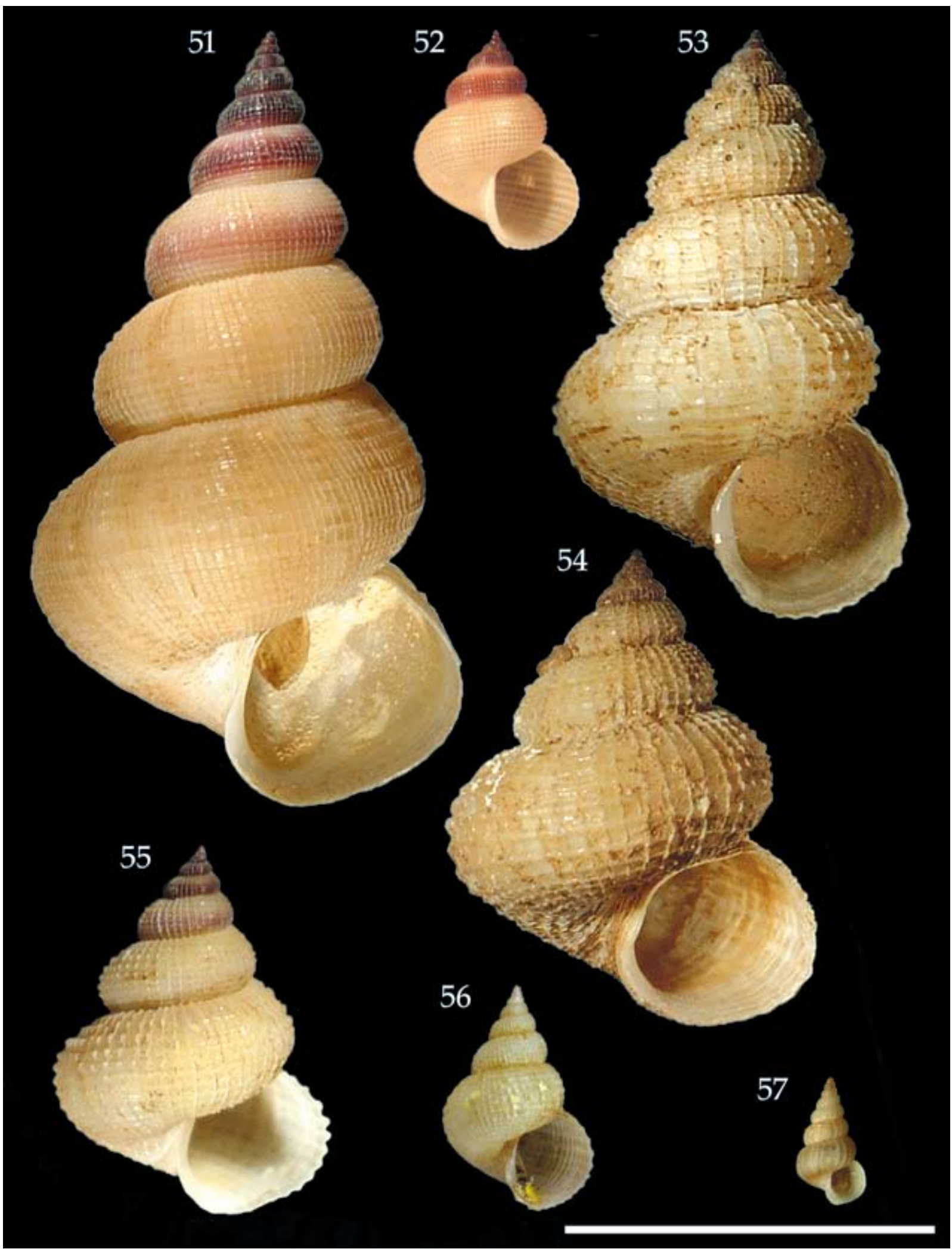


Epidendrium sordidum spec. nov.

Material (all hosted by Tubastrea or Dendrophyllia spp). INDONESIA.N Sulawesi: Selat Lembeh, between Tanjungnanas and Teluk Kungkungan $\left(01^{\circ} 28^{\prime} \mathrm{N} 125^{\circ} 15^{\prime} \mathrm{E}\right)$, holotype RMNH $100208 / 1 \mathrm{sh}$; N Lembeh Strait, W Lembeh Island (01 ${ }^{\circ} 30^{\prime} 01^{\prime \prime N}$ $\left.125^{\circ} 15^{\prime} 39^{\prime \prime} \mathrm{E}\right), 100209 / 2 \mathrm{sh}$; Off Manado, Bunaken (0135'55'N 124\%46'01'E), 100181/1sn+e, 100211/1sn; Off Manado, Siladen (013'37'N 12448'01'E), 100182/1sn. SW Sulawesi, Spermonde archipelago: SW Samalona Island $\left(05^{\circ} 07^{\prime} 42\right.$ "S 119²0'31'E), RMNH 95239/1sn; W Badi Island (0458'05”'S 119¹6'54'E), RMNH 100186/2sn, 100187/1sn, 100188/1sn+e. Sulawesi, Wakatobi National Park, Karang Kapota NW, outer reef, RMNH 100180/5sn+e, d. Bali, Tulamben beach, Liberty wreck (08'16'26"S 115'35'28'"E), RMNH 95230/1sn+e. Komodo, S of Tanjung Toro Langkoi, Manta Ally (08 $44^{\prime} 12$ 'S $119^{\circ} 24^{\prime} 42^{\prime \prime E}$ ), RMNH 100192/2sh. MALDIVES. Ari Atoll, Vilamendhoo Island: House reef, (033'ㅅ $\left.72^{\circ} 57^{\prime} \mathrm{E}\right)$, RMNH 100212/1sn, d, 100210/1sn, d. PHILIPPINES. Cebu Strait, W Bohol: Cabilao Island, La Estrella Resort, RMNH 100213/3sn, 2d; W Cabilao Island, S-side fish sanctuary (09 52 '37'N 1234'38'E), RMNH 100183/16sn, d; S Cabilao Island, Cabacungan Point (0951'30'N 123\%45'57'E), RMNH 100185/21sn, $7 \mathrm{sh}, 2 \mathrm{r}, \mathrm{o}, \mathrm{d}$. PALAU. W Ulong, W of barrier reef, Tsey's tunnel (07¹8'40”N 134¹3'30'E), RMNH 100189/3sn+e, 2sh, d; W Babelthuap, Toachel Mlengui, North side of West Passage (07³2'31'N 134²8'24'E), RMNH 100191/2sn, d; E Babelthuap, E of Arudowaishi Pt., Uchelbeluu reef, backreef $\left(07^{\circ} 18^{\prime} 40^{\prime \prime} \mathrm{N}\right.$ 134¹3’30’E), RMNH 100193/2sn.

Type locality. INDONESIA. N Sulawesi: Selat Lembeh, between Tanjungnanas and Teluk Kungkungan $\left(01^{\circ} 28^{\prime} \mathrm{N} 125^{\circ} 15^{\prime} \mathrm{E}\right)$.

Shell (figs 1-2, 53-55, 93, 119; table 1). The shell height/width indexes (table 1) vary considerably, from 1.1 to 1.8 , resulting in shells varying from broad-conical (figs 54-55) to relatively slenderconical (fig. 53). Shell (figs 1-2, 53-55) fragile, with convex whorls; reaching $16.0 \mathrm{~mm}$ in height. For dimensions and number of costal and spiral ribs on the $2^{\text {nd }}$ and the $5^{\text {th }}$ teleoconch whorls, see table 1 . The protoconch is entirely coloured with a dark, purplish red pigment, which continues on the teleoconch whorls, where it is most conspicuous below

Figs 51-57. Shells. Figs 51-52, Epidendrium aureum spec. nov.; 51, holotype, Palau; 52, paratype, Egypt. 53-55, E. sordidum spec. nov.; 53, holotype, Sulawesi, Indonesia; 54, paratype, relatively broad specimen, Palau; 55, paratype, exceptionally clean specimen, Sulawesi, Indonesia. 56, E. billeeanum, holotype, Gulf of California, USA. 57, E. dendrophylliae, Malaga, Spain. Scale bar $=1 \mathrm{~cm}$. Photos: A. Gittenberger (51-55, 57) and J. Goud (56). the periphery, gradually fading out and not visible anymore from about the $4^{\text {th }}$ teleoconch whorl onwards. The remaining parts of the teleoconch are white to yellowish. The holotype (fig. 53) measures $16.0 \times 9.0 \mathrm{~mm}$. The protoconch (fig. 93) has $3 \frac{1 / 4-31 / 2}{2}$ whorls $(\mathrm{n}=10)$; apart from its smooth apical part, it is sculptured with regularly spaced, very fine, incised, axial lines, 20-25 $(\mathrm{n}=2)$ per $0.2 \mathrm{~mm}$ on protoconch whorl $2 \frac{1}{4}-2^{3 / 4}$. The teleoconch (figs $1-2,53-55,119$ ) has up to 7 whorls, separated by a moderately deep suture; it is sculptured with mostly regularly placed, discontinuous, orthocline, lamellar, not or slightly curved, low costae, not or hardly touching the adjoining whorls. The number of costae on the $2^{\text {nd }}, 3^{\text {rd }}, 5^{\text {th }}$ and younger teleoconch whorls increases quickly, up to 80 costae on the $6^{\text {th }}$ whorl in a shell of $7.0 \mathrm{~mm}$ in height. The teleoconch is additionally sculptured with regularly placed, relatively thick, spiral threads. The number of prominent spiral threads on the $2^{\text {nd }}, 3^{\text {rd }}$, and $5^{\text {th }}$ teleoconch whorl slowly increases at first, usually remaining approximately constant from the $6^{\text {th }}$ whorl onwards; there are up to 10 spirals on a whorl. The low costal ribs increase abruptly two to three times in height when crossing a spiral thread, forming distinct protuberances on the shell's surface. Mucus threads, dirt and sand are caught in between these protuberances; small bivalves, vermetid gastropods, polychaetes and foraminifers, often settle on them (figs 1-2); small circular holes of unknown origin, are commonly found in between the costae (see teleoconch whorls 4-5 of the holotype, fig. 53). Therefore, when collecting the snails in the field, they are usually so dirty that the whorls cannot be distinguished. Cleaning takes some effort and normally results in shells that still look worn and dirty (figs 53-54), and only rarely "clean" (fig. 55). Aperture subcircular. There is a moderately wide umbilicus.

Operculum (fig. 134). Operculum paucispiral, with interconnected coils as in Surrepifungium patamakanthini spec. nov. (fig. 3). Except for growth lines, no micro-sculpture (fig. 134) is discernable on the outside of the opercula $(n=4)$.

Radula (figs 162, 182, 202; table 2). Three radulae could be studied, i.e. one from a specimen from the Philippines and two from Indonesian snails (table 2). The stem and the blade of each tooth are similar in width and merge gradually; the blade has 1-9 acute, 


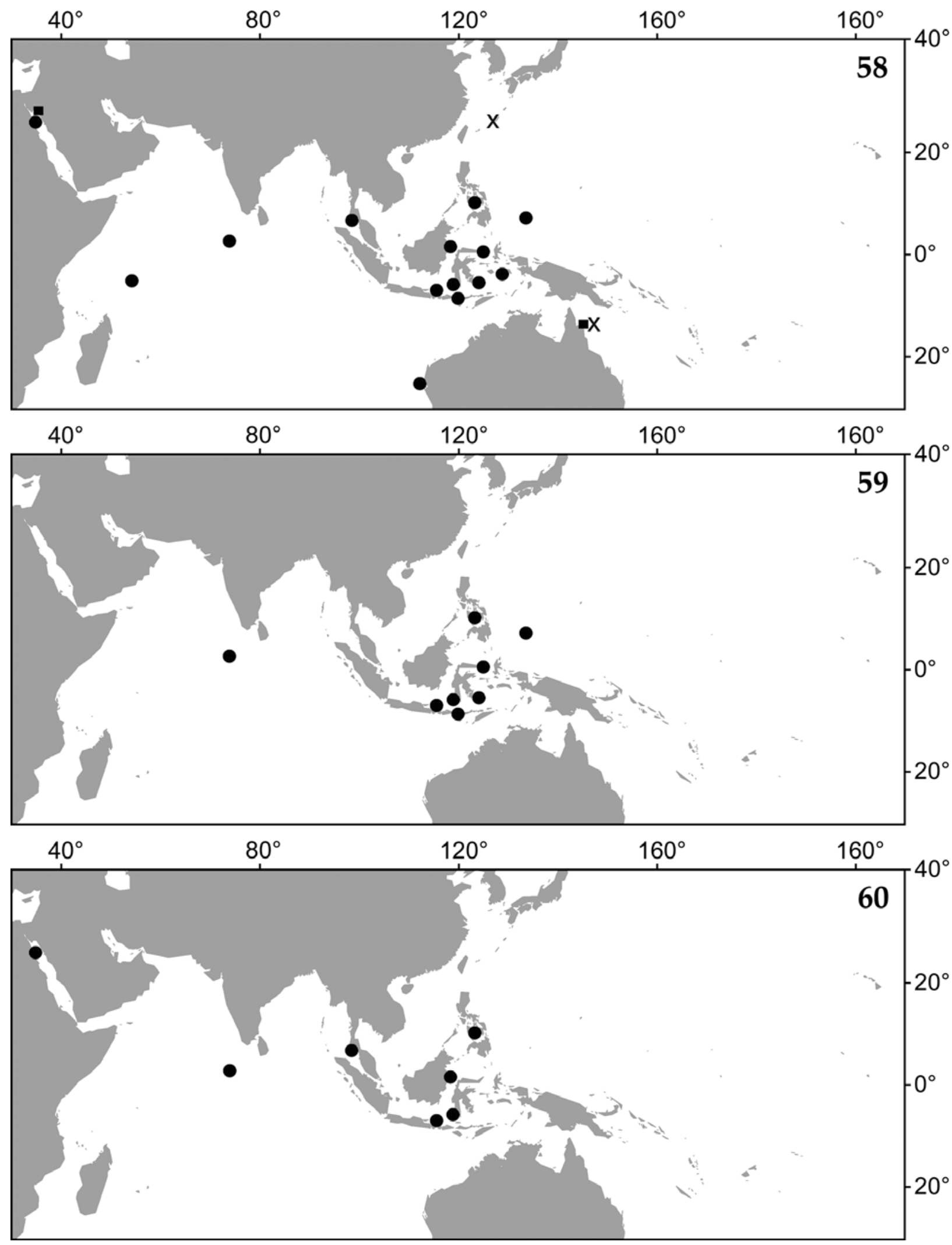


secondary cusps. The teeth (figs 160-161) are attached to the radular plate along the bases up to an inconspicuous, small, basal denticle (fig. 202). The number of secondary cusps gradually increases from 1 on the innermost tooth (fig. 182, left) to 9 on the teeth about halfway, after which the number gradually decreases to 2 on the ultimate tooth. The apical cusp is about two to three times larger than the secondary cusp underneath it. Secondary cusps gradually become smaller further down the blade of a tooth (fig. 202). Only the radula of the holotype (figs 162, $183,203)$ could be preparated good enough to accurately measure and count all teeth. It looks similar to the other two radulae that were studied. Starting from the innermost, smallest tooth, with a height of $0.041-0.044 \mathrm{~mm}(\mathrm{n}=2)$, the teeth gradually increase in size to somewhat more than twice that height, i.e. $0.108 \mathrm{~mm}(\mathrm{n}=1)$, up to the $46^{\text {th }}$ tooth, after which they gradually become smaller again until the ultimate, $0.074 \mathrm{~mm}(\mathrm{n}=1)$ high $59^{\text {th }}$ tooth (table 2).

Jaw (figs 20, 239-242; table 2). The denticulate edge consists of a row of slender, blunt denticles, which are densely pitted basally, on the inside (fig. 239). They have a maximum size of $0.0063-0.0080 \mathrm{~mm}$ (n $=2$ ). Seen from the outside (figs 240-242), 30-31 denticles $(\mathrm{n}=2)$ per $0.05 \mathrm{~mm}$ extend above a 0.016 $0.019 \mathrm{~mm}(\mathrm{n}=2)$ broad, granulated jaw-flap (figs 240-241), which lies loosely over part of the jaw-pattern (figs 240, 242). Sometimes this pattern is obsolete under the jaw-flap (fig. 241). When it is not (figs 240,242 ), it consists of two or three rows of somewhat sunken, scarcely pitted, pentagonal figures (fig. 240), followed further on by more or less unclear rows of somewhat sunken, scarcely pitted, pentagonal or oval to irregular figures that occasionally have holes (figs 20, 242). Away from the denticulate edge, the pattern gradually becomes obsolete (fig. 241). On the inner surface of the jaw (fig. 239), below the denticles, there are three or four rows of engraved, scarcely pitted, irregularly square-like figures, followed by an area that is somewhat granulated to smooth.

Figs 58-60. The Indo-Pacific region, from the Red Sea to the Hawaiian archipelago, illustrating epitoniid species ranges. Records of collected material (dots), observed, but not collected material (crosses) and based on photographs only (squares); 58, Epidendrium aureum spec. nov.; 59, Epidendrium sordidum spec. nov.; 60, Epifungium adgranulosa spec. nov.
Spawn (figs 274-275). Egg-capsules (fig. 274) ovoid, yellowish, somewhat transparent, with conspicuous protuberances, not embedded with sand, 1.57-2.00 $\mathrm{mm}($ mean $=1.79, \mathrm{n}=9)$ in diameter, e.g. measured horizontally, from left to right in figure 274, containing 240-530 eggs $($ mean $=382.0, \mathrm{n}=9)$ each. The mucus threads that connect the egg-capsules, are either straight (fig. 275) or twisted (as in Epifungium hartogi, fig. 284), and either smooth (as in Epidendrium aureum spec. nov., fig. 273) or sculptured with longitudinal lines (fig. 275).

Habitat. The snails and their egg-capsules were found at 3-35 m, associated with Tubastrea and Dendrophyllia corals. They usually live on, or in the vicinity of their dendrophylliid hosts, attached to the surface of the substrate with mucus threads. The host corals occur most commonly fixed to the underside of large boulders, in crevices, on the ceilings of caves or on the steep walls of drop-offs. The snails are often found together with those of Epidendrium aureum spec. nov. with the same coral host colony.

Distribution (fig. 59). The species is known from the Indo-West Pacific, from Maldives, Philippines and Indonesia to Palau.

Differentiation. See the differentiation of Epidendrium aureum spec. nov.

Etymology. This species is named after its appearance. Most shells, even of alive specimens, look worn and "dirty", i.e. "sordidum" in Latin.

Remarks. According to Dr. R. Bieler (pers. comm., 2005) the attached vermetid shell illustrated in figs $1-2$, might be of a very young Dendropoma spec. (Gastropoda, Vermetidae). See the remarks on Epidendrium aureum spec. nov.

\section{Epifungium gen. nov.}

Type species. Epitonium ulu Pilsbry, 1921

Other species. Epifungium adgranulosa spec. nov.; Epifungium adgravis spec. nov.; Epifungium adscabra spec. nov.; Epitonium hartogi A. Gittenberger, 2003; Epitonium hoeksemai A. Gittenberger and 


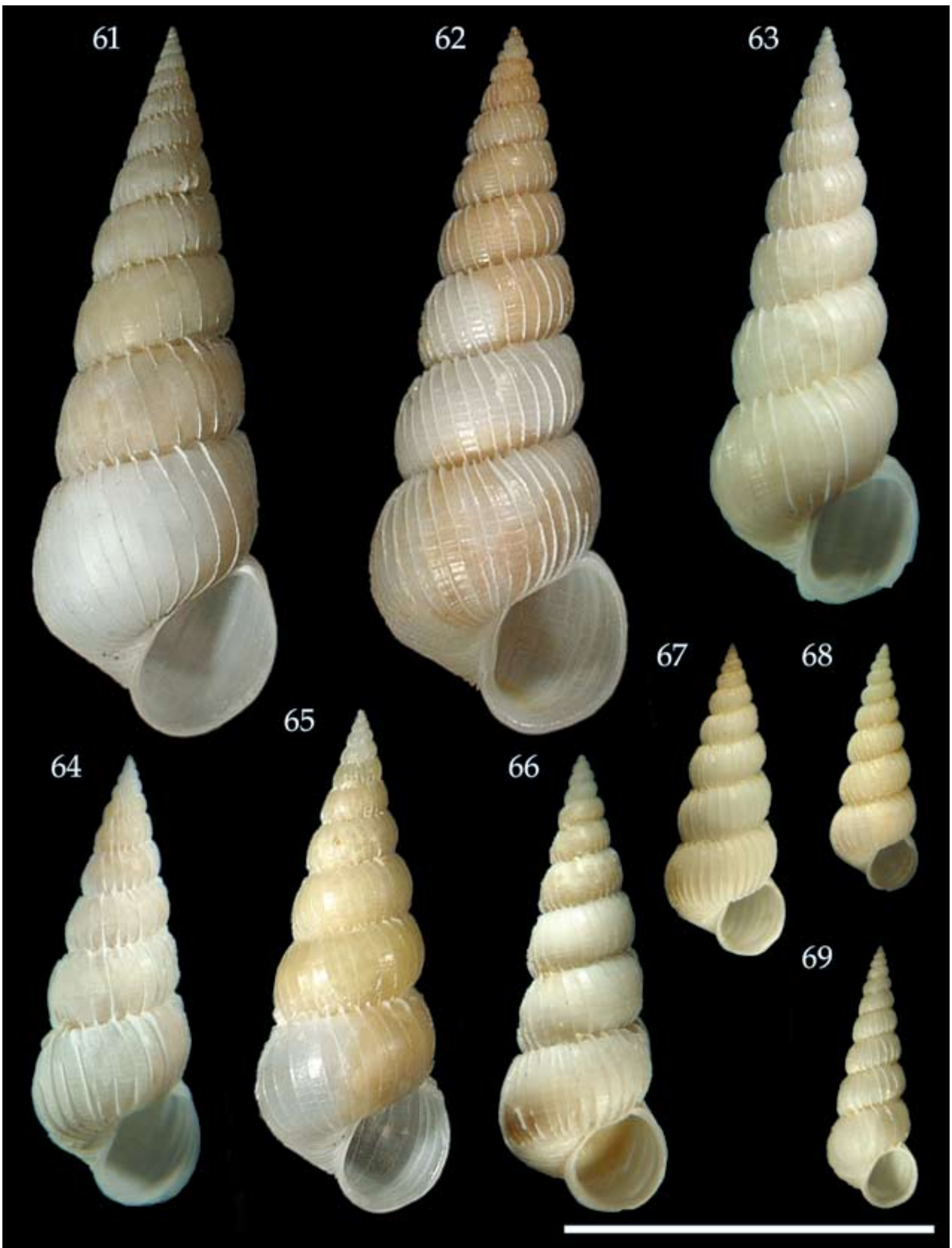


Goud, 2000; Epitonium lochi A. Gittenberger and Goud, 2000; Epifungium marki spec. nov.; Epifungium nielsi spec. nov.; Epifungium pseudolochi spec. nov.; Epifungium pseudotwilae spec. nov.; Epitonium twilae A. Gittenberger and Goud, 2000.

Shell (table 1). The fragile, whitish shells have a teleoconch sculpture of low costal ribs and spiral threads.

Operculum. Twenty to forty wavy threads per 0.1 $\mathrm{mm}$, running about perpendicular to the growth lines over the outside of the operculum (figs 140-151).

Soft parts. The animal is whitish, with small, dark eyespots.

Radula (table 2). All teeth have an acute apical cusp and one to six secondary cusps; no basal denticle is present (figs 15, 169-174, 189-194, 209-214).

Jaw (table 2). The denticulate jaw-edge consists of a single row of slender, blunt denticles (figs 31-32, 243-263). Underneath these denticles, there is a prominent, usually loose jaw-flap, partly covering the outside jaw-pattern (figs 243-245, 249-259).

Spawn. The egg-capsules are oval to round, with or without protuberances, transparent or covered with sand. They are connected by a straight or twisted mucus thread (figs 276-299). The uncleaved eggs are $0.077 \mathrm{~mm}(\mathrm{n}=10 /$ species $)$ in diameter. The development from eggs to veligers in the egg-capsules resembles that described for $E$. hartogi by A. Gittenberger (2003: 147, fig. 42). This development was studied for all Epifungium gen. nov. species, except E. adscabra spec. nov., E. marki spec. nov., E. pseudolochi spec. nov. and E. pseudotwilae spec. nov.

Habitat. The snails live under fungiid hosts (Fungiidae) on the coral itself or on the substratum under-

Figs 61-69. Shells. 61, Epifungium adgranulosa spec. nov., holotype, Thailand. 62, E. marki spec. nov., holotype, Egypt. Figs 63-64, E. adgravis spec. nov.; 63, holotype, Kalimantan, Indonesia; 64, paratype, Sulawesi, Indonesia. Fig. 65, E. nielsi spec. nov., holotype, Maldives. Figs 66-67, E. lochi, Sulawesi, Indonesia; 66, paratype; 67, holotype. Fig. 68, E. pseudolochi spec. nov., holotype, Egypt. Fig. 69, E. adscabra spec. nov., holotype, Sulawesi, Indonesia. Scale bar $=1 \mathrm{~cm}$. neath, with the exception of Epifungium hartogi, which is found on or in the vicinity of euphyllid hosts (Euphyllidae). When the snails are not on the coral surface, they are usually found on a hard substratum, like coral rubble and only rarely on sand.

Etymology. The name Epifungium is composed after "epi", Greek for "on", and "fungium", referring to the coral host family "Fungiidae". The gender is neuter, i.e. with the ending "ium".

Differentiation. A similar teleoconch sculpture of low costal ribs and spiral threads is present in Epidendrium gen. nov. (figs 1-2, 51-57, 92-93, 118-119) and some Epitonium species, e.g. E. striatissimum (Monterosato, 1878) (Bouchet and Warén, 1986: 522, fig. 1216).

A similar operculum sculpture of wavy threads, running about perpendicular to the growth lines, is present in Surrepifungium gen. nov. (figs 136-139). In that genus however, nine to twenty threads per $0.1 \mathrm{~mm}$ are present instead of twenty to forty in Epifungium. In Epidendrium aureum spec. nov. (figs 132-133), E. sordidum spec. nov. (fig. 134) and Epitonium pyramidalis (fig. 135), no operculum sculpture is present, except for the growth lines. The sculpture on the opercula of other epitoniids, if any, is unknown.

Most epitoniids have at least some teeth on their radula with a distinct basal denticle (e.g. figs 175-176, 178-180, 184-188, 195-196, 198-200, 205-207). Such a denticle is missing in Epifungium (figs 15, 189-194, 209-214), however.

The jaws, with a single row of denticles and a jawflap (figs 11, 243-263), closely resemble those in Epidendrium gen. nov. species (figs 236-242), but differ from the jaws in other epitoniid genera, i.e. Cirsotrema (figs 10, 215), Epitonium (figs 218-225), Gyroscala (figs 216-217) and Surrepifungium gen. nov. (figs 226-235), in denticle form, the presence of a jaw-flap, and/or the number of denticle rows.

Similar, round to oval egg-capsules are found in species of most epitoniid genera, with the exception of Surrepifungium gen. nov., in which only pentagonal, drop-shaped egg-capsules are present.

The habitat is partly shared with Surrepifungium gen. nov. species, which live in or on the sand underneath fungiid host corals. When they were found together $(\mathrm{n}=24)$, the snails of the Epifungium gen. nov. species were on the coral and Surrepifungium gen. nov. 


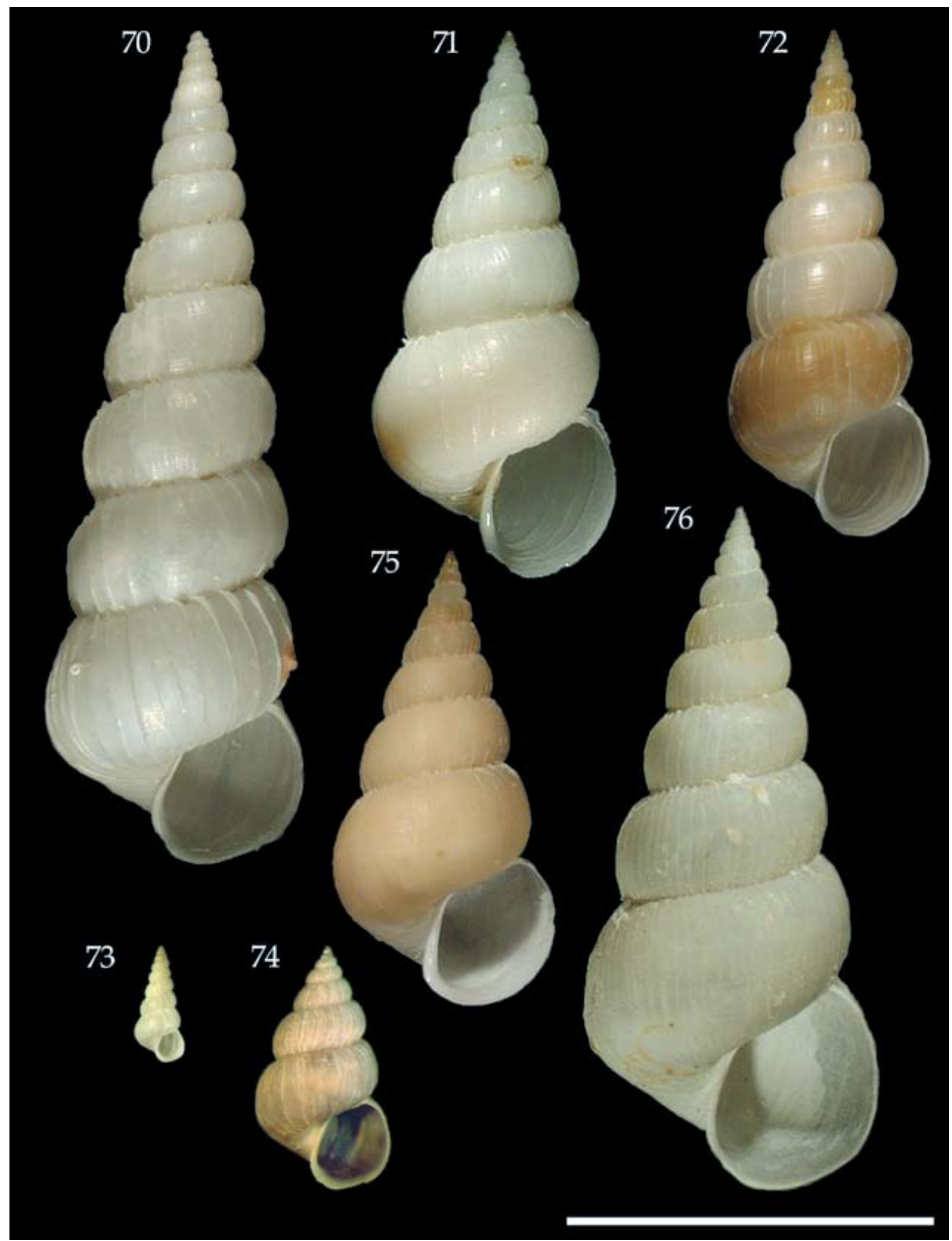


was found on or in the sand underneath. This is most likely due to a dislike of sand in Epifungium gen. nov. species, and not a matter of interspecific competition (A. Gittenberger and Hoeksema, in prep.). The habitat seems not to be shared with any other epitoniids.

\section{Epifungium adgranulosa spec. nov.}

Material (always hosted by Fungia (Wellsofungia) granulosa Kluzinger, 1879). THAILAND. Krabi, Phiphi Islands: Hin Bida, “Shark Point Phiphi”(07³8'01'N 9848'54”E), holotype RMNH 95961/1sh, with egg-capsules RMNH 100335; paratypes: type locality, RMNH 100336/1sh, found together with holotype; E Ko Phiphi Son, Poh Cape, Hin Phae (0743'30'N 9847'17'E), RMNH 96010/1sh, d. EGYPT. Off Marsa Shagra, about $300 \mathrm{~km}$ S of Hurghada, RMNH 95088/4sn+e, 95087/2sn+e, 95091/1sn, 95093/7sn+e, d; Off Marsa Nakari, about $350 \mathrm{~km} \mathrm{~S}$ of Hurghada, RMNH 95094/1sn, 95097/1sn+e. MALDIVES. Ari Atoll: Haamigili Beru reef, (0328'N 7250'E), RMNH 100128/1sn; Vilamendhoo Island, house reef, $\left(03^{\circ} 38^{\prime} \mathrm{N} 72^{\circ} 57^{\prime} \mathrm{E}\right), \mathrm{RMNH} 100127 / 1 \mathrm{sn}$, 100129/5sn+e, d, 100130/3sn+e. PHILIPPINES. Cebu Strait: Cabilao Island (off Bohol), La Estrella Resort, RMNH 62357/5sn, d; Gilutongan Island, RMNH 62353/4sn+e; Sulpa Island, RMNH 62355/7sn+e, 62356/1sn+e. INDONESIA. NE Kalimantan, Berau Islands, Berau delta, Lighthouse-2 reef $\left(02^{\circ} 09^{\prime} 34\right.$ 'N $118^{\circ} 10^{\prime} 11^{\prime \prime}$ ), RMNH 100126/1sh. SW Sulawesi, Spermonde archipelago: W Kudingareng Keke Island (0506'09"S $119^{\circ} 17^{\prime} 9$ 'E), RMNH 43163/1sn+e, 95030/1sn; ESE Kudingareng Keke Island (05'06'S $\left.119^{\circ} 17^{\prime} \mathrm{E}\right), \mathrm{RMNH} 43295 / 1 \mathrm{sn}$. Bali: N Nusa Penida Island, off Tukad Adegan (0840'32”S 115³1'18”E), RMNH 95027/1sh, o, r, d, 1sn; Padang Bai, E Tanjung Sari (08³1'11'S 115³0’37'E), RMNH 95004/1sn.

Type locality. THAILAND. Krabi, Phiphi Islands: Hin Bida, "Shark Point Phiphi"(07³8'01"N 98 48'54'E).

Shell (figs 61, 100, 120; table 1). Shell fragile, elongate-conical, with slightly convex whorls, creamy white; reaching $19.5 \mathrm{~mm}$ in height. For dimensions and number of costal and spiral ribs on the $2^{\text {nd }}$ and the $5^{\text {th }}$ teleoconch whorls, see table 1 . The holotype (fig. 61) measures $19.5 \times 7.0 \mathrm{~mm}$. The protoconch (fig. 100) has $3 \frac{1}{4}-3 \frac{1}{2}$ whorls $(n=10)$; apart from its smooth apical part, it is sculptured with regularly

Figs 70-76. Shells. Figs 70-73, Epifungium ulu; 70, largest specimen (28.2 mm), Bali, Indonesia; 71, broad specimen, Thailand; 72, slender specimen, Palau; 73, small specimen, Palau. Fig. 74, E. hartogi, Sulawesi, Indonesia. Figs 75-76, E. hoeksemai; 75, broad specimen, Sulawesi, Indonesia; 76, largest specimen (18.8 $\mathrm{mm})$, Palau. Scale bar $=1 \mathrm{~cm}$. spaced, very fine, incised, axial lines, $19(\mathrm{n}=1)$ per $0.2 \mathrm{~mm}$ on protoconch whorl $2 \frac{1}{4}-2^{3} / 4$. The teleoconch (fig. 120) has up to 10 whorls, separated by a shallow suture; it is sculptured with mostly regularly placed, usually discontinuous, orthocline, lamellar, low costae, touching the adjoining whorls, curving adaperturally at the preceding whorl. Just before reaching the preceding whorl the costae usually become about four times higher, forming a coronation. Although the number of costae on the $2^{\text {nd }}, 3^{\text {rd }}, 5^{\text {th }}$ and younger teleoconch whorls remains approximately the same (adjoining whorls differing $+/-2$ ) in about half of the specimens, this number may strongly increase or decrease on two or three whorls after which it remains constant again. There are up to 37 costae on a whorl, as was counted on the $9^{\text {th }}$ whorl in a shell of $8.5 \mathrm{~mm}$ in height. The teleoconch is additionally sculptured with very low, inconspicuous, spiral threads, randomly placed over each whorl. On the initial whorls the spiral threads are usually obsolete. Towards the younger whorls additional, low, spiral threads become apparent, usually (27 out of 31 ) becoming numerous from about the $7^{\text {th }}$ teleoconch whorl onwards. In some rare cases, 16 spiral threads are present on the $7^{\text {th }}$ teleoconch whorl (2 out of 33) or the spiral sculpture becomes obsolete on the younger whorls (2 out of 33). Aperture subcircular. Most specimens ( 30 out of 36 ) have a very narrow umbilicus, visible in oblique view only. Six specimens have a closed umbilicus. The relative umbilical width is not correlated with the shell-size.

Operculum (fig. 140). Operculum paucispiral, with interconnected coils as in Surrepifungium patamakanthini spec. nov. (fig. 3). At the outside of the operculum (fig. 140) there are 24 wavy, segmented threads per $0.1 \mathrm{~mm}(\mathrm{n}=1)$, running about perpendicular to the growth lines.

\section{Radula and Jaw. Unknown.}

Spawn (figs 276-277). Egg-capsules (fig. 276) ovoid, with conspicuous protuberances, somewhat transparent when not embedded with sand, $1.00-1.69 \mathrm{~mm}$ (mean $=1.24, \mathrm{n}=15$ ) in diameter, e.g. measured horizontally, from left to right in figure 276, containing 120-445 eggs (mean 183.2, $\mathrm{n}=15$ ) each. The mucus threads that connect the egg-capsules are strongly twisted and not sculptured (fig. 277). 

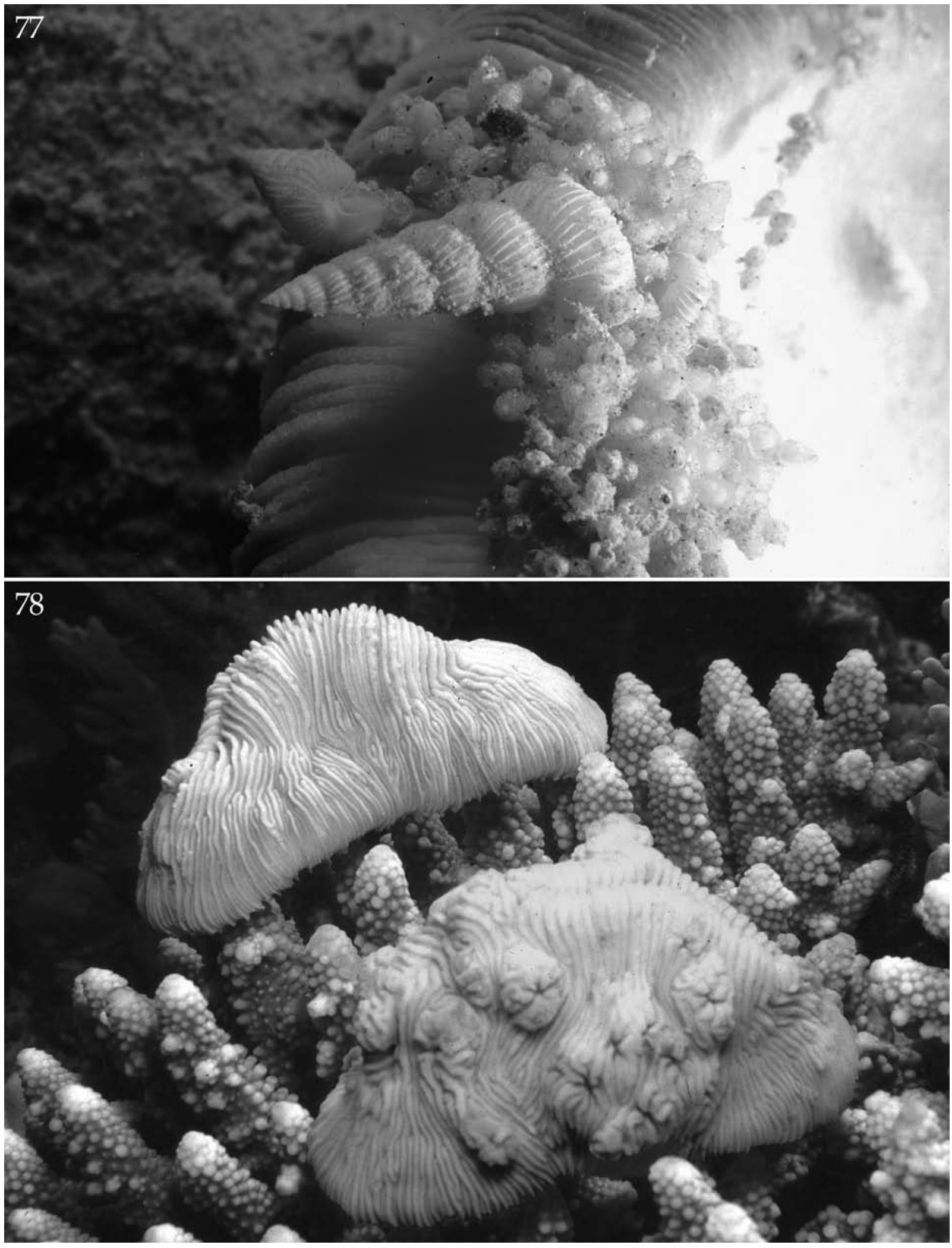
Habitat. The snails and their egg-capsules were found at 3-18 $\mathrm{m}$, associated with exclusively the mushroom coral species Fungia (Wellsofungia) granulosa Kluzinger, 1879. The snails usually live attached with their mucus threads to the underside of their hosts or to hard substrata underneath. Most host corals were found on coral slopes.

Distribution (fig. 60). The species is known from the Indo-West Pacific, from Egypt (Red Sea), Maldives and Thailand to Indonesia. Also off Palau, many specimens of the host coral species $F$. (W.) granulosa were thoroughly inspected for wentletraps but no Epifungium gen. nov. species were found there.

Differentiation. Conchologically this species resembles Epifungium adgravis spec. nov., E. marki spec. nov. and $E$. nielsi spec. nov. most. It differs from these species most clearly by its only slightly convex, instead of distinctly convex whorls and by the costal ribs touching the preceding whorls while curving adaperturally. Epifungium adgranulosa spec. nov. is the only epitoniid species that is known to be associated with Fungia (Wellsofungia) granulosa.

Etymology. This species is named after its restricted habitat. It was found exclusively on corals of Fungia (Wellsofungia) granulosa.

Remarks. See the remarks on Epifungium ulu.

\section{Epifungium adgravis spec. nov.}

Material (always hosted by Fungia (Pleuractis) gravis). INDONESIA. NE Kalimantan, Berau Islands: S Derawan Island, jetty Derawan Dive Resort (02 ${ }^{\circ} 17^{\prime} 03$ 'N 118 14'49'E), holotype RMNH 100135/1sh, with egg-capsules RMNH 100434; paratypes: type locality, RMNH 100132/3sn; SW Baliktaba reef, N of Panjang Island (02³4'43”N 11800'48”E), RMNH 100131/1sn; E Derawan Island, Coral Garden (02 $\left.17^{\prime} 32^{\prime \prime N} 118^{\circ} 15^{\prime} 43^{\prime \prime} \mathrm{E}\right)$, RMNH 100136/1sh, 1sn+e; Karang Pinaka reef, NW Samama

Figs 77-78. Epifungium marki spec. nov. and its host coral Fungia (Pleuractis) spec. A, off Marsa Shagra (Red Sea), Egypt. 77, E. marki, holotype (largest specimen, shell height $=19.2 \mathrm{~mm}$ ) with egg-capsules in situ; 78, F. (P.) spec. A, the two corals were collected on a sandy bottom and placed next to each other for better comparison; upper left specimen (coral length $=15 \mathrm{~cm}$ ), host of $E$. marki holotype; lower right specimen, morph with many secondary mouths, host of several E. marki paratypes.
Island (02¹1'22”N 118 17 '25”E), RMNH 100134/1sn; N Maratua Island, lagoon near entrance ( $\left.02^{\circ} 14^{\prime} 53^{\prime \prime} \mathrm{N} 118^{\circ} 37^{\prime} 36^{\prime} \mathrm{E}\right)$, RMNH 100133/2sn+e. N Sulawesi, Selat Lembeh, between Tanjungnanas and Teluk Kungkungan (01 $\left.28^{\prime} \mathrm{N} 125^{\circ} 15^{\prime} \mathrm{E}\right)$, RMNH 43347/1sh+e, r, d. SW Sulawesi, Spermonde archipelago: W Lae Lae Island (0508'09'S 119²3'13'E), RMNH 95053/1sn; NW Bona Baku reef (0507'56"S 119²1'39'E), RMNH 95051/1sn, 95050/1sn+e; SW Samalona Island (0507'42”S 119²0’31”E), RMNH 95077/4sn, 95078/2sn+e; W Bone Lola reef(0503'07'S 119'21'09'E), RMNH 95046/2sn+e; SW Barang

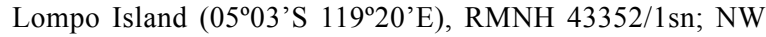
Kudingareng Keke Island (0506'08'S 119¹7'17'E), RMNH 43356/1sh+e, o, 43357/1sn+e; W Kudingareng Keke Island (0506'09”S 119¹7'09”E), RMNH 43276/1sn, 43308/1sn+e, 43165/1sn+e, 43368/3sn+e, 43369/1sn+e, 95031/1sn+e; SW Kudingareng Keke Island (0506'21'S 119¹7'03'E), RMNH

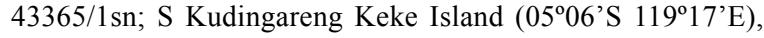
RMNH 43361/1sn, 43362/2sn+e; W Badi Island (04'58'05'S 119¹6'54'E), RMNH 43371/1sh, o, r, d, 95060/3sn+e; NW Bone Tambung Island (05'02'05'S $119^{\circ} 16^{\prime} 16^{\prime \prime}$ ), RMNH 43318/1sn+e, 95055/1sh; 1sn+e. Sulawesi, Wakatobi national park, Pasar Wajo, Buton (05'31'S 122 $51^{\circ}$ 'E), RMNH 100137/1sn. Moluccas, Ambon, Hitu, Ambon bay, outer bay, E Laha, up to and including Tawiri, RMNH 43343/1sn+e. Bali: SE-end Tulamben beach (08 16 '40”S $115^{\circ} 35^{\prime} 45^{\prime \prime}$ 'E), RMNH 95014/2sn+e; Tulamben area, “Temple bay" (08¹6'43"S 115³5'49”E), RMNH 95021/1sn; E Tanjung Sari (08'31'11'S 115³0'37'E), RMNH 95002/1sh+e, o, r, d, 95003/1sh+e; NE Serangan Island (08 44'03"S 115¹5'05'E), RMNH 94998/1sn; N Nusa Penida, off Tukad Adegan (0840'32'S 115³1'18'"E), RMNH 95026/1sn; N Nusa Penida, off Desa Buyuk (0840'25'S 115'32'37'E), RMNH 95028/1sn. W of Flores, NW Rinca, W Teluk Lehokkima (0838'54'S 119³9'58'E), RMNH 95150/1sn. NE Komodo, NE side of cape, S Gililawa Darat Island (08²8'50”S 119³3'13”E), RMNH 95151/1sn.

Type locality. INDONESIA. NE Kalimantan, Berau Islands: S Derawan Island, jetty Derawan Dive Resort (02¹7'03”'N 118 14'49”'E).

Shell (figs 63-64, 101, 121). Shell fragile, elongateconical, with convex whorls, creamy white; reaching $15.6 \mathrm{~mm}$ in height. For dimensions and number of costal and spiral ribs on the $2^{\text {nd }}$ and the $5^{\text {th }}$ teleoconch whorls, see table 1. The holotype (fig. 63) measures $15.6 \times 5.5 \mathrm{~mm}$. The protoconch (fig. 101) has $3 \frac{1 / 4-31 / 2}{2}$ whorls $(n=10)$; apart from its smooth apical part, it is sculptured with regularly spaced, very fine, incised, axial lines, $18(\mathrm{n}=1)$ per $0.2 \mathrm{~mm}$ on protoconch whorl $2 \frac{1 / 4}{4} 2^{3 / 4}$.

The teleoconch (fig. 121) has up to 10 whorls, separated by a deep suture; it is sculptured with mostly regularly placed, usually discontinuous, orthocline, lamellar, not to slightly curved, low costae, not 


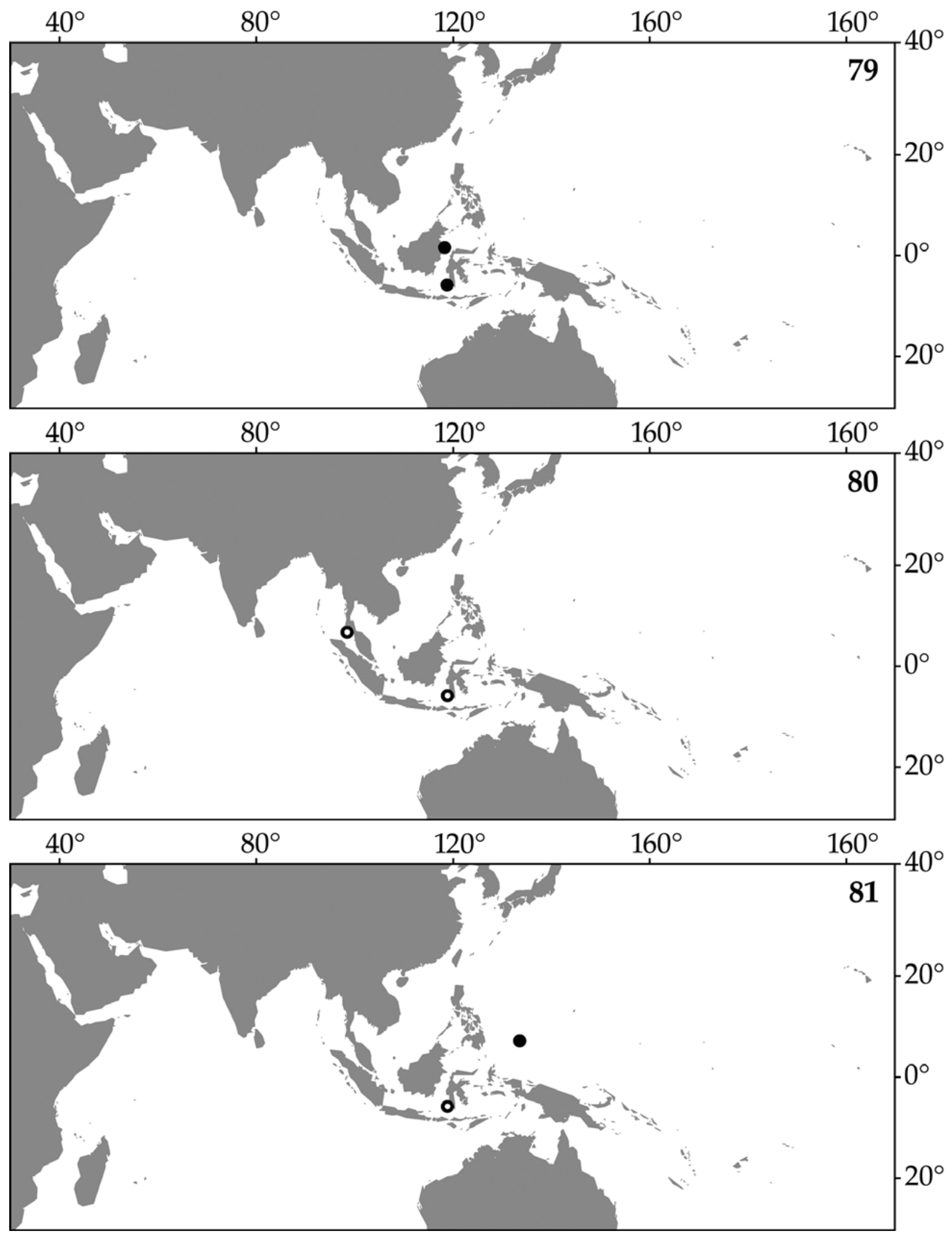


or hardly touching the adjoining whorls. Just before reaching the preceding whorl the costae become slightly coronate. The number of costae on the $2^{\text {nd }}$, $3^{\text {rd }}, 5^{\text {th }}$ and younger teleoconch whorls remains approximately the same (adjoining whorls differing in about two costae) in most cases; in a few specimens this number strongly increases or decreases on only two or three whorls. There are up to 31 costae on a whorl; on the $10^{\text {th }}$ whorl in a shell of $14.0 \mathrm{~mm}$ in height. Very fine, irregularly placed, incised, axial lines and/or split costae are present from the $7^{\text {th }}-9^{\text {th }}$ teleoconch whorl onwards. The teleoconch is additionally sculptured with irregularly placed, relatively thick, spiral threads. From the $6^{\text {th }}-9^{\text {th }}$ teleoconch whorl onwards, there are irregularly spaced, thin, spiral threads and incised spiral lines in between them and on the major spiral threads. There are usually less spiral threads above the periphery than below it; on the initial whorls they are usually obsolete above the periphery. The number of major spiral threads increases from the $2^{\text {nd }}$ to the $5^{\text {th }}$ whorl, after which it remains almost constant. From the $7^{\text {th }} 9^{\text {th }}$ whorl onwards, some of the incised spiral lines or low threads may gradually change into thick spiral threads. Aperture subcircular. In most specimens that are less than about $5 \mathrm{~mm}$ high (with 5-6 teleoconch whorls), the umbilicus is closed. Larger specimens have a very narrow umbilicus, visible in oblique view only.

Operculum (fig. 141). Operculum paucispiral, with interconnected coils as in Surrepifungium patamakanthini spec. nov. (fig. 3). At the outside of the operculum (fig. 141) there are 21-22 wavy, segmented threads per $0.1 \mathrm{~mm}(\mathrm{n}=2)$, running about perpendicular to the growth lines.

Radula (fig. 15; table 2). Two radulae from Indonesian snails could be studied. Both radulae curled and got damaged during SEM-preparation. Therefore it was hard to count the teeth in a row and as a consequence the numbers given below may not be accurate. Each tooth (fig. 15) consists of a moderately broad stem and a somewhat broader blade, which merge gradually; the blade has 1-6 acute, secondary cusps.

Figs 79-81. The Indo-Pacific region, from the Red Sea to the Hawaiian archipelago, illustrating Epifungium species ranges. New records (dots) and personally studied material (circles); 79, Epifungium adscabra spec. nov.; 80, E. hartogi; 81, E. hoeksemai.
The teeth (fig. 15) are attached to the radular plate along the bases, which takes about half of the length of a tooth. The number of secondary cusps (table 2) gradually increases from 1 on the innermost tooth to 6 on the $10^{\text {th }}$ tooth (fig. 15, indicated by "sc"), after which the number gradually decreases to 1 on the ultimate, i.e. $14^{\text {th }}$ tooth. The apical cusp and the secondary cusp directly underneath it are usually similar in size and somewhat curved towards each other; all other secondary cusps are slightly smaller, similar to each other in size, and usually not curved (fig. 15). Starting from the innermost, smallest tooth, with a height of $0.020 \mathrm{~mm}(\mathrm{n}=1)$, the teeth gradually increase in size to about two times that height, i.e. $0.042 \mathrm{~mm}(\mathrm{n}=1)$, up to the $10^{\text {th }}$ tooth, after which they gradually become somewhat smaller until the penultimate, $0.036 \mathrm{~mm}$ high $13^{\text {th }}$ tooth, which is followed by the much smaller $14^{\text {th }}$ ultimate tooth, with a height of $0.022 \mathrm{~mm}$ (table 2).

Jaw (fig. 253; table 2). Only the outer surface of one jaw could be studied. The denticulate edge consists of a row of slender, blunt denticles (fig. 253). They have a maximum size of $0.0033 \mathrm{~mm}$. Seen from the outside (fig. 253), 56 denticles per $0.05 \mathrm{~mm}$ extend above a $0.0100 \mathrm{~mm}$ broad, slightly granulated jawflap, which lies merged with the jaw over part of the jaw-pattern. This pattern, as far as visible under the jaw-flap, consists of two or three rows of somewhat sunken, densely pitted, pentagonal figures, under which the pattern is obsolete.

Spawn (figs 278-279). Egg-capsules (fig. 278) ovoid, without any protuberances, sometimes embedded with sand, 0.69-1.58 $\mathrm{mm}$ (mean $=1.22, \mathrm{n}=$ 15 ) in diameter, e.g. measured horizontally, from left to right in figure 278, containing 161-272 eggs (mean $=219.6, \mathrm{n}=13$ ) each. The mucus threads that connect the egg-capsules are straight and not sculptured (fig. 279).

Habitat. The snails and their egg-capsules were found at 6-30 m, associated with exclusively the mushroom coral species Fungia (Pleuractis) gravis Nemenzo, 1955. The snails usually live attached with their mucus threads to the underside of their hosts. Most host corals were found deeper than 20 meters, on a sandy, nearly flat bottom, situated along the lower border of a steeper coral slope. 


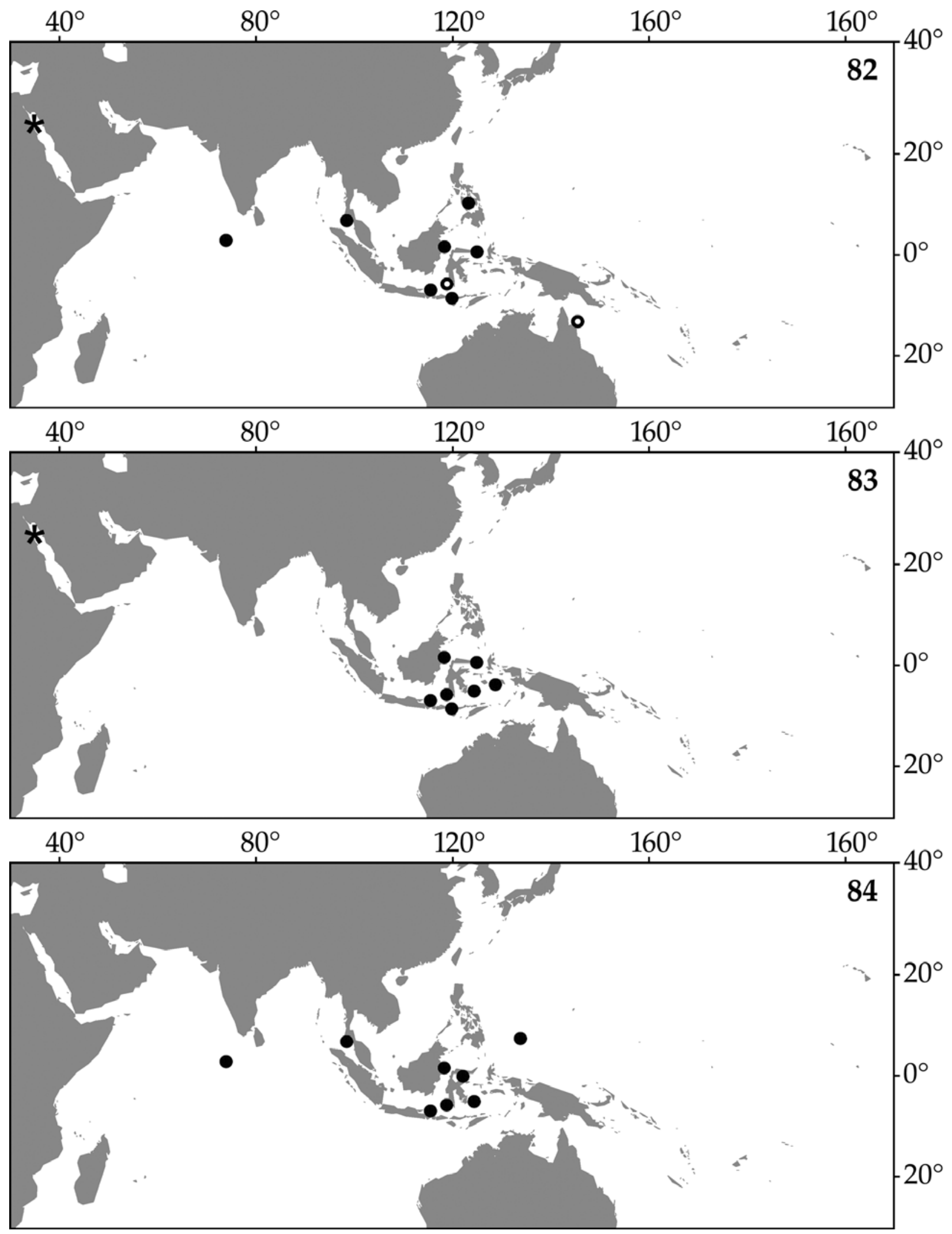


Distribution (fig. 83). The species is known from Indonesia only.

Differentiation. Epifungium adgravis spec. nov. is distributed throughout the Indo-Malayan area (fig. 83). It is the only epitoniid species that is known to be associated with Fungia (Pleuractis) gravis. Conchologically this species (figs 63-64, 101, 121) most closely resembles $E$. marki spec. nov. (figs 62,77 , 106, 126), which is endemic to the Red Sea (fig. 83). Epifungium adgravis spec. nov. differs from E. marki spec. nov. in having 23-31 costae (mean $=25.8, \mathrm{n}=$ 6) instead of 30-38 costae (mean $=33.3, \mathrm{n}=3$ ) on the $9^{\text {th }}-10^{\text {th }}$ teleoconch whorl, $18(\mathrm{n}=1)$ instead of $31(n=1)$ axial lines on protoconch whorl $2 \frac{1 / 4}{4}-2 \frac{3}{4}$ (figs 101, 106) and in having 21-22 wavy, segmented threads per $0.1 \mathrm{~mm}(\mathrm{n}=2)$ on the operculum instead of 34 per $0.1 \mathrm{~mm}(\mathrm{n}=1)$ (figs 141,146$)$. In $E$. marki spec. nov. the shells also have a somewhat deeper suture (figs 62-64). The shells of E. adgravis spec. nov. also resemble those of $E$. nielsi spec. nov. (figs $65,107,127$ ), differing especially by the more convex, somewhat broader whorls, which becomes apparent when the width of about the $3^{\text {rd }}$ teleoconch whorl is measured (table 1). Both major and minor spiral threads can be distinguished in most shells of E. adgravis spec. nov., but not in E. nielsi spec. nov. The spiral threads on the initial teleoconch whorls are usually obsolete above the periphery in $E$. adgravis spec. nov., where they are usually clearly discernible in E. nielsi spec. nov. The egg-capsules of $E$. adgravis spec. nov. and E. nielsi spec. nov. differ in being smooth (fig. 278) versus with many protuberances (fig. 290), connected to each other by a straight (fig. 279) versus a strongly twisted mucus thread (fig. 291), and by containing over 161 versus less than 137 eggs each.

Etymology. This species is named after its restricted habitat, being found exclusively on Fungia (Pleuractis) gravis Nemenzo, 1955.

Figs 82-84. The Indo-Pacific region, from the Red Sea to the Hawaiian archipelago, illustrating Epifungium species ranges. New records (dots and stars) and personally studied material (circles); 82, dots and circles $=$ Epifungium lochi, star in the Red Sea $=E$. pseudolochi spec. nov.; 83, dots =E. adgravis spec. nov., star in the Red Sea $=E$. marki spec. nov.; 84, E. nielsi spec. nov.
Remarks. Molecular analyses (A. Gittenberger et al., in prep.) indicate that Epifungium adgravis spec. nov. and E. adscabra spec. nov. (fig. 69) are sister species although they differ considerably conchologically. In shell characters E. adgravis spec. nov. is most similar to E. marki spec. nov., the sister species of E. pseudolochi spec. nov. These two species couples are sister groups again. See also the remarks on $E$. pseudolochi spec. nov.

\section{Epifungium adscabra spec. nov.}

Material (always hosted by Fungia (Verrillofungia) scabra). INDONESIA. SW Sulawesi, Spermonde archipelago: W Kudingareng Keke Island (05 06'09'S $119^{\circ} 17^{\prime}$ '09'E), holotype RMNH 95034/1sh, d with egg-capsules RMNH 100332; paratypes: type locality, RMNH 100333/1sn, 1sh, o, found together with holotype, RMNH 43178/1sh, 43225/1sh, 43225/1sh, 43174/1sh; E Kudingareng Keke Island (05 $06^{\circ}$ 'S $\left.119^{\circ} 17^{\prime} \mathrm{E}\right)$, RMNH $43279 / 1 \mathrm{sh}$, 43281/1sh, 43283/1sh, 43286/1sh, 43296/1sh, 43288/1sh, 43297/1sh, 43306/1sh; W Bona Baku reef (05\%07'56”'S 119²1'39'E), RMNH 43277/1sh, 43267/1sh; W Samalona Island (0507'31'S 119²0’31'E), RMNH 43229/1sh; E Samalona Island (05'07'28'S $119^{\circ} 20^{\prime} 38^{\prime \prime}$ ) , RMNH 43249/7sh, 43244/1sh, $43251 / 2$ sh. NE Kalimantan, Berau Islands, W Panjang Island (02'21'17'N 118'11'13'E), RMNH 100138/2sn, 1sh, o, d.

Type locality. INDONESIA. SW Sulawesi, Spermonde archipelago: W Kudingareng Keke Island (0506'09'S 119¹7’09'E).

Shell (figs 69, 102, 122; table 1). Shell fragile, elongate-conical, with convex whorls, creamy white; reaching $7.2 \mathrm{~mm}$ in height. For dimensions and number of costal and spiral ribs on the $2^{\text {nd }}$ and the $5^{\text {th }}$ teleoconch whorls, see table 1 . The holotype (fig. 69) measures $7.2 \times 3.8 \mathrm{~mm}$. The protoconch (fig. 102) has $3 \frac{1}{4}-3 \frac{1}{2}$ whorls $(n=10)$; apart from its smooth apical part, it is sculptured with regularly spaced, very fine, incised, axial lines, $23(\mathrm{n}=1)$ per $0.2 \mathrm{~mm}$ on protoconch whorl 21/4-23/4. The teleoconch (fig. 122) has up to $9 \frac{1}{4}$ whorls, separated by a moderately deep suture; it is sculptured with mostly regularly placed, usually continuous, orthocline, lamellar, low costae, touching the adjoining whorls, slightly curving adaperturally at the preceding whorl. Costae usually not coronate; some costae become slightly coronate, just before reaching the preceding whorl. The number of costae on the $2^{\text {nd }}, 3^{\text {rd }}, 5^{\text {th }}$ and younger teleoconch whorls remains approximately the same 


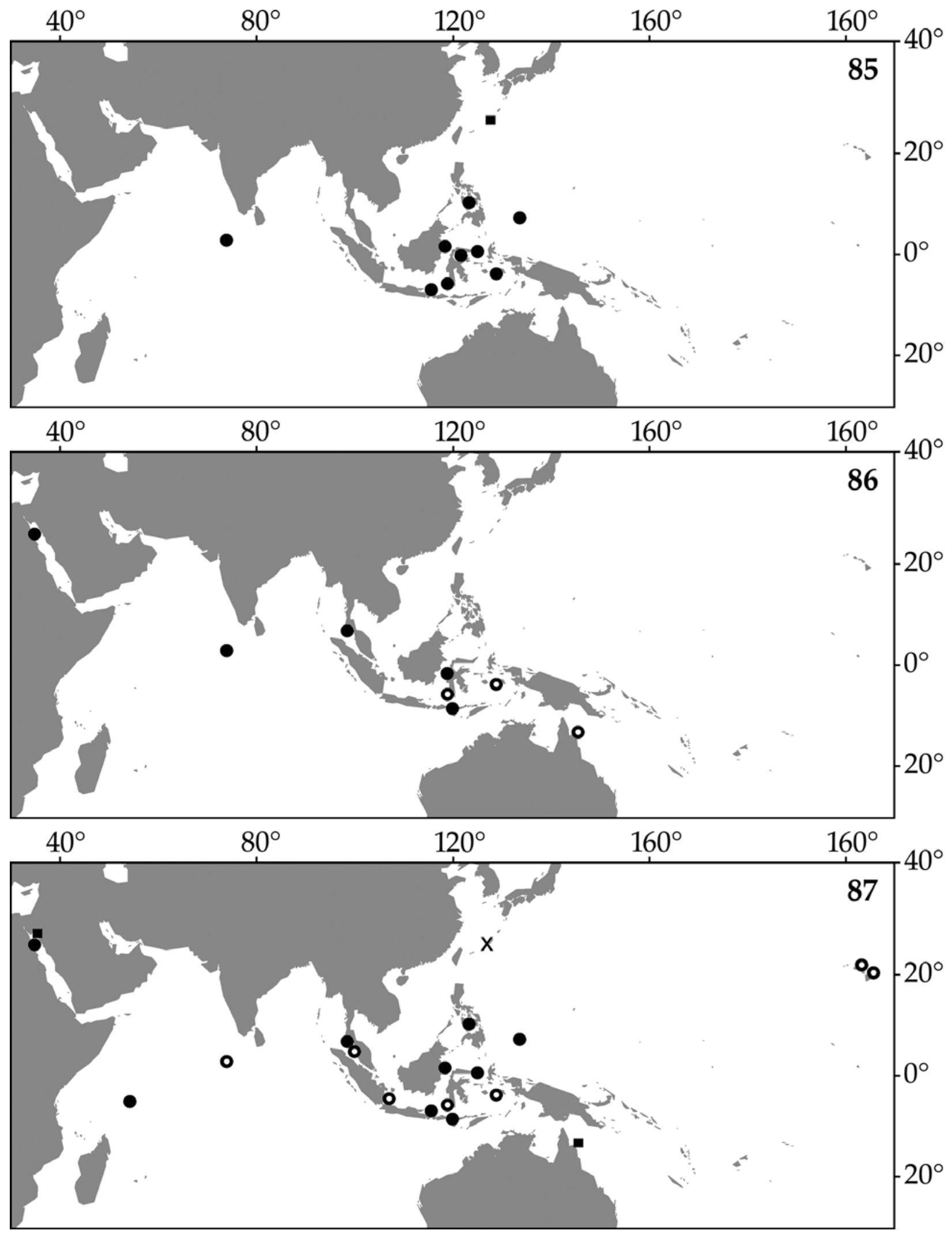


(adjoining whorls differing in about two costae). There are up to 23 costae on a whorl; on the $6^{\text {th }}$ whorl in a shell of $6.8 \mathrm{~mm}$ in height. The teleoconch is additionally sculptured with very low, inconspicuous, spiral threads. On some teleoconch whorls the spiral threads are obsolete; on the initial whorls they are usually obsolete above the periphery. Although the number of spiral threads approximately doubles between the $2^{\text {nd }}$ and the $5^{\text {th }}$ teleoconch whorl, it usually remains the same afterwards. In some specimens the number of spiral threads keeps on increasing strongly, resulting in numerous spirals from about the $7^{\text {th }}$ whorl onwards. Aperture subcircular. Half of the specimens (7 out of 14) have a very narrow umbilicus, visible in oblique view only. The other seven specimens have a closed umbilicus. The size of the umbilicus is not correlated with shell-size.

Operculum (fig. 142). Operculum paucispiral, with interconnected coils as in Surrepifungium patamakanthini spec. nov. (fig. 3). At the outside (fig. 142) there are 28 wavy, segmented threads per $0.1 \mathrm{~mm}(\mathrm{n}=1)$, running about perpendicular to the growth lines.

Radula and Jaw. Unknown.

Spawn (figs 280-281). Egg-capsules (fig. 280) ovoid, smooth, without any protuberances, embedded with sand, $0.75-0.91 \mathrm{~mm}($ mean $=0.82, \mathrm{n}=4)$ in diameter, e.g. measured horizontally, from left to right in figure 280 , containing 25-33 eggs $($ mean $=28.3, \mathrm{n}=4)$ each. The mucus threads that connect the egg-capsules are straight and not sculptured (fig. 281).

Habitat. The snails and their egg-capsules were found at 3-18 $\mathrm{m}$, associated with exclusively the mushroom coral species Fungia (Verrillofungia) scabra Döderlein, 1901. They usually live attached with their mucus threads to the underside of their hosts, close to the outer edge of the coral. Most host corals were found on coral slopes.

Figs 85-87. The Indo-Pacific region, from the Red Sea to the Hawaiian archipelago, illustrating Epifungium species ranges. New records based on collected material (dots) and observed, but not collected material (crosses). Published records, based on personally studied material (circles), photographs only (squares); 85, Epifungium pseudotwilae spec. nov.; 86, E. twilae; 87, E. ulu.
Distribution (fig. 79). The species has a relatively small range. It is only known from Indonesia.

Differentiation. The shells of this species resemble those of Epifungium adgravis spec. nov. and E. marki spec. nov., from which they can be distinguished by the much smaller width of the $5^{\text {th }}$ teleoconch whorl (figs 121-122, 126), the presence of on average 19-20 instead of $24-26$ costal ribs on the $2^{\text {nd }}, 3^{\text {rd }}$ and $5^{\text {th }}$ teleoconch whorls (table 1), and an average shell height/width index of 2.0 instead of 2.9 (table 1). Epifungium adscabra is the only epitoniid species that is known to be associated with Fungia (Verrillofungia) scabra.

Etymology. This species is named after its restricted habitat. It was found exclusively on corals of Fungia (Verrillofungia) scabra.

Remarks. See the remarks of Epifungium adgravis spec. nov. and E. ulu.

Epifungium hartogi (A. Gittenberger, 2003)

Epitonium hartogi A. Gittenberger, 2003: 139.

Material. INDONESIA (hosted by either Plerogyra simplex or $P$. diabolotus). SW Sulawesi, Spermonde archipelago: holotype (hosted by $P$. simplex) RMNH 94924 and RMNH 94925-94933 (22 paratypes, with 6 clutches of egg-capsules, $1 \mathrm{r}, 3 \mathrm{~d}$ ). THAILAND (hosted by P. diabolotus). Krabi, Phiphi Islands: 1 paratype with egg-capsules (RMNH 95989).

Type locality. INDONESIA. SW Sulawesi, Spermonde archipelago.

Shell (figs 74, 103, 123). Shell fragile, elongateconical, with convex whorls, purplish to creamy white; reaching $8.2 \mathrm{~mm}$ in height. For dimensions and number of costal and spiral ribs on the $2^{\text {nd }}$ and the $5^{\text {th }}$ teleoconch whorls, see table 1 . The protoconch (fig. 103) has 31/4-31/2 whorls $(n=10)$; apart from its smooth apical part, it is sculptured with regularly spaced, very fine, incised, axial lines, $15(\mathrm{n}=1)$ per $0.2 \mathrm{~mm}$ on protoconch whorl $2 \frac{1}{2}-3$. From the $5^{\text {th }}$ teleoconch whorl onwards, the shell is sculptured with irregularly spaced, irregularly placed, mostly split, usually not continuous, orthocline, low costae, without any particular notches or processes, barely 


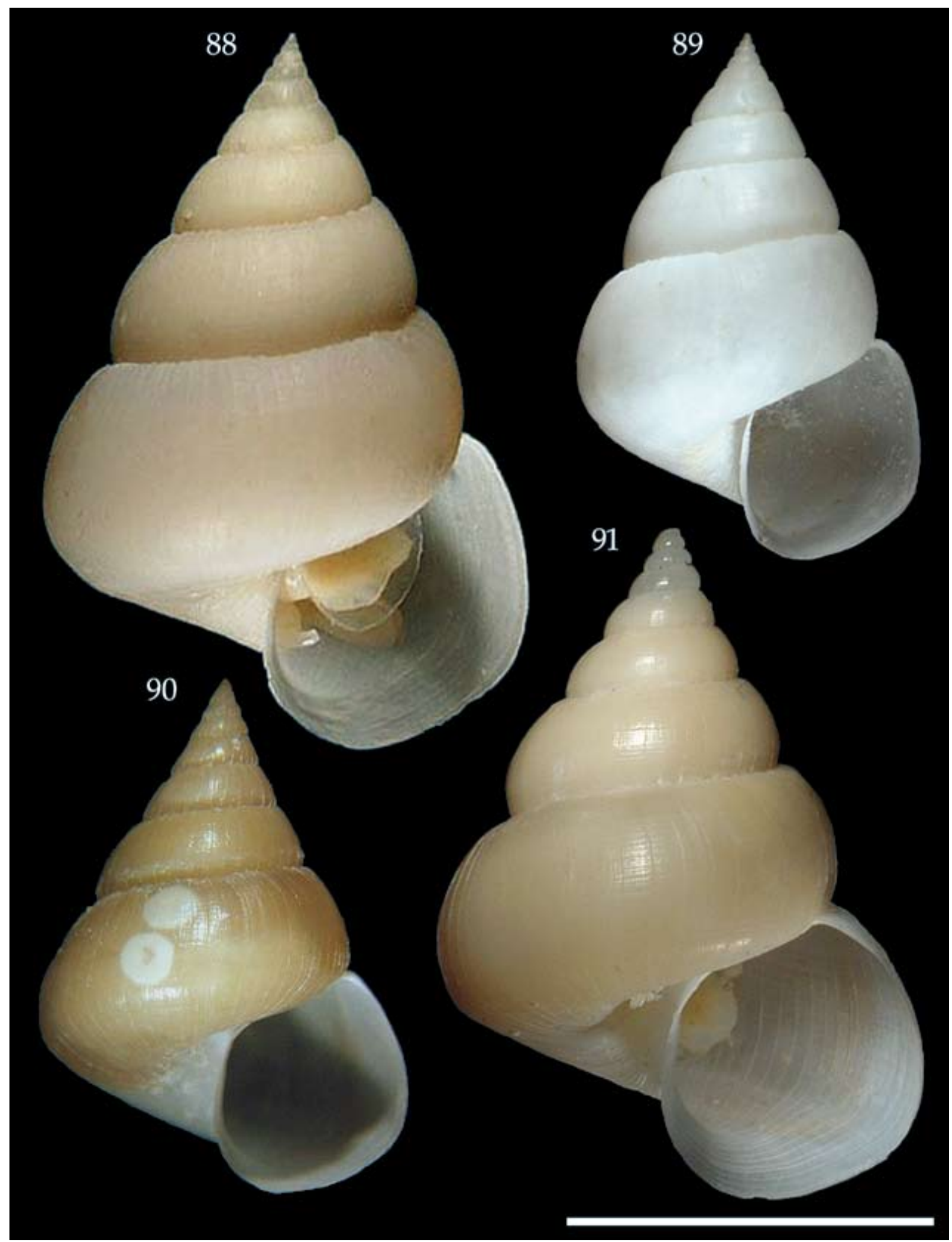


touching the adjoining whorls, and numerous low spiral ribs (fig. 123).

Operculum (fig. 143). Operculum paucispiral, with interconnected coils as in Surrepifungium patamakanthini spec. nov. (fig. 3). At the outside of the operculum (fig. 143) there are 23-24 wavy, segmented threads per $0.1 \mathrm{~mm}($ mean $=23.8, \mathrm{n}=4)$, running about perpendicular to the growth lines.

Radula (figs 169, 189, 209; table 2). Three radulae from Indonesian snails could be studied (A. Gittenberger, 2000: 143). The teeth could be counted accurately in one radula only (table 2 ). Each tooth (figs $169,189,209$ ) consists of a slender stem and broad blade, which merge gradually; the blade has 1-6 acute, secondary cusps. The teeth (fig. 169) are attached to the radular plate along the bases, which takes about half of the length of a tooth. The number of secondary cusps (table 2) gradually increases from 1 or 2 on the innermost tooth (fig. 189, left) to 6 on the penultimate, i.e. $24^{\text {th }}$ tooth (fig. 209 , right), after which the ultimate, i.e. $25^{\text {th }}$ tooth follows with 2 secondary cusps (fig. 169, right). The apical cusp and the secondary cusp directly underneath it are usually similar in size and somewhat curved upward, away from the stem; all other secondary cusps are slightly smaller, similar to each other in size, and usually not curved (figs 169, 209). Starting from the innermost, smallest tooth, with a height of $0.022 \mathrm{~mm}$, the teeth gradually increase in size to about two times that height, i.e. to $0.047 \mathrm{~mm}$ in the penultimate tooth, which is followed by the ultimate, usually malformed $25^{\text {th }}$ tooth, with a height of $0.040 \mathrm{~mm}$ (table 2).

Jaw (fig. 254; table 2). Only one jaw was studied (A. Gittenberger, 2000: 145). The denticulate edge consists of a row of slender, blunt denticles (fig. 254). They have a maximum size of $0.0035 \mathrm{~mm}$. Seen from the outside (fig. 254), 65 denticles per $0.05 \mathrm{~mm}$ extend above a $0.0179 \mathrm{~mm}$ broad, smooth to granulated jawflap, which lies merged with the jaw over part of the jaw-pattern. The pattern under the jaw-flap consists of three or four rows of somewhat sunken, pentagonal

Figs 88-91. Shells. 88-89, Epifungium twilae, SW Sulawesi, Indonesia; 88, paratype; 89, holotype. 90-91, E. pseudotwilae spec. nov.; 90, holotype, Palau; 91, paratype, Kalimantan, Indonesia. Scale bar $=1 \mathrm{~cm}$. figures, of which the lower two rows are densely pitted. Underneath this pattern the surface is smooth to granulate. The inner surface of the jaw is unknown.

Spawn (figs 282-283). Egg-capsules (fig. 282; A. Gittenberger, 2003: 140, fig. 8) ovoid, somewhat transparent, with conspicuous protuberances, not embedded with sand, 1.55-1.57 $\mathrm{mm}$ (mean $=1.56, \mathrm{n}$ $=4$ ) in diameter, e.g. measured horizontally, from left to right in figure 282, containing 230-415 eggs (mean $=328, \mathrm{n}=6)$ each. The mucus threads that connect the egg-capsules are strongly twisted and not sculptured (fig. 283).

Habitat. The snails and their egg-capsules were found at $9-18 \mathrm{~m}$, attached with mucus threads to the corals Plerogyra simplex Rehberg, 1892, and P. diabolotus Ditlev, 2003 (Scleractinia, Euphyllidae).

Distribution (fig. 80). The species is known from Thailand and Indonesia.

Differentiation. Epifungium hartogi is the only epitoniid species that is known to be associated with euphyllid corals. The shells differ from those of the similar species E. adgravis spec. nov., E. hoeksemai, E. marki spec. nov., E. nielsi spec. nov. and $E$. ulu, in their purplish colour and by the very irregularly spaced, irregularly placed, mostly split, low costae that are present from about the $5^{\text {th }}$ teleoconch whorl onwards. See A. Gittenberger (2003), for comparisons with the epitoniid species Epifungium hoeksemai, E. lochi, E. twilae, E. ulu, Epitonium albidum (Orbigny, 1842), "Epitonium billeeanum" (=Epidendrium aureum spec. nov.), E. millecostatum (Pease, 1860), E. pyramidalis, Surrepifungium costulatum, S. ingridae, and Nitidiscala tincta (Carpenter, 1865).

Remarks. See A. Gittenberger (2003), for a more detailed description. Here some additional data are given, with notes that may be relevant for the differentiation of this species.

Epifungium hoeksemai (A. Gittenberger and Goud, 2000)

Epitonium hoeksemai A. Gittenberger and Goud, 2000: 4-6, figs 9-10, 18, 20, 26, 43. 


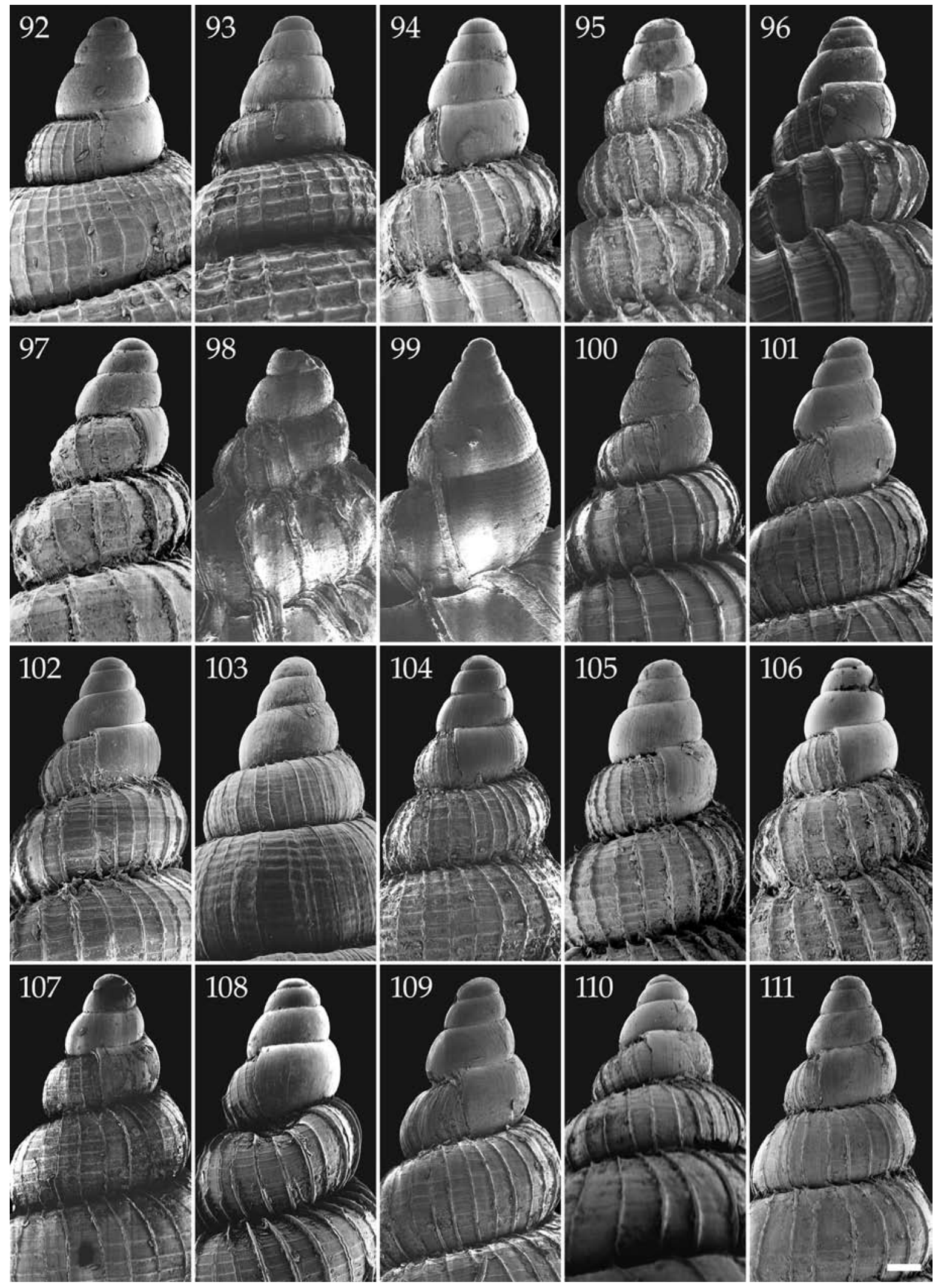


Material. INDONESIA (hosted by either Heliofungia actiniformis or Fungia (Fungia) fungites). SW Sulawesi, Spermonde archipelago: holotype (hosted by $F$. (F.) fungites): RMNH 59074 and 20 paratypes, viz. RMNH 59075-59087, with 4 clutches of eggcapsules. Additionally studied material: 40 specimens, 11 clutches of egg-capsules, 3 d. PALAU (all hosted by $F$. (F.) fungites). Off Koror: 12 specimens, 7 clutches of egg-capsules.

Type locality. INDONESIA. SW Sulawesi, Spermonde archipelago.

Shell (figs 75-76, 104, 124; table 1). Shell fragile, elongate-conical, with convex whorls, creamy white; reaching $19.0 \mathrm{~mm}$ in height. For dimensions and number of costal and spiral ribs on the $2^{\text {nd }}$ and the $5^{\text {th }}$ teleoconch whorls, see table 1 . The holotype measures $13.0 \times 5.6 \mathrm{~mm}$. The protoconch (fig. 104) has $3 \frac{1}{4}-3 \frac{1}{2}$ whorls $(n=10)$; apart from its smooth apical part, it is sculptured with regularly spaced, very fine, incised, axial lines, $22(\mathrm{n}=1)$ per $0.2 \mathrm{~mm}$ on protoconch whorl 21/4-23/4. The teleoconch (fig. 124) has up to 11 whorls, separated by a moderately deep suture; it is sculptured with mostly regularly placed, usually discontinuous, orthocline, lamellar, low costae, not or barely touching the adjoining whorls, slightly curving adaperturally at the preceding whorl. Just before reaching the preceding whorl the costae become slightly coronate. The number of costae on the $2^{\text {nd }}, 3^{\text {rd }}, 5^{\text {th }}$ teleoconch whorls increases quickly (table 1). Usually this number remains approximately the same (adjoining whorls differing in about two costae) from the $6^{\text {th }}$ whorl onwards (14 of 18 specimens). However, in some shells (4 of 18) it keeps on increasing, and then the number of costae per whorl approximately doubles between the $5^{\text {th }}$ and the $8^{\text {th }}$ teleoconch whorl, reaching up to 79 on the $10^{\text {th }}$ whorl in a shell of $18.8 \mathrm{~mm}$ in height. The teleoconch is additionally sculptured with very low, distinct, evenly distributed spiral threads. The number of spiral threads strongly increases towards the

Figs 92-111. Protoconchs. 92, Epidendrium aureum; 93, E. sordidum; 94, Surrepifungium costulatum; 95, S. ingridae; 96, S. patamakanthini; 97, S. oliverioi; 98, Epitonium crassicostatum; 99, E. graviarmatum; 100, Epifungium adgranulosa; 101, E. adgravis; 102, E. adscabra; 103, E. hartogi; 104, E. hoeksemai; 105, E. lochi; 106, E. marki; 107, E. nielsi; 108, E. pseudolochi; 109, E. pseudotwilae; 110, E. twilae; 111, E. ulu. 92, 94, 98, 100-104, 109, Indonesia; 93, 95-97, Palau; 99, Maldives; 105, 107, 110, 111, Thailand; 106, 108, Egypt. Scale bar $=0.1 \mathrm{~mm}$. SEM Photos. younger teleoconch whorls, becoming numerous from about the $6^{\text {th }}$ whorl onwards. Aperture subcircular. The shells have a narrow umbilicus, which is usually visible in oblique view only.

Operculum (fig. 144). Operculum paucispiral, with interconnected coils as in Surrepifungium patamakanthini spec. nov. (fig. 3). At the outside of the operculum (fig. 144) there are 30 wavy, segmented threads per $0.1 \mathrm{~mm}(\mathrm{n}=1)$, running about perpendicular to the growth lines.

Radula (figs 170, 190, 210; table 2). Two radulae from specimens from Palau could be studied (table 2). Each tooth has an irregularly triangular shape, starting very narrow and gradually becoming very broad towards the apical part (fig. 170). The stem and the blade merge gradually; the blade has 1-3 acute, secondary cusps. The teeth are attached to the radular plate along the bases, which takes about $3 / 4$ of the length of a tooth (figs 170, 190, 210). The innermost tooth has one secondary cusp while all other teeth usually have two; the $11^{\text {th }}$ tooth of one of the radulae has 3 secondary cusps (table 2). The straight, acute, secondary cusps are somewhat smaller than the acute, apical cusp, which is slightly curved upwards, away from the stem (figs 170, 190, 210). Starting from the innermost, smallest tooth, with a height of $0.018 \mathrm{~mm}$ $(n=2)$, the teeth gradually increase in size to about $1 \frac{1}{2}$ times that height, i.e. $0.027-0.028 \mathrm{~mm}(\mathrm{n}=2)$, up to the penultimate, i.e. $17^{\text {th }}-18^{\text {th }}$ tooth $(n=2)$, after which the ultimate, somewhat smaller, $18^{\text {th }}-19^{\text {th }}$ tooth, with a height of 0.022-0.025 $\mathrm{mm}(\mathrm{n}=2)$ follows (table 2).

Jaw (figs 11, 255-256, 261; table 2). The denticulate edge consists of a row of slender, blunt denticles, which are basally pitted on the inside (fig. 261). They have a maximum size of 0.0030-0.032 mm (n $=2$ ). Seen from the outside (figs 255-256), 58-64 denticles per $0.05 \mathrm{~mm}(\mathrm{n}=2)$ extend above a 0.0074-0.0120 mm $(\mathrm{n}=2)$ broad, smooth to granulated jaw-flap, which lies loosely over part of the jaw-pattern. The pattern under the jaw-flap consists of rows of pitted, sunken, pentagonal figures, gradually becoming obsolete away from the denticulate edge. On the inner surface of the jaw (fig. 261), just below the denticles, there is a row of engraved, scarcely pitted, irregularly square-like 


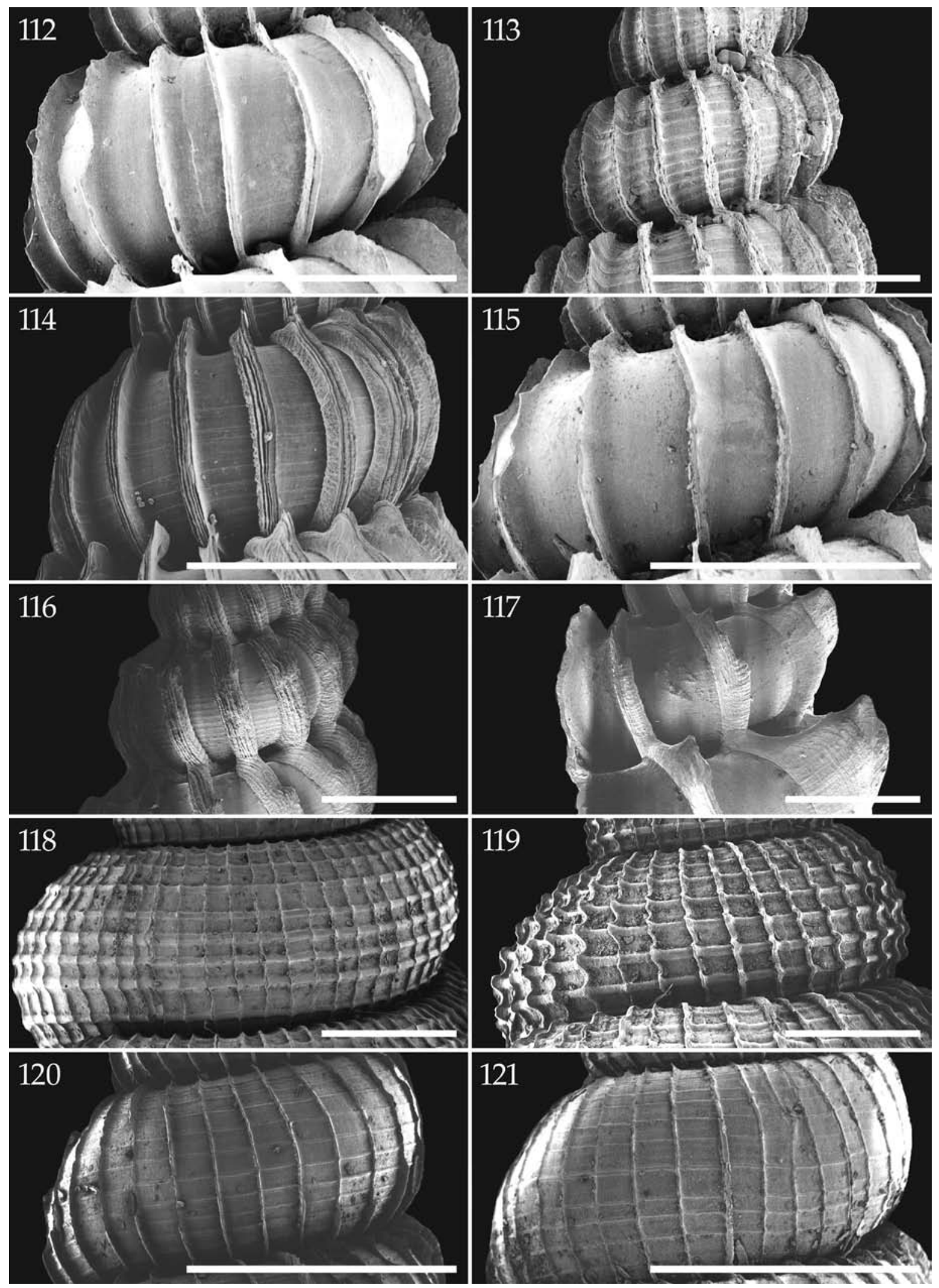


figures, followed by an area that is somewhat granulated to smooth.

Spawn (figs 284-285). Egg-capsules (fig. 284) ovoid, with distinct protuberances, sometimes embedded with sand, $1.11-1.85 \mathrm{~mm}$ (mean $=1.45, \mathrm{n}=6)$ in diameter, e.g. measured horizontally, from left to right in figure 284, containing 136-350 eggs (mean = $215.8, \mathrm{n}=6$ ) each. The mucus threads that connect the egg-capsules are strongly twisted and not sculptured (fig. 285).

Habitat. The snails and their egg-capsules were found at 1-20 m depth, associated with Heliofungia actiniformis (Quoy and Gaimard, 1833) and Fungia (Fungia) fungites (Linnaeus, 1758). They usually live attached with their mucus threads to the underside of these mushroom corals or to the hard substrata underneath. Sometimes the snails occur buried in the sand underneath the host. Most host corals were found on coral slopes.

Distribution (fig. 81). The species is known from Indonesia and Palau.

Differentiation. Conchologically this species resembles Epifungium adgravis spec. nov., E. marki spec. nov., E. nielsi spec. nov. and E. ulu. It differs most clearly from these species by the sculpture of spiral lines, which are distinct instead of sometimes obsolete on the initial teleoconch whorls, evenly distributed instead of more prominent underneath the periphery of a whorl and increasingly more numerous in between the $2^{\text {nd }}$ and the $5^{\text {th }}$ teleoconch whorl (table 1). On average the number of spiral threads on the $5^{\text {th }}$ teleoconch whorl is much higher and the shell height/width index is lower than in the most similar species (table 1).

Remarks. For a more detailed description of the shell and the proboscis, see A. Gittenberger et al. (2000).

Figs 112-121. T5 teleoconch whorls (see Fig. 1). 112, Surrepifungium costulatum; 113 , S. ingridae; 114, S. patamakanthini; $115, S$. oliverioi; 116, Epitonium crassicostatum; 117 E. graviarmatum; 118, Epidendrium aureum; 119, E. sordidum; 120, Epifungium adgranulosa; 121, E. adgravis. 112, 116, 118, 120-121, Indonesia; 113-115, 119, Palau; 117, Maldives. Scale bars $=1 \mathrm{~mm}$. SEM Photos.
Here some additional data are given, with notes that may be relevant for the differentiation of this species. See also the remarks on Epifungium ulu.

Epifungium lochi (A. Gittenberger and Goud, 2000)

Epitonium lochi A. Gittenberger and Goud, 2000: 9-10, figs 13-16, 37, 45.

?Epitonium species 4: Loch, 1982: 4-5, 1 fig. (see differentiation below).

Material. INDONESIA. SW Sulawesi, Spermonde archipelago (hosted by Fungia (Cycloseris) costulata, F. (C.) sinensis, F. (C.) somervillei, $F$. (C.) tenuis, $F$. (C.) vaughani), holotype (hosted by F. (C.) costulata): RMNH 59094 and 10 paratypes with 2 clutches of egg-capsules: RMNH 59095-59103. Additionally studied material: 19 specimens, 4 clutches of egg-capsules, $1 \mathrm{~d}$. N Sulawesi (hosted by Fungia $(C$.) costulata), 1 specimen. NE Kalimantan, Berau Islands (hosted by $F$. (C.) fragilis), 1 specimen, 1 clutch of egg-capsules. Bali (hosted by Fungia $(C$.) costulata, F. (C.) distorta, F. (C.) fragilis, F. (C.) somervillei, F. (C.) tenuis), 15 specimens, 3 clutches of egg-capsules, $1 \mathrm{~d}$. NE Komodo (hosted by $F$. (C.) fragilis, $F$. (C.) vaughani), 2 specimens, $1 \mathrm{~d}$. MALDIVES. Ari Atoll, off Vilamendhoo Island (hosted by $F$. (C.) tenuis), 1 specimen. THAILAND. Krabi, Phiphi Islands (hosted by $F$. (C.) fragilis and $F$. (C.) vaughani), 11 specimens, 4 clutches of egg-capsules, $2 \mathrm{~d}$. PHILLIPPINES. Cebu (hosted by $F$. (C.) costulata), 7 specimens, 1 clutch of egg-capsules. AUSTRALIA. Queensland, Lizard Island (hosted by $F$. (C.) spp.), from the Australian Museum, Sydney (AMS 329687-329688), 4 specimens, 1 clutch of egg-capsules.

Type locality. INDONESIA. SW Sulawesi, Spermonde archipelago.

Shell (figs 66-67, 105, 125; table 1). Shell fragile, elongate-conical, with convex whorls, creamy white; reaching $13.1 \mathrm{~mm}$ in height. For dimensions and number of costal and spiral ribs on the $2^{\text {nd }}$ and the $5^{\text {th }}$ teleoconch whorls, see table 1 . The holotype (fig. 67) measures $8.5 \times 3.7 \mathrm{~mm}$. The protoconch (fig. 105) has $3 \frac{1}{4}-3 \frac{1}{2}$ whorls $(n=10)$; apart from its smooth apical part, it is sculptured with regularly spaced, very fine, incised, axial lines, $20(\mathrm{n}=1)$ per $0.2 \mathrm{~mm}$ on protoconch whorl 21/4-23/4. The teleoconch (fig. 125 ) has up to $9 \frac{1}{2}$ whorls, separated by a very deep suture; it is sculptured with mostly regularly placed, usually discontinuous, orthocline, lamellar, not or slightly curved, low costae, not or hardly touching the adjoining whorls. Just before reaching the preceding whorl the costae become slightly coronate. In 3 out of 10 specimens the number of costae increases 


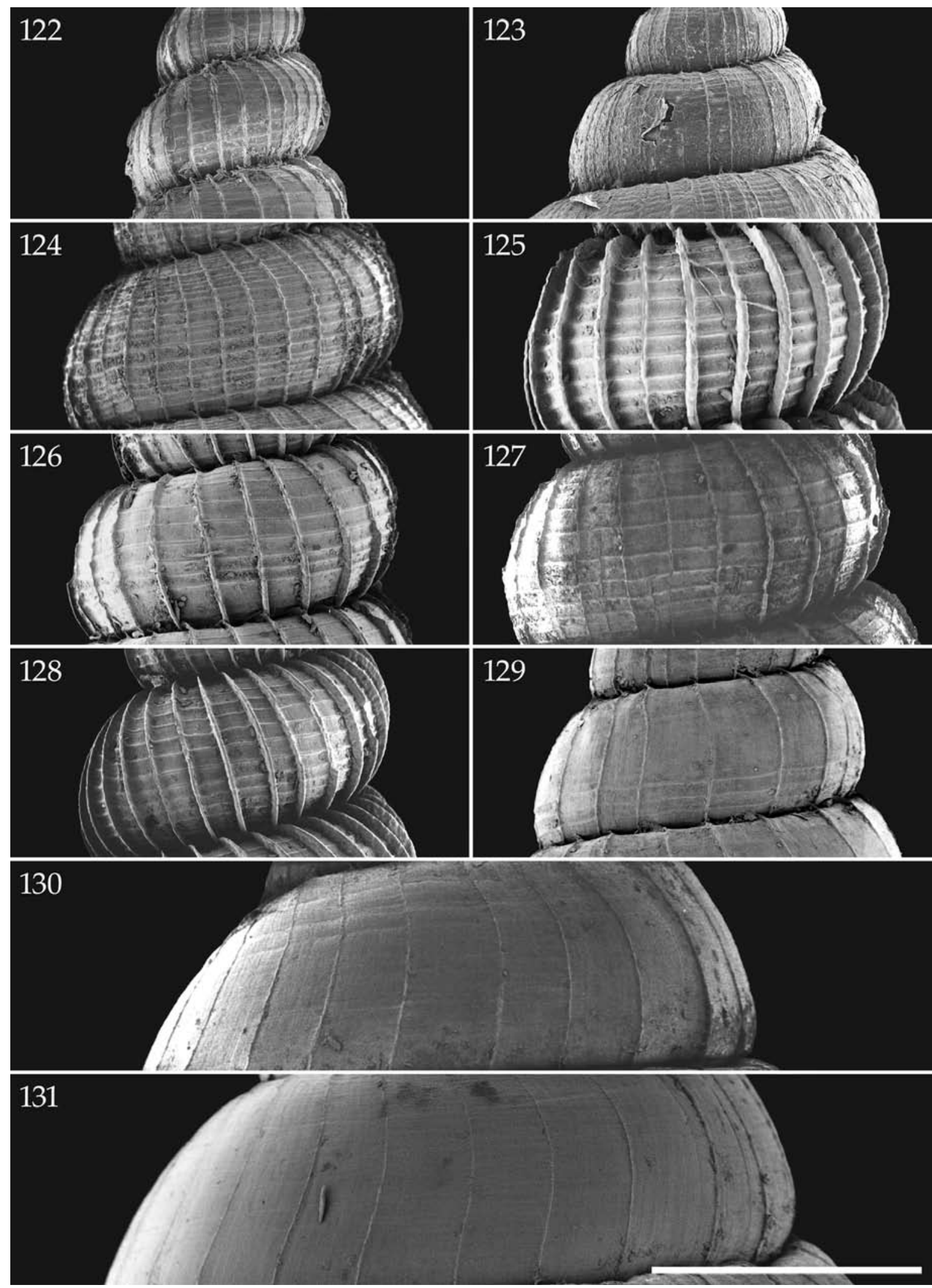


from the $3^{\text {rd }}$ teleoconch whorl onwards, whereas this number decreases in the remaining 7 shells, usually on the $6^{\text {th }}$ and $7^{\text {th }}$ whorl, after which it remains approximately the same. There are up to 26 costae on a whorl; on the $8^{\text {th }}$ whorl in a shell of $8.9 \mathrm{~mm}$ in height. The teleoconch is additionally sculptured with very low, distinct, evenly distributed spiral threads. The number of spiral threads gradually increases towards the younger teleoconch whorls, but only rarely becomes numerous. Aperture subcircular. The umbilicus is closed.

Operculum (fig. 145). Operculum paucispiral, with interconnected coils as in Surrepifungium patamakanthini spec. nov. (fig. 3). At the outside of the operculum (fig. 145) there are 24-29 wavy, segmented threads per $0.1 \mathrm{~mm}(\mathrm{n}=2)$, running about perpendicular to the growth lines.

Radula (figs 168, 171, 191, 211; table 2). Only one radula from an Indonesia snail could be studied (figs $168,171)$. The stem and the blade of each tooth are very slender, similar in width and merge gradually; the blade has 2-5 acute, secondary cusps. The teeth (figs 171, 191, 211) are attached to the radular plate along the bases, which takes about half of the length of a tooth. The number of secondary cusps (table 2) gradually increases from 2 on the innermost tooth (fig. 191, left) to 4 on the $5^{\text {th }}-10^{\text {th }}$ teeth, after which the penultimate and the ultimate, i.e. $12^{\text {th }}$ tooth, follow with 3 and 2 secondary cusps, respectively (fig. 211, right). The apical cusp and the secondary cusp directly underneath it are usually similar in size and somewhat curved towards each other; all other secondary cusps are slightly smaller, similar to each other in size, and curved upwards to the preceding secondary cusp (fig. 212). Starting from the innermost, smallest tooth, with a height of $0.018 \mathrm{~mm}$, the teeth gradually increase in size to two times that height, i.e. $0.034 \mathrm{~mm}$, up to the $8^{\text {th }}$, after which they remain the same until the penultimate tooth, which is followed by the smaller, $12^{\text {th }}$ tooth with a height of $0.028 \mathrm{~mm}$ (table 2).

Figs 122-131. T5 teleoconch whorls (see Fig. 1). 122, Epifungium adscabra; 123, E. hartogi; 124, E. hoeksemai; 125, E. lochi; 126, E. marki; 127, E. nielsi; 128, E. pseudolochi; 129, E. ulu; 130, E. pseudotwilae; 131, E. twilae. 122-124, Indonesia; 125, 127, 129, 131, Thailand;126, 128, Egypt; 130, Palau. Scale bar $=1$ mm. SEM Photos.
Jaw (figs 257, 262; table 2). The two jaws flanking the studied radula were studied. The denticulate edge consists of a row of slender, blunt denticles, which are basally pitted on the inside (fig. 262). They have a maximum size of $0.0018 \mathrm{~mm}$. Seen from the outside (fig. 257), 72 denticles per $0.05 \mathrm{~mm}$ extend above a $0.0060 \mathrm{~mm}$ broad, granulated jaw-flap, which lies loosely over part of the jaw-pattern. The pattern under the jaw-flap is vague, but seems to consist of at least several rows of somewhat sunken, pentagonal figures. Most of the jaw is densely pitted, but no pits are discernable directly under the jaw-flap. On the inner surface of the jaw (fig. 262), just below the denticles, there is a row of inconspicuous, engraved, scarcely pitted, irregularly square-like figures, followed by an area that is somewhat granulated to smooth.

Spawn (286-287). Egg-capsules (fig. 286) round to ovoid, without any protuberances, embedded with sand, $0.77-1.40 \mathrm{~mm}($ mean $=1.05, \mathrm{n}=12)$ in diameter, e.g. measured horizontally, from left to right in figure 286, containing 39-170 eggs (mean $=86, \mathrm{n}=$ 12) each. The mucus threads that connect the eggcapsules are straight and either smooth as in Epifungium pseudotwilae spec. nov. (fig. 295) or sculptured with longitudinal lines (fig. 287).

Habitat. The snails and their egg-capsules were found at 3-27 m, associated with Fungia (Cycloseris) costulata Ortmann, 1889, F. (C.) distorta Michelin, 1842, F. (C.) fragilis (Alcock, 1893), F. (C.) sinensis (Milne Edwards and Haime, 1851), F. (C.) somervillei Gardiner, 1909, F. (C.) tenuis Dana, 1846, or F. (C.) vaughani Boschma, 1923. They usually live attached with their mucus threads to the underside of these mushroom corals. Most host corals were found on a sandy, nearly flat bottom, situated along the lower border of a steeper coral slope.

Distribution (fig. 82). The species is known from the Indo-West Pacific, from the Maldives, Thailand, Philippines and Indonesia to Australia.

Differentiation. The shells of this species most closely resemble those of Epifungium pseudolochi spec. nov., but differ in having a less deep suture between the teleoconch whorls (figs 66-68, 105, 108, $125,128)$, and by costae, which become slightly higher, i.e. coronate, before the preceding whorl (fig. 


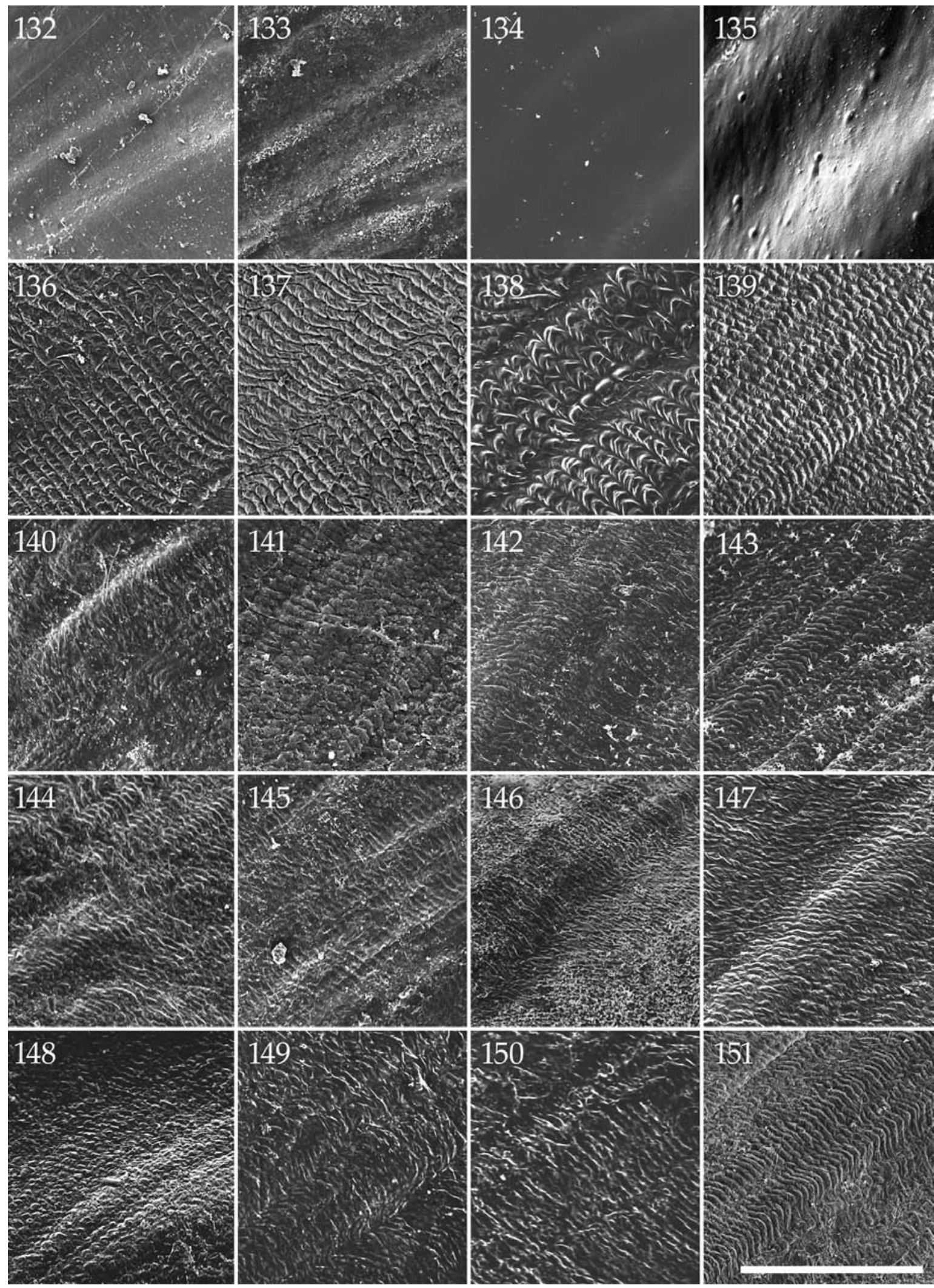


125), instead of remaining equally high and thus not at all coronate (fig. 128). Epifungium lochi also resembles E. adscabra spec. nov., E. adgravis spec. nov., E. marki spec. nov., E. nielsi spec. nov. and $E$. $u l u$ spec. nov. in shell characters, but differs by the distinct spiral threads on all teleoconch whorls, combined with a closed umbilicus. It is associated with Fungia (Cycloseris) spp. The only other epitoniid species found in association with these hosts are Epitonium crassicostatum spec. nov. and E. graviarmatum spec. nov. For comparisons with Epitonium deflersi (Jousseaume, 1911), E. oblique (Sowerby, 1844), E. zatrephes Melvill, 1910, and E. ulu Pilsbry, 1921, see A. Gittenberger et al. (2000).

Remarks. For a more detailed description of the shell and the proboscis, see A. Gittenberger et al. (2000). Here some additional data are given, with notes that may be relevant for the differentiation of this species.

\section{Epifungium marki spec. nov.}

Material (always hosted by Fungia (Pleuractis) spec. A). EGYPT. Off Marsa Shagra, about $300 \mathrm{~km} \mathrm{~S}$ of Hurghada, holotype RMNH 95082/1sh, d, with egg-capsules RMNH 100331; paratypes: type locality, RMNH 100329/2sn, found together with the holotype; off Marsa Nakari, about $350 \mathrm{~km} \mathrm{~S}$ of Hurghada, RMNH 95099/1sn, 95100/1sn.

Type locality. EGYPT. Off Marsa Shagra, about 300 $\mathrm{km} \mathrm{S}$ of Hurghada.

Shell (figs 62, 77-78, 106, 126; table 1). Shell fragile, elongate-conical, with convex whorls, creamy white; reaching $19.2 \mathrm{~mm}$ in height. For dimensions and number of costal and spiral ribs on the $2^{\text {nd }}$ and the $5^{\text {th }}$ teleoconch whorls, see table 1 . The holotype (fig. 62) measures $19.2 \times 6.6 \mathrm{~mm}$. The protoconch (fig. 106) has $3 \frac{1}{4}-3 \frac{1}{2}$ whorls $(n=5)$; apart from its smooth

Figs 132-151. Opercula. 132, 133, Epidendrium aureum; 134, E. sordidum; 135, Epitonium pyramidalis; 136 , Surrepifungium costulatum; 137, S. ingridae; 138, S. patamakanthini; 139, S. oliverioi; 140 , Epifungium adgranulosa; 141, E. adgravis; 142, E. adscabra; 143, E. hartogi; 144, E. hoeksemai; 145, E. lochi; 146, E. marki; 147, E. nielsi; 148, E. pseudolochi; 149, E. pseudotwilae; 150, E. twilae; 151, E. ulu. 132, 134, 136-138, 144, Palau; 133, 141-143, 145, 147,151, Indonesia; 135, 149, Philippines; 139, Maldives; 140, 146, 148, Egypt; 150, Thailand. Scale bar $=0.1 \mathrm{~mm}$. SEM Photos. apical part, it is sculptured with regularly spaced, very fine, incised, axial lines, $31(\mathrm{n}=1)$ per $0.2 \mathrm{~mm}$ on protoconch whorl 21/4-23/4. The teleoconch (fig. 126) has up to 10.5 whorls, separated by a very deep suture; it is sculptured with mostly regularly placed, usually discontinuous, orthocline, lamellar, not to slightly curved, low costae, not or hardly touching the adjoining whorls. Just before reaching the preceding whorl the costae become slightly coronate. The number of costae on the $2^{\text {nd }}, 3^{\text {rd }}, 5^{\text {th }}$ and younger teleoconch whorls remains approximately the same in 3 out of 4 specimens (adjoining whorls differing in about two costae); in the fourth specimen this number increases from 24 to 31 on teleoconch whorls 4 and 5. There are up to 38 costae on a whorl; on the $10^{\text {th }}$ whorl of the holotype. Very fine, irregularly placed, incised, axial lines and/or split costae are present from the $7^{\text {th }}-9^{\text {th }}$ teleoconch whorl onwards. The teleoconch is additionally sculptured with irregularly placed, relatively thick, spiral threads. From the $6^{\text {th }}-9^{\text {th }}$ teleoconch whorl onwards, there are irregularly spaced, thin, spiral threads and incised spiral lines in between and on the major spiral threads. The number of major spiral threads increases from the $2^{\text {nd }}$ to the $5^{\text {th }}$ whorl, after which it remains almost constant. From the $7^{\text {th }}-9^{\text {th }}$ whorl onwards, some of the minor spirals may gradually change into thick spiral threads. Aperture subcircular. In the $5 \mathrm{~mm}$ high specimen with $5 \frac{1}{2}$ teleoconch whorls, the umbilicus is closed; in the other four, larger specimens the umbilicus is very narrow, visible in oblique view only.

Operculum (fig. 146). Operculum paucispiral, with interconnected coils as in Surrepifungium patamakanthini spec. nov. (fig. 3). At the outside of the operculum (fig. 146) there are 34 wavy, segmented threads per $0.1 \mathrm{~mm}(\mathrm{n}=1)$, running about perpendicular to the growth lines.

Radula and Jaw. Unknown.

Spawn (figs 77, 288-289). Egg-capsules (figs 77, 288) round to ovoid, without any protuberances, embedded with sand, 1.48-1.74 $\mathrm{mm}(\mathrm{n}=2)$ in diameter, e.g. measured horizontally, from left to right in figure 288 , containing $260-270$ eggs $(n=2)$ each. The mucus threads that connect the egg-capsules are straight and not sculptured (fig. 289). 


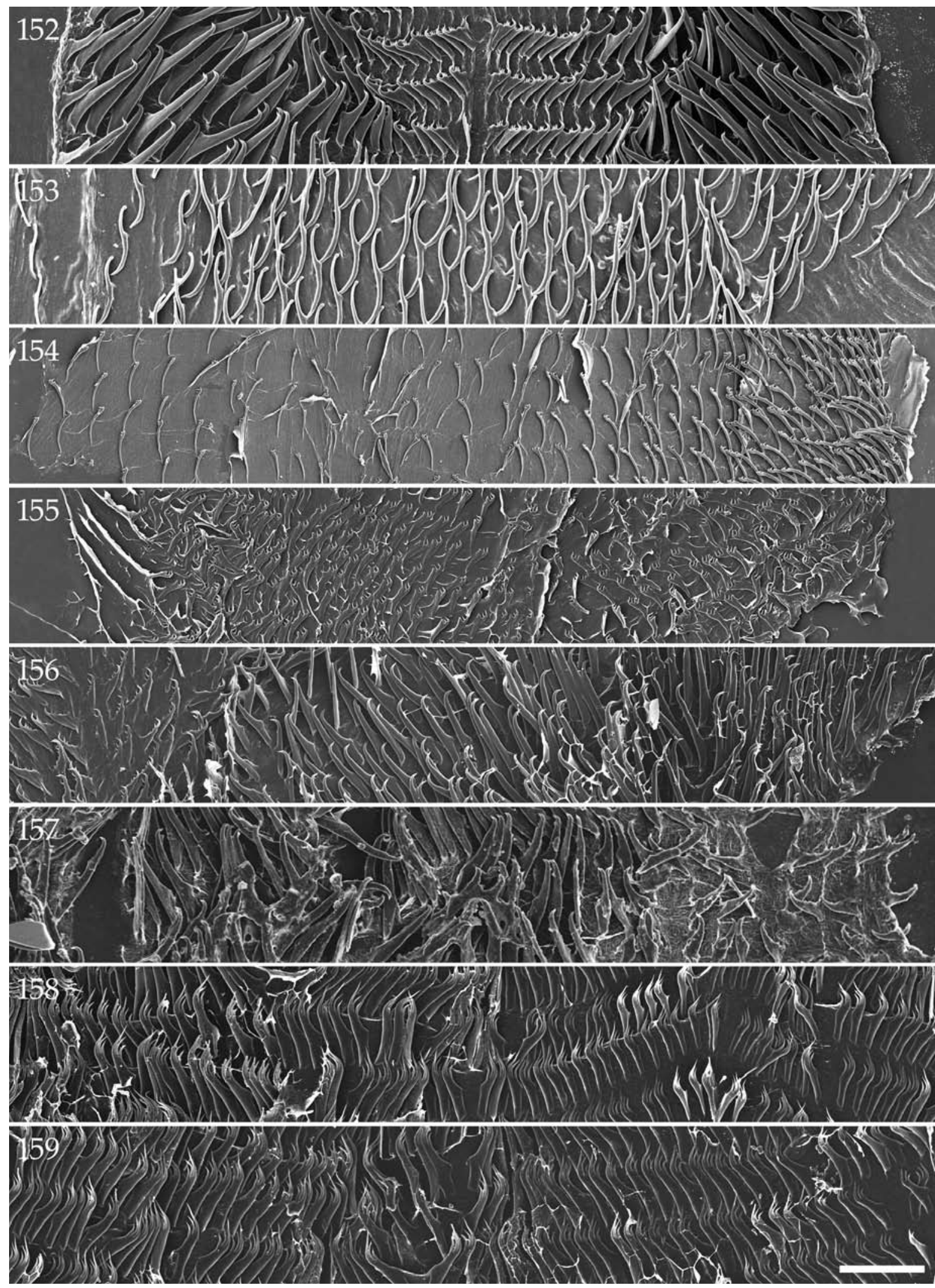


Habitat (figs 77-78). The snails and their egg-capsules were found at 15-28 m, attached with mucus threads to the underside of their hosts, which usually lay on the sand just below the lower border of a coral slope. They are associated with Fungia (Pleuractis) spec. A (figs 77-78), a mushroom coral resembling Fungia (Pleuractis) gravis Nemenzo, 1955, by its discs with a high oral hump and by preferring a similar habitat, i.e. usually deeper than 20 meters, on a sandy, nearly flat bottom, along the lower border of a steeper coral slope. Still $F$. (P.) spec. A differs from $F$. (P.) gravis, resembling other species of the subgenus Pleuractis, by the somewhat sinuous septae and the presence of numerous mouths in some specimens (fig. 78). The question how to interpret these differences, which are relevant at least for the epitoniids, is beyond the scope of this paper.

Distribution (fig. 83). The species is known from the Red Sea coast off Egypt.

Differentiation. Epifungium marki spec. nov. is the only epitoniid species that is known to be associated with Fungia (Pleuractis) spec. A. Conchologically it most closely resembles $E$. adgravis spec. nov. (see the differentiation of that species). Shells of E. marki spec. nov. also resemble those of $E$. nielsi spec. nov., but differ in more convex, somewhat broader whorls, which becomes apparent when the width of about the $3^{\text {rd }}$ teleoconch whorl is measured (table 1). Both major and minor spiral threads can be distinguished in $E$. marki spec. nov., but not in E. nielsi spec. nov. The egg-capsules of $E$. marki spec. nov. and $E$. nielsi spec. nov. differ in being smooth (fig. 288) versus with many protuberances (fig. 290), in straight (fig. 289) versus strongly twisted mucus threads (fig. 291 ), and by over 260 versus less than 137 eggs in a single egg-capsule.

Etymology. This species is named after Mark de Vries, a friend, biologist and pool specialist.

Figs 152-159. Radulae, showing at least half a row of teeth from the innermost, usually the smallest, to the ultimate teeth on the right. 152, Cirsotrema varicosa; 153 , Epitonium ancillottoi; $154, E$. spec. 1; 152-154, Sulawesi, Indonesia; 155, E. clathratulum, off Côte Basque, France; 156, E. clathrus, The Netherlands; 157, E. pyramidalis, Philippines; 158-159, Gyroscala lamellosa, Fig. 158 continues in Fig. 159, Canary Islands, Spain. Scale bar $=0.1 \mathrm{~mm}$. SEM Photos.
Remarks. The Epitonium spec. recorded from the Red Sea off Saudi Arabia by Sabelli and Taviani (1984: 91-93, figs 1-3), is probably Epifungium marki spec. nov. or E. nielsi spec. nov. The photograph of the shell is not sufficiently detailed to decide. The figured coral host (Sabelli and Taviani, 1984: fig. 2) closely resembles Fungia (Pleuractis) spec. A, but it could also be either $F$. (P.) moluccensis or $F$. (P.) seychellensis too, fungiid coral species known to be associated with $E$. nielsi spec. nov. See also the remarks on E. adgravis spec. nov. and E. ulu.

\section{Epifungium nielsi spec. nov.}

Material. Samples that were hosted by Fungia (Pleuractis) moluccensis, $F$. (P.) paumotensis, or $F$. (P.) seychellensis are coded Fm, Fp or Fs, respectively. MALDIVES. Ari Atoll, Vilamendhoo Island: House reef, $\left(03^{\circ} 38^{\prime} \mathrm{N} 72^{\circ} 57^{\prime} \mathrm{E}\right)$, holotype RMNH 100152 Fs/1sh; paratypes: type locality, RMNH $100151 \mathrm{Fs} / 1 \mathrm{sn}$, found together with holotype; Type locality, RMNH 100147 Fs/2sn, $100149 \mathrm{Fm} / 2 \mathrm{sn}+\mathrm{d}, 100148 \mathrm{Fm} / 1 \mathrm{sn}, 100141 \mathrm{Fs} / 1 \mathrm{sn}+\mathrm{d}, 100146$ Fs/1sn, $100150 \mathrm{Fs} / 2 \mathrm{sn}+\mathrm{e}, \mathrm{d}, 100144 \mathrm{Fs} / 4 \mathrm{sn}, 100143 \mathrm{Fs} / 3 \mathrm{sn}$, $100145 \mathrm{Fm} / 1 \mathrm{sn}$, d. INDONESIA. NE Kalimantan, Berau Islands, Derawan Island, E-side, Coral Garden (02¹7'32”N $118^{\circ} 15^{\prime} 43$ 'E), RMNH 100153 Fp/1sh, 3sn+e. E Sulawesi, Tomini Bay, Togian

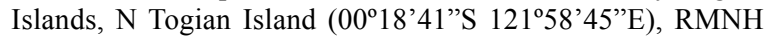
$62508 \mathrm{Fp} / 1 \mathrm{sn}+\mathrm{e}$. SW Sulawesi, Spermonde archipelago: W Bone Baku reef (0507'56'S 119²1'39'E), RMNH 95052 Fm/2sn, $43264 \mathrm{Fp} / 1 \mathrm{sn}+\mathrm{e}, 43272 \mathrm{Fp} / 1 \mathrm{sn}+\mathrm{e}, 43265 \mathrm{Fp} / 1 \mathrm{sn}, 43271 \mathrm{Fp} / 1 \mathrm{sn}+\mathrm{e}$, $43270 \mathrm{Fp} / 5 \mathrm{sn}+\mathrm{e}$; W Samalona Island (0507'31'S $\left.119^{\circ} 20^{\prime} 31^{\prime \prime} \mathrm{E}\right)$, RMNH $43202 \mathrm{Fp} / 1 \mathrm{sn}+\mathrm{e}, 43203 \mathrm{Fp} / 2 \mathrm{sn}+\mathrm{e}, 43226 \mathrm{Fp} / 2 \mathrm{sn}+\mathrm{e}$, 1sh; SW Samalona Island (05'07'42"S $\left.11^{\circ} 20^{\prime} 31^{\prime \prime} \mathrm{E}\right), \mathrm{RMNH} 43378$ $\mathrm{Fp} / 1 \mathrm{sn}+\mathrm{e}, 95079 \mathrm{Fp} / 1 \mathrm{sn}+\mathrm{e}$; E Samalona Island (0507’39”S 119²0'38'E), RMNH 43250 Fm/1sn; W Kudingareng Keke Island (0506'09"S 119 $19^{\circ}$ '09'E), RMNH 43292 Fm/1sn; S Kudingareng Keke Island (0506'21'S 119¹7'03'E), RMNH $43360 \mathrm{Fp} / 1 \mathrm{sn}$; W Bone Lola reef (0503'07'S 119'21'09'E), RMNH $43341 \mathrm{Fp} / 1 \mathrm{sn}+\mathrm{e}, 95043 \mathrm{Fp} / 1 \mathrm{sn}, 95039 \mathrm{Fp} / 1 \mathrm{sn}+\mathrm{e}, 95041$ $\mathrm{Fp} / 1 \mathrm{sn}+\mathrm{e}, 95047 \mathrm{Fp} / 1 \mathrm{sn}+\mathrm{e}$; W Badi Island (04 $58^{\circ} 05^{\prime} \mathrm{S}$ 119¹6'54'E), RMNH $95061 \mathrm{Fm} / 2 \mathrm{sn}$; Lankai Island, RMNH $43261 \mathrm{Fp} / 1 \mathrm{sn}, 43262 \mathrm{Fp} / 1 \mathrm{sn}$; NW Sumpangbinangae Island (042'ㅇ $119^{\circ} 35^{\prime}$ E), RMNH 43370 Fm/2sn+e. Sulawesi, Wakatobi National Park, Atoll outside SW Karang Kaledupa (0549'28'S 123'39'02'E), RMNH 100140/1sn+d. Bali: NE Serangan Island (08 $44^{\prime} 03^{\prime}$ 'S $115^{\circ} 15^{\prime} 05^{\prime}$ 'E), RMNH 94997 Fm/1sn; SE-end Tulamben beach (084'03"S $\left.115^{\circ} 15^{\prime} 05^{\prime \prime} \mathrm{E}\right)$, RMNH 95015 Fm/1sn, 95017 Fm/1sn+e. THAILAND. Krabi, Phiphi Islands: NW Ko Phiphi Don Island, La Nah Bay (0746’01'N 9845'42”'E), RMNH 95993 Fp/2sn, 95995 Fp/1sn; E Ko Phiphi Don Island, Poh Cape, Hin Phae $\left(07^{\circ} 43^{\prime} 30^{\prime}\right.$ 'N 9847'17'E), RMNH 96009 Fp/2sn, 95933 Fm/1sh, d, 96012 Fm/2sn+e; E Ko Phiphi Don Island, Ran Tee Bay (07\%44'59'N 9847’09”E), RMNH 95932 Fp/3sn+e, 95925 Fp/6sn, d, 95929 Fp/1sn+e; S Ko Phiphi Don, cape S of Tongsae Bay (07\%43'07'N 9846'16”E), RMNH 95867 Fm/1sn+e, 95872 Fp/6sn+e, 95875 


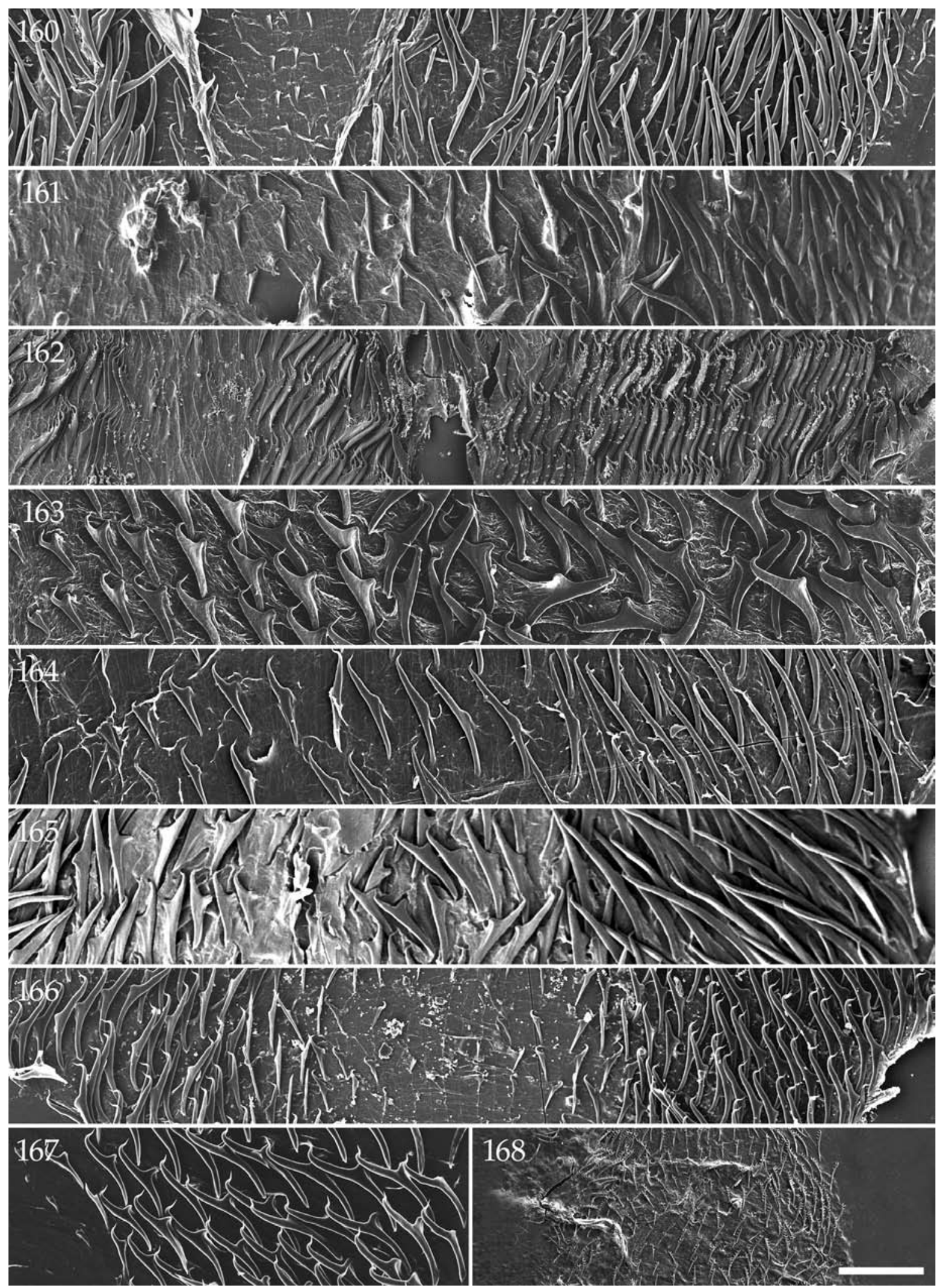


Fp/6sn+e; NW Ko Phiphi Le, Palong bay $\left(07^{\circ} 41^{\prime} 21^{\prime \prime N}\right.$ 98 45'58'E), RMNH 95879 Fp/1sh; NE Ko Phiphi Le, Pi Le Bay, near cave (07\%41'43'N 9845'57'E), RMNH 95882 Fp/4sn, 95878 Fp/ 2sn+e; W Ko Phiphi Le, N Maya Bay (0740'53'N 9845'47’E), RMNH 95962 Fp/2sn; W Ko Phiphi Le, S Maya Bay (07²0'45'N 9845'49”'E), RMNH 96005 Fm/1sn; S Ko Phiphi Le, Loh Samah (0740’28”'N 9846'10”E), RMNH 95963 Fp/1sn, 95964 Fp/1sn, $95965 \mathrm{Fp} / 1 \mathrm{sn}, 9596611 \mathrm{sn}+\mathrm{e}, 95971 \mathrm{Fp} / 3 \mathrm{sn}+\mathrm{e}, 95973$ 1sn+e, 95974 2sn, 95975 1sn+e, 959763 sn, 96004 Fp/2sn; Hin Bida, Shark point Phiphi (07³8'01'N 9848'54'E), RMNH 95956 Fm/2sn+e, 95960 Fm/1sn; Ko Bida Nok, (07³9'14”N 9845'58”E), RMNH 95911 $\mathrm{Fm} / 1 \mathrm{sn}+\mathrm{e}, 95912 \mathrm{Fp} / 2 \mathrm{sn}+\mathrm{e}, 95913 \mathrm{Fp} / 1 \mathrm{sn}, 95914 \mathrm{Fp} / 1 \mathrm{sn}, 95915$ Fp/1sn; Hin Klai, Garang Heng (07\%41'32'N 9848'35'E), RMNH $95856 \mathrm{Fm} / 1 \mathrm{sh}, 95861 \mathrm{Fm} / 3 \mathrm{sn}+\mathrm{e}, 95863 \mathrm{Fm} / 3 \mathrm{sn}, 95855 \mathrm{Fm} / 1 \mathrm{sn}$, $95858 \mathrm{Fm} / 1 \mathrm{sn}, 95859 \mathrm{Fp} / 1 \mathrm{sn}+\mathrm{e}, 95860 \mathrm{Fp} / 2 \mathrm{sn}+\mathrm{e}$, d, $95866 \mathrm{Fm} /$ $1 \mathrm{sn}+\mathrm{e}$. PALAU. NE of Ngeremdiu, Lighthouse reef, forereef (0716’30”N 134²7'25”E), RMNH 95108 Fp/1sn, 95114 Fp/1sn, $95133 \mathrm{Fp} / 1 \mathrm{sn}$.

Type locality. MALDIVES. Ari Atoll, Vilamendhoo Island.

Shell (figs 65, 107, 127; table 1). Shell fragile, elongate-conical, with rather convex whorls, creamy white; reaching $17.5 \mathrm{~mm}$ in height. For dimensions and number of costal and spiral ribs on the $2^{\text {nd }}$ and the $5^{\text {th }}$ teleoconch whorls, see table 1 . The holotype (fig. 65) measures $14.0 \times 5.9 \mathrm{~mm}$. The protoconch (fig. 107) has 31/4-31/2 whorls $(n=10)$; apart from its smooth apical part, it is sculptured with regularly spaced, very fine, incised, axial lines, $22(\mathrm{n}=1)$ per $0.2 \mathrm{~mm}$ on protoconch whorl $2 \frac{1 / 4}{4}-2 \frac{3}{4}$. The teleoconch (fig. 127) has up to 11 whorls, separated by a moderately deep suture; it is sculptured with mostly regularly placed, usually not continuous, orthocline, lamellar, not or slightly curved, low costae, not or hardly touching the adjoining whorls. Shortly before reaching the preceding whorl the costae become slightly coronate. The number of costae on the $2^{\text {nd }}$, $3^{\text {rd }}, 5^{\text {th }}$ and younger teleoconch whorls usually remains approximately the same (adjoining whorls differing in about two costae); it only increases on

Figs 160-168. Radulae, showing at least half a row of teeth from the innermost, usually the smallest, to the ultimate teeth on the right; $\mathrm{sh}=$ shell height. 160-161, Epidendrium aureum spec. nov.; 160 , sh $=11.8 \mathrm{~mm}$, Sulawesi, Indonesia; 161 , sh $=14.9 \mathrm{~mm}$, Thailand; 162, E. sordidum spec. nov., holotype, $\mathrm{sh}=16.0 \mathrm{~mm}$, Indonesia; 163-164, Surrepifungium costulatum; 163 , sh $=31.6 \mathrm{~mm}$, Sulawesi, Indonesia; 164, sh = $26.1 \mathrm{~mm}$, Palau; 165, S. oliverioi, $\mathrm{sh}=18.1 \mathrm{~mm}$, Maldives; 166, S. ingridae, Sulawesi, Indonesia; 167, S. patamakanthini spec. nov., Palau; 168, Epifungium lochi, Sulawesi, Indonesia. Scale bar $=0.1 \mathrm{~mm}$. SEM Photos. the younger whorls in about a third of the shells, up to 41 costae on the $10^{\text {th }}$ whorl in a shell of $14.0 \mathrm{~mm}$ in height. The teleoconch is additionally sculptured with randomly placed, low, spiral threads, which are obsolete on the $1^{\text {st }}$ and $2^{\text {th }}$ teleoconch whorl in about a third of the specimens. Towards the younger whorls, additional low, spiral threads become apparent. In about one third of the specimens they are numerous from about the $8^{\text {th }}$ teleoconch whorl onwards. Aperture subcircular. Most specimens $(\mathrm{n}=31)$ have a very narrow umbilicus, visible in oblique view only. Only one specimen has the umbilicus closed.

Operculum (fig. 147). Operculum paucispiral, with interconnected coils as in Surrepifungium patamakanthini spec. nov. (fig. 3). At the outside of the operculum (fig. 147) there are 28-29 wavy, segmented threads per $0.1 \mathrm{~mm}(\mathrm{n}=2)$, running about perpendicular to the growth lines.

Radula (figs 172, 192, 212; table 2). Only one radula could be studied (fig. 172; table 2). Each tooth (figs $172,192)$ consists of a moderately slender stem and a somewhat broader blade, which merge gradually; the blade has 1-6 acute, secondary cusps. The teeth (figs 160-161) are attached to the radular plate along the bases, which takes about half of the length of a tooth (fig. 202). The number of secondary cusps (table 2) gradually increases from 1 on the innermost tooth (fig. 192, left) to 6 on the $11^{\text {th }}$ and the $12^{\text {th }}$ tooth, after which the number gradually decreases to 1 on the ultimate, i.e. $20^{\text {th }}$ tooth (fig. 172, upper right corner). The apical cusp and the secondary cusp directly underneath it are usually similar in size and somewhat curved towards each other; all other secondary cusps are slightly smaller, similar to each other in size, and usually not curved (fig. 212). Starting from the innermost, smallest tooth, with a height of $0.035 \mathrm{~mm}$, the teeth gradually increase in size to about $1 \frac{1}{2}$ times that height, i.e. $0.056 \mathrm{~mm}$, up to the $12^{\text {th }}$ tooth, after which they gradually become somewhat smaller until the penultimate, $0.048 \mathrm{~mm}$ high $19^{\text {th }}$ tooth, which is followed by the, usually malformed, much smaller ultimate tooth, with a height of $0.037 \mathrm{~mm}$ (table 2).

Jaw (figs 258, 263; table 2). Only one jaw was studied. The denticulate edge consists of a row of slender, blunt denticles, which are basally pitted on the inside 


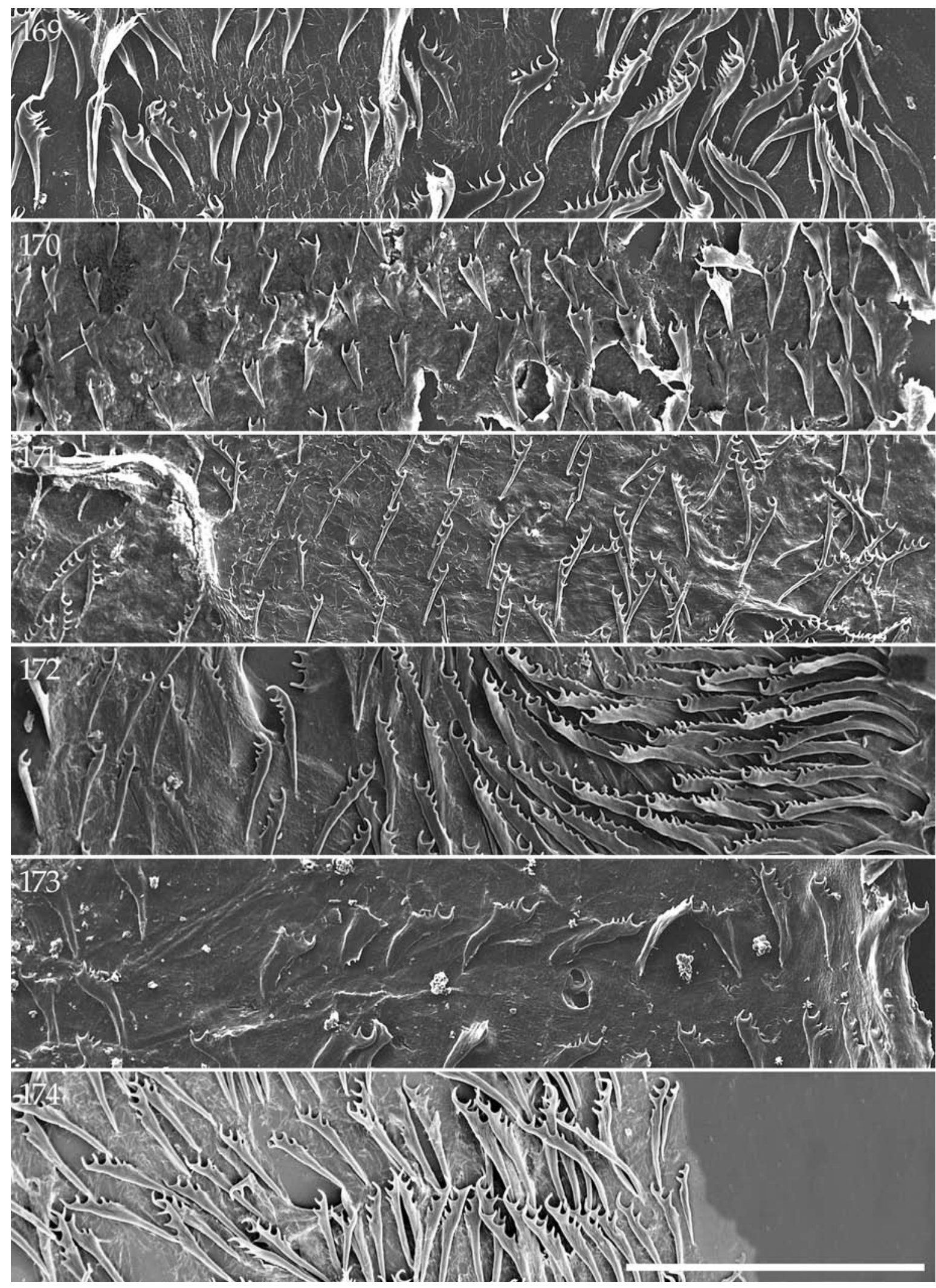


(fig. 263). They have a maximum size of $0.0030 \mathrm{~mm}$. Seen from the outside (fig. 258), 71 denticles per 0.05 $\mathrm{mm}$ extend above a $0.0142 \mathrm{~mm}$ broad, granulated jaw-flap, which lies loosely over part of the jaw-pattern. The pattern under the jaw-flap consists of at least 11 rows of somewhat sunken, pentagonal figures, of which the upper four to five rows are densely pitted, while the others are not. On the inner surface of the jaw (fig. 263), just below the denticles, there is a row of engraved, scarcely pitted, irregularly square-like figures, followed by an area that is somewhat granulated to smooth.

Spawn (figs 290-291). Egg-capsules (fig. 290) ovoid, with distinct protuberances, sometimes embedded with sand, 0.66-1.34 mm (mean $=1.06, \mathrm{n}=$ 18 ) in diameter, e.g. measured horizontally, from left to right in figure 290, containing 75-137 eggs (mean $=105.5, \mathrm{n}=17$ ) each. The mucus threads that connect the egg-capsules are strongly twisted and not sculptured (fig. 291).

Habitat. The snails and their egg-capsules were found at 4-36 m, associated with Fungia moluccensis Van der Horst, 1919, F. paumotensis Stutchbury, 1833, and $F$. seychellensis Hoeksema, 1993. They usually live attached with their mucus threads to the underside of these mushroom corals or to a hard substratum underneath. Most host corals were found on coral slopes. Rarely they were also seen on the sandy substratum underneath a coral slope.

Distribution (fig. 84). The species is known from the Indo-West Pacific, from Maldives, Thailand and Indonesia to Palau.

Differentiation. Conchologically this species resembles Epifungium adgravis spec. nov. and E. marki spec. nov. See the differentiation of those species.

Etymology. This species is named after Niels Schrieken, a friend, scuba-diver and biologist, who assisted

Figs 169-174. Radulae, showing at least half a row of teeth from the innermost, usually the smallest, to the ultimate teeth on the right. 169, Epifungium hartogi; 170, E. hoeksemai; 171, E. lochi; 172, E. nielsi spec. nov.; 173, E. twilae; 174, E. ulu. 169-174, Indonesia; 169-171, 173-174, Sulawesi; 172, Kalimantan. Scale bar $=0.1 \mathrm{~mm}$. SEM Photos. in the fieldwork and collected many of the specimens of this new species.

Remarks. See the remarks on Epifungium adgravis spec. nov., E. marki spec. nov. and E. ulu.

Epifungium pseudolochi spec. nov.

Material (always hosted by Fungia (Cycloseris) costulata Ortmann, 1889). EGYPT. Off Marsa Nakari, about $350 \mathrm{~km} \mathrm{~S}$ of Hurghada, holotype RMNH 95358/1sh, d, with egg-capsules RMNH 100328; paratypes: type locality, RMNH 95355/1sn, 95356/1sn, 95357/1sn+e, 95259/1sn.

Type locality. EGYPT. Off Marsa Nakari, about 350 $\mathrm{km} \mathrm{S}$ of Hurghada.

Shell (figs 68, 108, 128; table 1). Shell fragile, elongate-conical, with convex whorls, creamy white; reaching $6.6 \mathrm{~mm}$ in height. For dimensions and number of costal and spiral ribs on the $2^{\text {nd }}$ and the $5^{\text {th }}$ teleoconch whorls, see table 1 . The holotype (fig. 68) measures $6.6 \times 2.2 \mathrm{~mm}$. The protoconch (fig. 108) has 31/4-31/2 whorls $(n=5)$; apart from its smooth apical part, it is sculptured with regularly spaced, very fine, incised, axial lines, $23(\mathrm{n}=1)$ per $0.2 \mathrm{~mm}$ on protoconch whorl

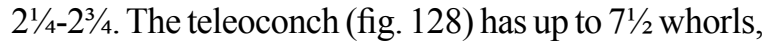
separated by a very deep suture; it is sculptured with mostly regularly placed, usually discontinuous, orthocline, lamellar, not or slightly curved, low costae, not or hardly touching the adjoining whorls. The costal ribs remain similar in height along the entire whorl. The number of costae is similar on all whorls (table 1). There are up to 27 costae on a whorl; on the $7^{\text {th }}$ whorl in a shell of $6.6 \mathrm{~mm}$ in height. The teleoconch is additionally sculptured with very low, distinct, evenly distributed spiral threads. The number of spiral threads gradually increases towards the younger teleoconch whorls (table 1). Aperture subcircular. The umbilicus is closed.

Operculum (fig. 148). Operculum paucispiral, with interconnected coils as in Surrepifungium patamakanthini spec. nov. (fig. 3). At the outside of the operculum (fig. 148) there are 25 wavy, segmented threads per $0.1 \mathrm{~mm}(\mathrm{n}=1)$, running about perpendicular to the growth lines.

Radula and Jaw. Unknown. 


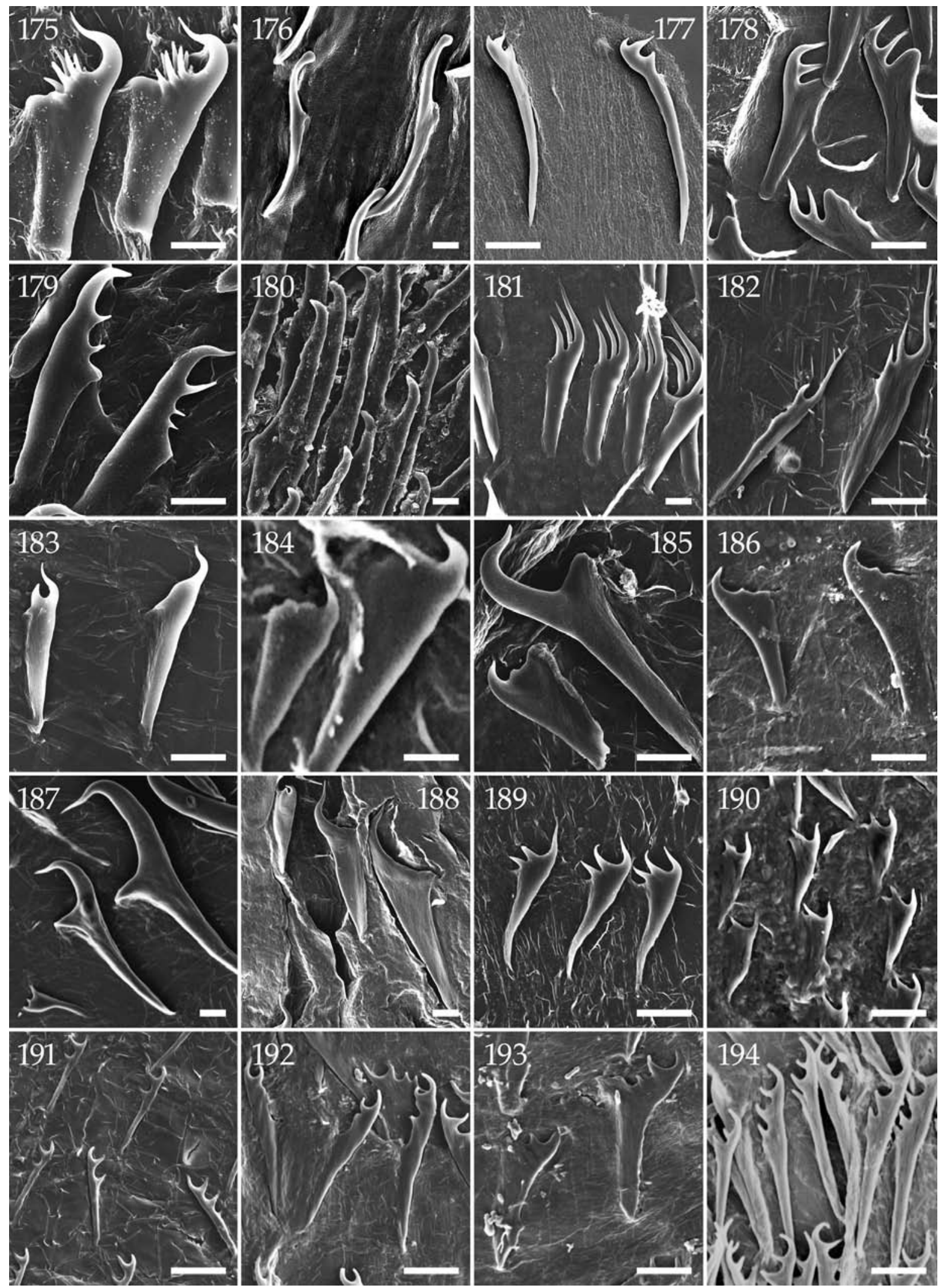


Spawn (figs 292-293). Egg-capsules (fig. 292) round to ovoid, without any protuberances, embedded with sand, 0.92-0.97 $\mathrm{mm}(\mathrm{n}=2)$ in diameter, e.g. measured horizontally, from left to right in figure 292, containing 45-45 eggs $(\mathrm{n}=2)$ each. The mucus threads that connect the egg-capsules are straight and not sculptured (fig. 293).

Habitat. The snails and their egg-capsules were found at $20-30 \mathrm{~m}$, associated with exclusively the mushroom coral species Fungia (Cycloseris) costulata Ortmann, 1889. The snails live attached with their mucus threads to the underside of their hosts. The host corals were found on a sandy, nearly flat bottom, situated along the lower border of a steeper coral slope.

Distribution (fig. 82). The species is known from the Red Sea coast off Egypt.

Differentiation. The shells most closely resemble those of Epifungium lochi. See the differentiation of that species.

Remarks. Even though its shells most closely resemble those of Epifungium lochi, molecular analyses (A. Gittenberger et al., in prep.) indicate that $E$. pseudolochi spec. nov. is more closely related to $E$. adgravis spec. nov., E. adscabra spec. nov., E. marki spec. nov. and E. nielsi spec. nov., than to E. lochi.

\section{Epifungium pseudotwilae spec. nov.}

Epitonium bullatum (Sowerby, 1844); Yamashiro, 1990: 299, figs 1-6. Not Scalaria bullatum Sowerby, 1844.

Material. Samples that were hosted by Podabacia crustacea, Sandalolitha dentata, S. robusta, or Zoopilus echinatus are coded Pc, Sd, Sr, or Ze, respectively. PALAU. NE of Ngeremdiu,

Figs 175-194. Innermost teeth of radulae in Figs 152-174. 175, Cirsotrema varicosa; 176, Epitonium ancillottoi; 177, E. spec. $1 ; 178$, E. clathratulum; 179, E. clathrus; 180, E. pyramidalis; 181, Gyroscala lamellosa; 182, Epidendrium sordidum; 183, E. aureum; 184-185, Surrepifungium costulatum; 184, radula in Fig. 164; 185, radula in Fig. 163; 186, S. ingridae; 187, S. patamakanthini; 188, S. oliverioi; 189, Epifungium hartogi; 190, E. hoeksemai; 191, E. lochi; 192, E. nielsi; 193, E. twilae; 194, E. $u l u$. Scale bars $=0.01 \mathrm{~mm}$. SEM Photos.
Lighthouse reef, forereef ( $\left.07^{\circ} 16^{\prime} 30^{\prime \prime} \mathrm{N} 134^{\circ} 27^{\prime} 25^{\prime \prime} \mathrm{E}\right)$, holotype RMNH $95190 \mathrm{Sr} / 1 \mathrm{sh}$; paratypes: type locality, RMNH 95181 $\mathrm{Sr} / 1 \mathrm{sn}+\mathrm{e}, 95183 \mathrm{Sr} / 1 \mathrm{sn}, 95184 \mathrm{Sr} / 1 \mathrm{sh}, 1 \mathrm{sn}, 95190 \mathrm{Sr} / 1 \mathrm{sn}+\mathrm{e} ; \mathrm{N}$ of Ngeremdiu, Lighthouse reef, backreef $\left(07^{\circ} 17^{\prime} 11^{\prime \prime} \mathrm{N}\right.$ 134'27'26”E), RMNH 95182 Sr/1sn; SW of Ngemelachel Passage, S of Ngchesechang, off mangrove $\left(07^{\circ} 23^{\prime} 35^{\prime \prime} \mathrm{N}\right.$ 134'35'30”E), RMNH $95187 \mathrm{Sr} / 1 \mathrm{sn}$; E of Babelthuap, E of Arudowaishi Pt., Uchelbeluu, backreef (07²1'20'”N 134³6'22'E), RMNH $95188 \mathrm{Sr} / 1 \mathrm{sn}+\mathrm{e}$. MALDIVES. Ari Atoll, Vilamendhoo Island: House reef, $\left(03^{\circ} 38^{\prime} \mathrm{N} 72^{\circ} 57^{\prime} \mathrm{E}\right), \mathrm{RMNH} 100162 \mathrm{Sd} / 1 \mathrm{sn}$, $100163 \mathrm{Sd} / 2$ sn, $100174 \mathrm{Sd} / 2$ sn. PHILIPPINES. Cebu Strait: Olango Channel, E Olanga Island (10¹5'32'N 12404'11'E), RMNH 100164 Sd/2sn+e; W Bohol, NW Cabilao Island, Baluarte Point (953'N 12345' E), RMNH 100156 Sr/3sn+e, r; W Bohol, SW Sandingan Island (0950'36”N 12347'17'E), RMNH 100155 $\mathrm{Sr} / 1 \mathrm{sn}$. INDONESIA. NE Kalimantan, Berau Islands: E Derawan Island, Coral Garden (02 ${ }^{\circ} 17^{\prime} 32^{\prime \prime} N 118^{\circ} 15^{\prime} 43$ 'E), RMNH 100158 Ze/1sn; S Derawan Island, jetty Derawan Dive Resort ( $02^{\circ} 17^{\prime} 03^{\prime} \mathrm{N}$ 11814'49'E), RMNH 100159 Podabacia spec./2sn+e; N Maratua Island, lagoon near entrance $\left(02^{\circ} 14^{\prime} 53^{\prime \prime} \mathrm{N} 118^{\circ} 37^{\prime} 36^{\prime \prime} \mathrm{E}\right)$, RMNH $100173 \mathrm{Sr} / 3 \mathrm{sn}+\mathrm{e}$; N Sangalaki Island $\left(02^{\circ} 05^{\prime} 25^{\prime \prime} \mathrm{N}\right.$ 118 24'16”E), RMNH $100157 \mathrm{Sd} / 1 \mathrm{sn}+\mathrm{e}$; Panjang Island, S of Sharkpoint (02'18'34'N 118 15'16"E), RMNH 100161 Ze/4sn; $\mathrm{N}$ Panjang Island, NE Baliktaba reef ( $\left.02^{\circ} 35^{\prime} 15^{\prime \prime} \mathrm{N} 118^{\circ} 00^{\prime} 35^{\prime} \mathrm{E}\right)$, RMNH 100160 Ze/1sn. N Sulawesi, Off Manado, Siladen Island (01'37'37'N 12448'01'"E), RMNH 100154 Sr/1sn. E Sulawesi, Tomini Bay, Togian Islands: N Togian Island $\left(00^{\circ} 18^{\prime} 41^{\prime} \mathrm{S}\right.$ 121 $\left.{ }^{\circ} 58^{\prime} 45^{\prime \prime E}\right)$, RMNH 100166 Sr/2sn, 100167 Sr/2sn, 100169 $\mathrm{Sr} / 1 \mathrm{sh}, 1 \mathrm{sn}, 100168 \mathrm{Sr} / 3 \mathrm{sn} ; \mathrm{S}$ Togian Island $\left(00^{\circ} 20^{\prime} 10^{\prime \prime S}\right.$ 12159'00”E), RMNH 100170 Sr/2sh. SW Sulawesi, Spermonde archipelago: W Lae Lae Island (0508'09"S 119²3'13"E), RMNH 59148 Sr/2sn+e, 59149 Sr/1sn; NW Bona Baku reef (0507'56”S 119²1'39”'E), RMNH $43380 \mathrm{Sr} / 1 \mathrm{sn}, 95166$ Pc/2sn, $95167 \mathrm{Sr} / 1 \mathrm{sn}+\mathrm{e}$; W Samalona Island (0507’31'S 119²0’31”E), RMNH $59117 \mathrm{Sr} / 1 \mathrm{sn}+\mathrm{e}, 59136 \mathrm{Sr} / 1 \mathrm{sh}$; SW Samalona Island (0507'42”S 119²0'31'E), RMNH 95176 Sr/1sn+e; E Samalona Island (0507'28'S $\left.119^{\circ} 20^{\prime} 38^{\prime \prime} \mathrm{E}\right), \mathrm{RMNH} 59131 \mathrm{Sr} / 4 \mathrm{sn}, 59139$ $\mathrm{Sr} / 1 \mathrm{sn}+\mathrm{e}, 59140 \mathrm{Sr} / 1 \mathrm{sh}, 4 \mathrm{sn}+\mathrm{e}$. W Bone Lola reef (05'03'07'’S 119²1'09'E), RMNH $59161 \mathrm{Sr} / 2 \mathrm{sn}+\mathrm{e}, 95162 \mathrm{Sr} / 3 \mathrm{sn}+\mathrm{e}, 95163$ $\mathrm{Sr} / 6 \mathrm{sn}+\mathrm{e}, 100165 \mathrm{Sr} / 1 \mathrm{sn}, \mathrm{o}$. SW Barang Lompo Island $\left(05^{\circ} 03^{\prime} \mathrm{S}\right.$ $\left.119^{\circ} 20^{\prime} \mathrm{E}\right), \mathrm{RMNH} 100171 \mathrm{Sr} / 2 \mathrm{sn}+\mathrm{e}, 100172 \mathrm{Sr} / 1 \mathrm{sn}+\mathrm{e}$; NW Kudingareng Keke Island (05'06'08'S 119¹7'17'E), RMNH 43389 Sd/2sn, 59152 Ze/1sn; W Kudingareng Keke Island (0506'09'S 119¹7'09”'E), RMNH 59106 Sr/1sh, 59124 Sr/1sh, $59115 \mathrm{Sr} / 3 \mathrm{sn}+\mathrm{e}, 59110 \mathrm{Ze} / 1 \mathrm{sn}, 59111 \mathrm{Ze} / 2 \mathrm{sn}+\mathrm{e}, 59112 \mathrm{Ze} / 1 \mathrm{sn}$; SE Kudingareng Keke Island (0506'S 119 17'E), RMNH 59151 $\mathrm{Sr} / 1 \mathrm{sh}$; W Badi Island (04'58'05"S 119¹6'54”E), RMNH 43390 Ze/1sn, 95171 Ze/2sn, 59159 Sd/5sn+e; NW Bone Tambung Island (0502'05'S 119¹6'16”E), RMNH 59119 Ze/1sh, 59155 Ze/2sh, $59157 \mathrm{Sd} / 1 \mathrm{sh}$; SW Bone Tambung Island (0502'12”S 119¹6'19”'E), RMNH 43388 Ze/2sn, 59154 Ze/2sn, 59156 Ze/1sn, 59158 Ze/1sn+e; W Lankai Island, $59137 \mathrm{Sr} / 1$ sh. Moluccas, Ambon, Hitu, Ambon bay, outer bay, N coast, W of Sahuru ( $03^{\circ} 40^{\prime} \mathrm{S}$ $\left.128^{\circ} 09^{\prime} \mathrm{E}\right), \mathrm{RMNH} 83488$ host unknown/2sn+e. Bali, off Sanur: Loloan Batu Agung (0843'31'S 115¹5'57’E), RMNH 95156

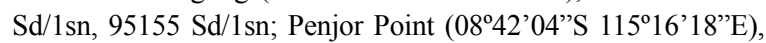
RMNH 95153 Sd/1sn, 95152 Sd/1sn, 95154 Sd/1sn. 


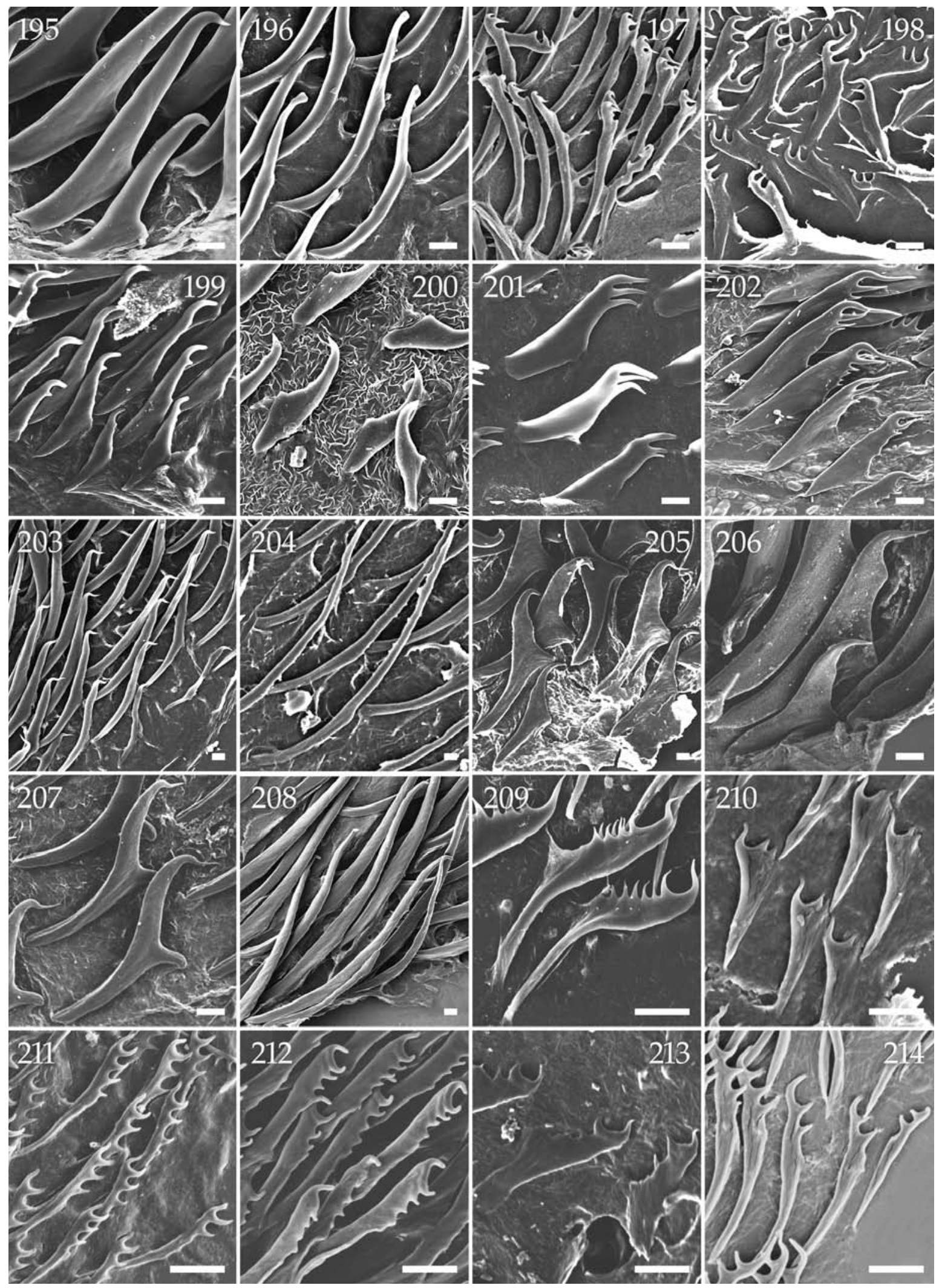


Type locality. PALAU. NE of Ngeremdiu, Lighthouse reef, forereef $\left(07^{\circ} 16^{\prime} 30^{\prime \prime} \mathrm{N} 134^{\circ} 27^{\prime} 25^{\prime \prime} \mathrm{E}\right)$.

Shell (figs 90-91, 109, 130; table 1). Shell fragile, more broadly conical than most other epitoniid shells, with flattened to slightly convex whorls, creamy white; reaching $18.5 \mathrm{~mm}$ in height. For dimensions and number of costal and spiral ribs on the $2^{\text {nd }}$ and the $5^{\text {th }}$ teleoconch whorls, see table 1 . The holotype (fig. 90) measures $14.2 \times 10.0 \mathrm{~mm}$. The protoconch (fig. 109) has 31/4-31/2 whorls $(\mathrm{n}=$ 10); apart from its smooth apical part, it is sculptured with regularly spaced, very fine, incised, axial lines, $17(\mathrm{n}=1)$ per $0.2 \mathrm{~mm}$ on protoconch whorl $2 \frac{1}{4}-2^{3} / 4$. In almost all shells the protoconch is seriously damaged, with missing whorls, or very strongly eroded. Protoconchs that still show axial lines are rare $(1$ out of 40). The teleoconch (fig. 130) has up to $81 / 2$ whorls, separated by a somewhat indented suture; it is sculptured with mostly regularly placed, usually discontinuous, orthocline, lamellar, not or slightly curved, very low costae, which are not or hardly touching the adjoining whorls. The number of costae on the $2^{\text {nd }}, 3^{\text {rd }}, 5^{\text {th }}$ and younger teleoconch whorls usually increases considerably. There are up to 65 costae on a whorl; on the $8^{\text {th }}$ whorl in a shell of $14.2 \mathrm{~mm}$ in height. The teleoconch is additionally sculptured with numerous, inconspicuous spiral threads, which are usually obsolete on the initial whorls. Aperture rather roundish, its border curved in such a way that the parietal interruption is shorter than each of the three other sides, i.e. the palatal, basal and columellar side, which very gradually change into one another. Umbilicus clearly open, quickly narrowing inside.

Operculum (fig. 149). Operculum paucispiral, with interconnected coils as in Surrepifungium patamakanthini spec. nov. (fig. 3). At the outside of the

Figs 195-214. Outermost teeth of radulae in Figs 152-174. 195, Cirsotrema varicosa; 196, Epitonium ancillottoi; 197, E. spec. 1; 198, E. clathratulum; 199, E. clathrus; 200, E. pyramidalis; 201, Gyroscala lamellosa; 202, Epidendrium sordidum; 203, E. aureum; 204-205, Surrepifungium costulatum; 204, radula in Fig. 164; 205, radula in Fig. 163; 206, S. ingridae; 207, S. patamakanthini; 208, S. oliverioi; 209, Epifungium hartogi; 210, E. hoeksemai; 211, E. lochi; 212, E. nielsi; 213, E. twilae; 214, E. ulu. Scale bars $=0.01 \mathrm{~mm}$. SEM Photos. operculum (fig. 149) there are 22 wavy, segmented threads per $0.1 \mathrm{~mm}(\mathrm{n}=1)$, running about perpendicular to the growth lines.

Radula (figs 173, 193, 213; table 2). Only one radula could be studied (fig. 173; table 2). Each tooth (figs 193, 213) consists of a moderately broad stem and a somewhat broader blade; the blade has 2-4 acute, secondary cusps. Where the stem and the blade merge, the blade usually curves away, standing almost perpendicular to the radular plate (fig. 193, right). The teeth (figs 173, 193, 213) are attached to the radular plate along the bases, which takes half to two third of the length of a tooth (fig. 202). The number of secondary cusps (table 2) gradually increases from 1 on the innermost tooth (fig. 193 , left) to 4 on the $4^{\text {th }}$ and $5^{\text {th }}$ teeth, after which the number gradually decreases to 2 on the $7^{\text {th }}$ tooth, which is followed by the $8^{\text {th }}-11^{\text {th }}$ teeth with 3 secondary cusps (fig. 213). The apical cusp and the secondary cusp directly underneath it are usually similar in size and somewhat curved towards each other; all other secondary cusps are slightly smaller, similar to each other in size, and usually not curved (fig. 173). Starting from the innermost, smallest tooth, with a height of $0.029 \mathrm{~mm}$, the teeth gradually increase in size to almost $1 \frac{1}{2}$ times that height, i.e. $0.041 \mathrm{~mm}$, up to the $5^{\text {th }}$ tooth, after which they gradually become somewhat smaller until the ultimate, i.e. $11^{\text {th }}$ tooth, measuring $0.028 \mathrm{~mm}$ in height (table 2).

Jaw. Unknown.

Spawn (figs 294-295). Egg-capsules (fig. 294) ovoid, somewhat transparent, smooth or with small protuberances, not embedded with sand, $1.08-2.15 \mathrm{~mm}$ (mean $=1.62, \mathrm{n}=17$ ) in diameter, e.g. measured horizontally, from left to right in figure 294, containing 250-650 eggs (mean $=434.4, \mathrm{n}=15)$ each. The mucus threads that connect the egg-capsules are straight and not sculptured (fig. 295).

Habitat. The snails and their egg-capsules were found at 4-25 m depth, associated with Podabacia crustacea (Pallas, 1766), Sandalolitha robusta (Quelch, 1886), S. dentata Quelch, 1884 and Zoopilus echinatus Dana, 1846. They usually live on the underside of these mushroom corals, attached with their mucus 


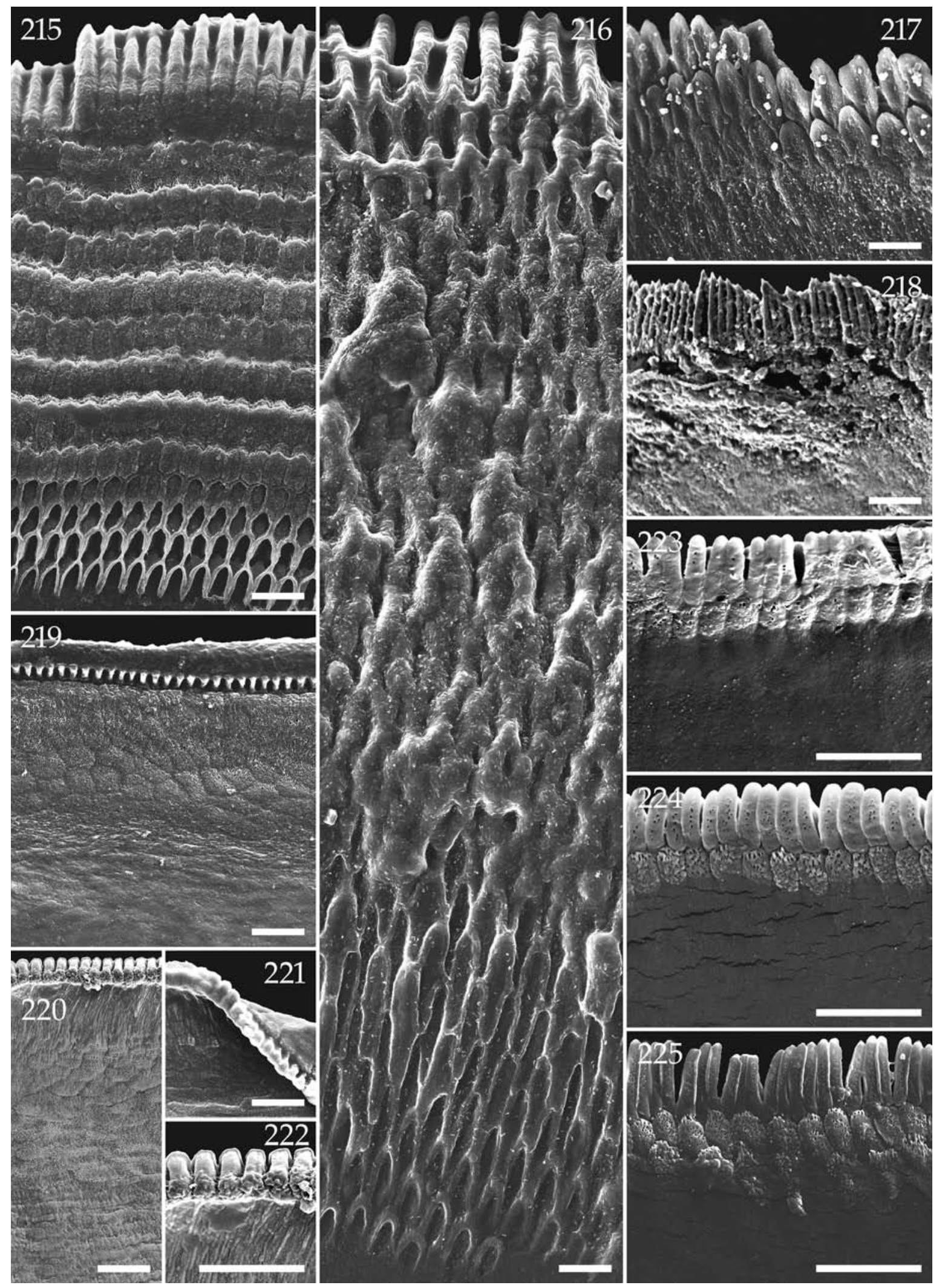


threads. The host corals were found on a coral slope or on a sandy bottom bordering a coral slope.

Distribution (fig. 85). This species is known from the Indo-West Pacific, from Maldives, Philippines and Indonesia to Palau.

Differentiation. Conchologically Epifungium pseudotwilae spec. nov. closely resembles E. twilae, from which it differs however, in having on average 20 instead of 26 costae on the $2^{\text {nd }}$ teleoconch whorl, an average T3 value of 0.91 versus $0.97 \mathrm{~mm}$, and not more than 65 costae on a whorl instead of over 80 from the $7^{\text {th }}$ teleoconch whorl onwards. There is a slight difference also in the form of the aperture, i.e. the parietal, palatal, basal and columellar sides are about equally long in E. twilae (figs 88-89), while the parietal side is relatively shorter in E. pseudotwilae spec. nov. (figs 90-91). Their habitat preferences also differ; E. pseudotwilae spec. nov. is associated with Podabacia crustacea, Sandalolitha robusta, S. dentata and Zoopilus echinatus, while $E$. twilae is associated with Ctenactis crassa, C. echinata and Herpolitha limax.

Etymology. Conchologically this species very much resembles Epifungium twilae, hence the epitheton pseudotwilae.

Remarks. It seems that in both Epifungium pseudotwilae spec. nov. and E. twilae, there are many more broken and strongly eroded protoconchs than in the other epitoniids that are associated with corals.

All paratypes of E. twilae that were found associated with Sandalolitha robusta and Zoopilus echinatus, have now been identified as E. pseudotwilae spec. nov. The epitoniid species collected in the Red Sea off Thomas Reef, Sinai, and identified as E. bullatum by Dushane (1988a: 30, figs 5, 6) is either E. twilae or E. pseudotwilae spec. nov. (see also A. Gittenberger et al., 2000); because the host species is un-

Figs 215-225. Details of jaws flanking radulae in Figs 152-155, 157-159. 215, Cirsotrema varicosa; 216-217, Gyroscala lamellosa; 218, Epitonium pyramidalis; 219, E. ancillottoi; 220-222, E. spec. 1; 223-225, E. clathratulum. 215-216, 218-223, jaw, outer surface; 217, 224-225, jaw, inner surface; 221, lower left: outer surface of jaw, upper right: inner surface. Scale bars $=0.01$ mm. SEM Photos. known and since the specimen could not be studied in detail, it is impossible to conclude to which of these two species it belongs. See A. Gittenberger et al. (2000) for a comparison of "Epitonium twilae" with Epitonium bullatum.

Epifungium twilae (A. Gittenberger and Goud, 2000)

Epitonium twilae A. Gittenberger and Goud, 2000: 10-11, figs $19,28,32-33,48$.

Material. INDONESIA (hosted by Ctenactis crassa, C. echinata and Herpolitha limax). SW Sulawesi, Spermonde archipelago: holotype (hosted by H. limax) RMNH 59104 and 43 paratypes with 10 clutches of egg-capsules: RMNH 59105, 59107-59109, 59113, 59114, 59116, 59118, 59121-59123, 59126, 59127, 59129, 59132-59135, 59138, 59141-59143, 59145-59147, 59150, 59153, 59160, 59163. Additionally studied material: 17 specimens, 12 clutches of egg-capsules, 4 d, 1 r. Central Sulawesi, Donggala, Pasikewa, W of Towale: 1 specimen, 1 clutch of egg-capsules. NE Komodo: 1 specimen, $1 \mathrm{~d}$. Moluccas, Ambon (hosted by $H$. limax), 3 specimens, 1 clutch of egg-capsules, $2 \mathrm{~d}$. EGYPT (hosted by $H$. limax). Off Marsa Shagra, about $350 \mathrm{~km} \mathrm{~S}$ of Hurghada: 5 specimens, 3 clutches of egg-capsules, 2 d. MALDIVES. Ari Atoll, off Vilamendhoo Island (hosted by H. limax), 10 specimens, 1 clutch of egg-capsules, 1 d. THAILAND. Krabi, Phiphi Islands (hosted by C. crassa, C. echinata and H. limax), 47 specimens, 14 clutches of egg-capsules, $1 \mathrm{~d}$. AUSTRALIA. Queensland, Lizard Island (hosted by H. limax), from the Australian Museum, Sydney (AMS 99806), 1 specimen.

Type locality. INDONESIA. SW Sulawesi, Spermonde archipelago.

Shell (figs 88-89, 110, 131; table 1). Shell fragile, more broadly conical than most other epitoniid shells, with slightly convex whorls, creamy white; reaching $20.8 \mathrm{~mm}$ in height. For dimensions and number of costal and spiral ribs on the $2^{\text {nd }}$ and the $5^{\text {th }}$ teleoconch whorls, see table 1 . The holotype (fig. 89) measures $14.4 \times 9.0 \mathrm{~mm}$. The protoconch (fig. 110) has $3 \frac{114-31 / 2}{2}$ whorls $(n=10)$; apart from its smooth apical part, it is sculptured with regularly spaced, very fine, incised, axial lines, $24(\mathrm{n}=1)$ per $0.2 \mathrm{~mm}$ on protoconch whorl $2 \frac{1}{4}-23 / 4$. In almost all shells the protoconch is very badly damaged, with missing whorls, or at least very strongly eroded. Protoconchs still showing some axial lines are rare ( 1 out of 44 ). The teleoconch (fig. 131) has up to $8 \frac{1}{4}$ whorls, separated by an indented suture; it is sculptured with mostly regularly placed, discontinuous, orthocline, lamellar, not or slightly 


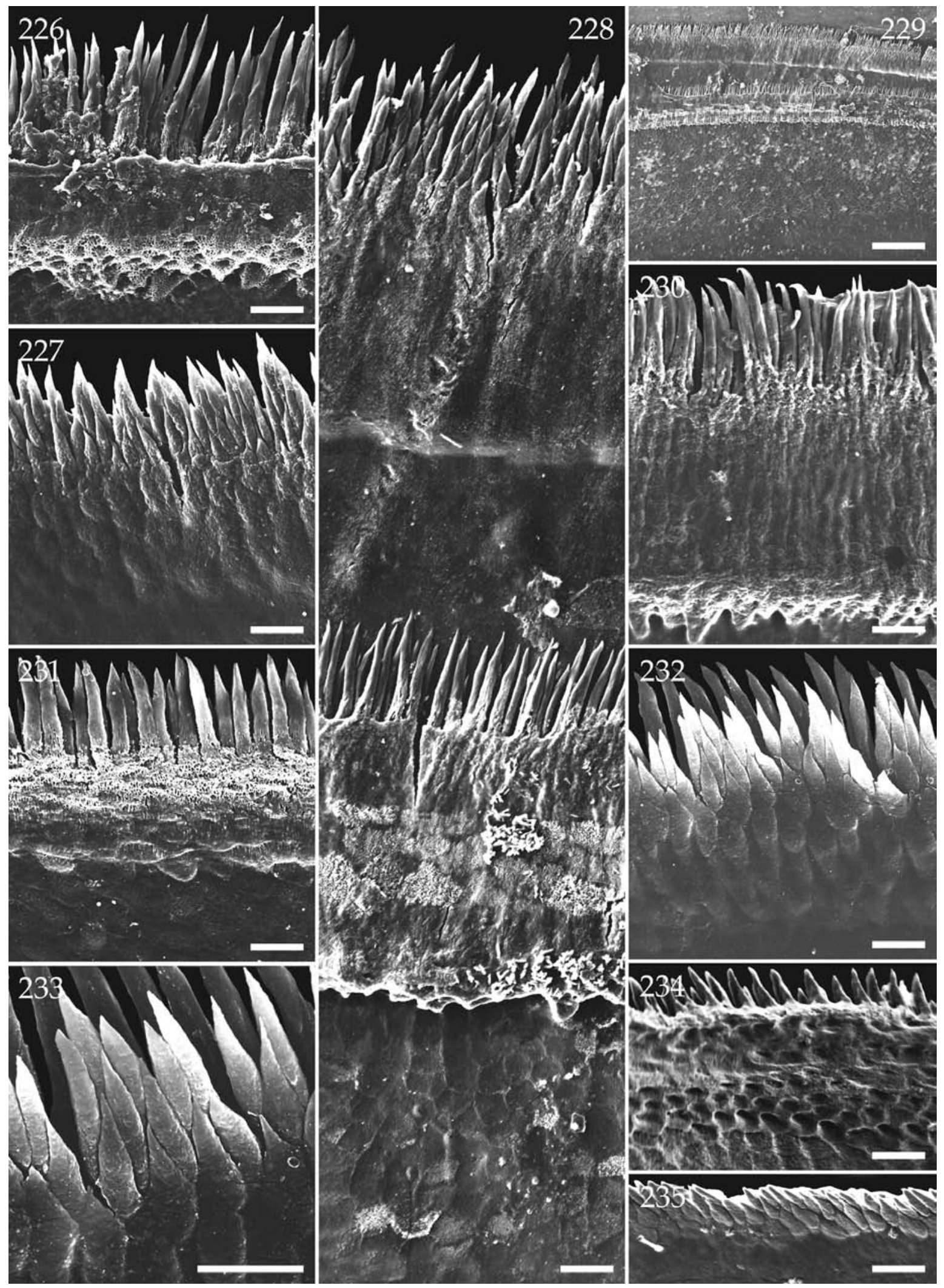


curved, very low costae, not or hardly touching the adjoining whorls. The number of costae on the $2^{\text {nd }}$, $3^{\text {rd }}, 5^{\text {th }}$ and younger teleoconch whorls usually increases quickly, exceeding 80 costae on the $7^{\text {th }}$ whorl and $>100$ on the $8^{\text {th }}$ whorl. There are up to 130 costae on a whorl; on the $8^{\text {th }}$ whorl in a shell of $20.8 \mathrm{~mm}$ in height. The teleoconch is additionally sculptured with numerous, inconspicuous, spiral threads, which are usually obsolete on the initial whorls. Aperture with about equally long parietal, palatal, basal and columellar sides, which are gradually changing into one another. There is a narrow umbilicus.

Operculum (fig. 150). Operculum paucispiral, with interconnected coils as in Surrepifungium patamakanthini spec. nov. (fig. 3). At the outside of the operculum (fig. 150) there are 24 wavy, segmented threads per $0.1 \mathrm{~mm}(\mathrm{n}=1)$, running about perpendicular to the growth lines.

Radula and Jaw. Unknown.

Spawn (figs 296-297). Egg-capsules (fig. 296) ovoid, somewhat transparent, smooth or with small protuberances, not embedded with sand, 1.31-2.88 mm (mean $=1.98, \mathrm{n}=10)$ in diameter, e.g. measured horizontally, from left to right in figure 296, containing 480-820 eggs (mean $=618.2, \mathrm{n}=10$ ) each. The mucus threads that connect the egg-capsules are straight and not sculptured as in Epifungium pseudotwilae spec. nov. (fig. 295) or with a distinct pattern of engraved, diagonal lines (fig. 297).

Habitat. The snails and their egg-capsules were found at 5-38 m, associated with Ctenactis crassa (Dana, 1846), C. echinata (Pallas, 1766) and Herpolitha limax (Esper, 1797). They usually live attached to the underside of these mushroom corals with their mucus threads. The host corals were found on a coral slope or on a sandy bottom bordering a coral slope.

Figs 226-235. Jaw details. 226-227, Surrepifungium costulatum, radula in Fig. 163; 228-230, S. ingridae; 228-229, Sulawesi, Indonesia; 230, Palau; 231-233, S. patamakanthini, radula in Fig. 167; 234-235, S. oliverioi, radula in Fig. 165. 226, 230-231, 234, jaw, outer surface; 227, 232-233, 235, jaw, inner surface; 228-229, outer surface jaw on top of inner surface second jaw; Scale bars $=0.01 \mathrm{~mm}$. SEM Photos.
Differentiation. Conchologically this species strongly resembles Epifungium pseudotwilae spec. nov. See the differentiation of that species.

Remarks. See the remarks on Epifungium pseudotwilae spec. nov.

\section{Epifungium ulu (Pilsbry, 1921)}

Epitonium ulu Pilsbry, 1921: 376, fig. 11c; Bosch, 1965: 267, fig. 1; Robertson, 1970: 45; Hatfield, 1976: 135, table 1; Taylor, 1977: 253, 258, fig. 7; Kay, 1979: fig. 53a, b; Loch, 1982: 3, 1 fig.; Bell, 1985: 159, figs 1-6; Dushane 1988a: 31, figs 3, 4; 1988b: 9, 1 fig.; Wilson, 1993: 273; A. Gittenberger et al., 2000: 11-12, figs 11-12, 17, 21, 29, 44.

Material. USA. Hawaii (hosted by Fungia (Lobactis) scutaria): holotype ANSP 127818. Additionally studied material: 9 specimens, 1 clutch of egg-capsules. EGYPT. Red Sea, 300-350 km S of Hurghada (hosted by Ctenactis echinata, Fungia (Danafungia) horrida, F. (Fungia) fungites and $F$. (Verrillofungia) repanda), 39 specimens, 3 clutches of egg-capsules, 3 r, 5 d. SEYCHELLES. W St. Francois atoll (fungiid host unknown), 1 specimen. MALDIVES. Ari Atoll, Off Vilamendhoo Island (hosted by $F$. $(V$.) concinna and $F$. $(V$.) repanda), 14 specimens, 2 d. THAILAND. Krabi, Phiphi Islands (hosted by $F$. $(V$.) concinna and $F$. (V.) repanda), 4 specimens, 1 clutch of egg-capsules, 3 d. PHILIPPINES. Cebu (hosted by $F$. ( V.) repanda), 1 specimen. INDONESIA. NE Kalimantan, Berau Islands (hosted by $F$. (D.) scruposa), 3 specimens, 1 clutch of egg-capsules. N Sulawesi (hosted by $F$. $(V$.) repanda), 1 specimen. SW Sulawesi, Spermonde archipelago (hosted by $F$. (D.) horrida, F. (D.) scruposa, F. (F.) fungites, $F$. $(L$.$) scutaria, F$. $(V$.) concinna, $F$. $(V$.) repanda, $F$. $(V$.) spinifer, Halomitra pileus, Herpolitha limax and Sandalolitha robusta), 247 specimens, 91 clutches of egg-capsules, $11 \mathrm{~d}$. Moluccas, Ambon (hosted by $F$. (F.) fungites and $F$. (V.) repanda), 2 specimens, $1 \mathrm{~d}$. Bali (hosted by C. echinata, $F$. (D.) horrida, $F$. (F.) fungites and $F$. $(V$.) repanda), 28 specimens, 6 clutches of egg-capsules, $2 \mathrm{~d}$. PALAU. Off Koror (hosted by C. echinata, $F$. (D.) horrida, F. (F.) fungites, $F$. $(V$.) concinna, $F$. $(V$.$) repanda, H$. pileus and $S$. robusta), 40 specimens, 12 clutches of egg-capsules.

Type locality. USA. Hawaii.

Shell (figs 70-73, 111, 129; table 1). Shell fragile, with convex whorls, creamy white. The shell height/ width indexes (table 1) vary considerably, from 1.7 to $3.3(\mathrm{n}=26)$, resulting in shells varying from moderately broad-conical (fig. 71) to slender-conical (figs 70, 72-73). For dimensions and number of costal and spiral ribs on the $2^{\text {nd }}$ and the $5^{\text {th }}$ teleoconch whorls, see table 1. Most specimens that were found are about $4 \mathrm{~mm}$ in height (e.g. fig. 73). Most adult 


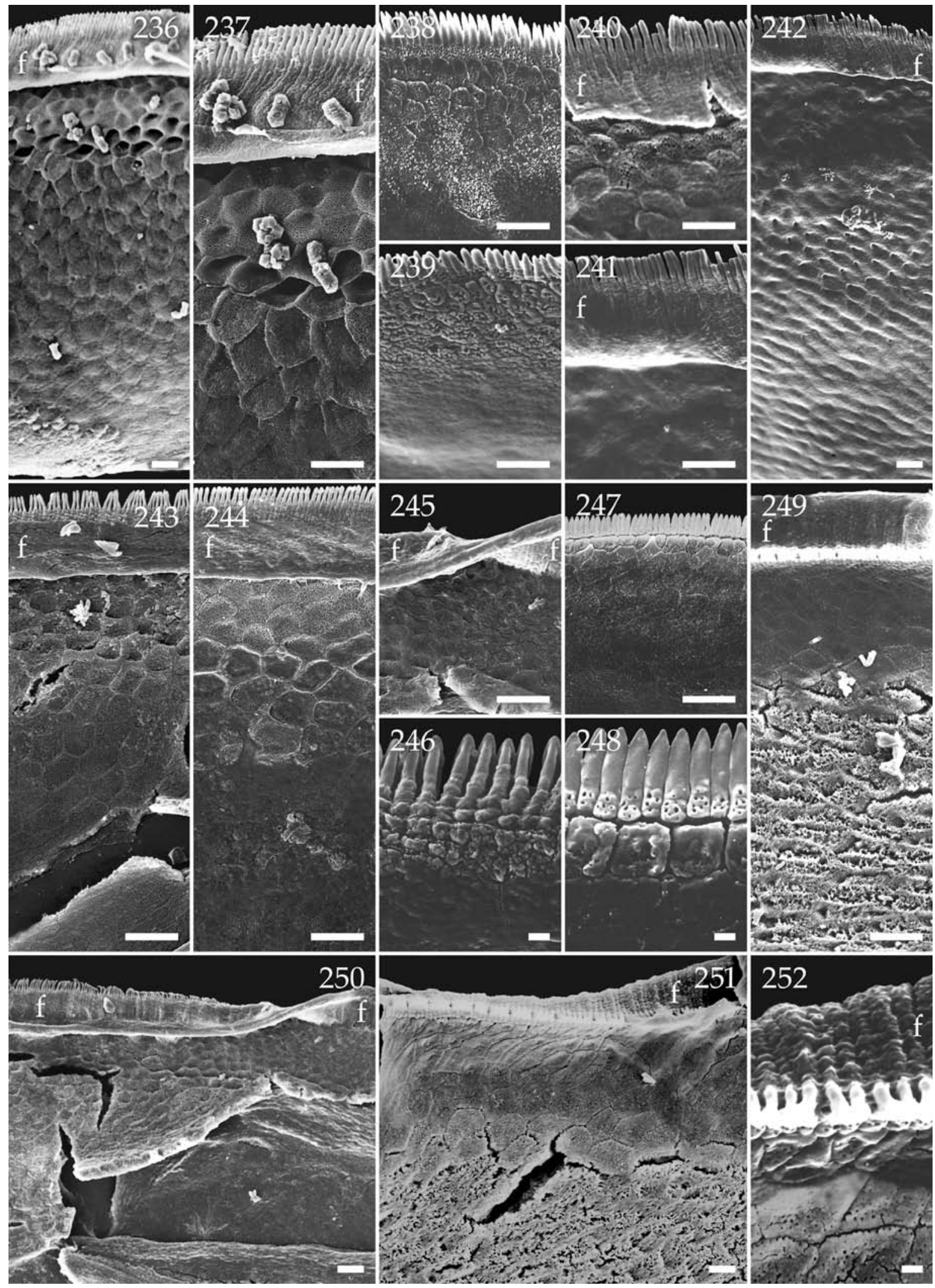


(with egg-capsules) specimens that were found are $8-12 \mathrm{~mm}$ in shell height, with about $15 \mathrm{~mm}$ for the largest shells. However, an exceptionally large specimen (fig. 70), collected off Bali, Indonesia, reaches $28.2 \mathrm{~mm}$ in height. The holotype, missing the protoconch and the initial teleoconch whorl or whorls, measures $14.2 \times 5.7 \mathrm{~mm}$. The protoconch (fig. 111) has 31/4-31/2 whorls $(n=10)$; apart from its smooth apical part, it is sculptured with regularly spaced, very fine, incised, axial lines, $25(\mathrm{n}=1)$ per $0.2 \mathrm{~mm}$ on protoconch whorl $2 \frac{1}{4}-23 / 4$. The teleoconch (fig. 129) has up to $123 / 4$ whorls, separated by a moderately deep suture; it is sculptured with mostly regularly placed, usually discontinuous, orthocline, lamellar, low costae, touching the adjoining whorls. From about the $5^{\text {th }}$ teleoconch whorl onwards, the costae usually become slightly coronate just before reaching the preceding whorl; they curve adaperturally while touching it. In most specimens the number of costae remains approximately the same on all whorls, with adjoining whorls differing in about two costae at most. One shell with a height $21.6 \mathrm{~mm}$, has $21,21,21$ and 22 costae on the $2^{\text {nd }}, 3^{\text {rd }}, 5^{\text {th }}$ and $11^{\text {th }}$ teleoconch whorl, respectively; on the $12^{\text {th }}$ teleoconch whorl however, there are 39 costae, the highest number recorded for Epifungium ulu. Very fine, irregularly placed, incised, axial lines are present from about the $6^{\text {th }}$ teleoconch whorl onwards. The teleoconch is additionally sculptured with very low, inconspicuous, spiral threads, which are randomly placed on the whorls and are usually obsolete on the initial whorls. Although the number of spiral threads on the $2^{\text {nd }}, 3^{\text {rd }}$, and $5^{\text {th }}$ teleoconch whorls remains approximately the same (adjoining whorls differing in about two), this number usually increases slowly towards the younger whorls, sometimes becoming numerous from about the $9^{\text {th }}$ teleoconch whorl onwards. Aperture subcircular. About half of the specimens (14 out of 25) have a closed umbilicus; in the remaining 11 shells the umbilicus is very narrow, visible in oblique view only. The presence of either

Figs 236-252. Jaw details. 236-238, Epidendrium aureum spec. nov., radula in Fig. 160; 239-242, E. sordidum spec. nov., Philippines; 243-252, Epifungium ulu; 243, 245, 249-252, shell height = $14.0 \mathrm{~mm}$, radula in Fig. $174 ; 244,246-248$, shell height $=28.2 \mathrm{~mm}$, shell in Fig. 70. 236-237, 240-246, 250, jaw, outer surface; 238-239, 247-249, 251-252, jaw, inner surface. 245, 249-252, illustrating upturned jaw flap (f). Scale bars $=0.01 \mathrm{~mm}$. SEM Photos. a closed or an open umbilicus is not correlated with shell size.

Operculum (fig. 151). Operculum paucispiral, with interconnected coils as in Surrepifungium patamakanthini spec. nov. (fig. 3). At the outside of the operculum (fig. 151) there are 27 wavy, segmented threads per $0.1 \mathrm{~mm}(\mathrm{n}=1)$, running about perpendicular to the growth lines.

Radula (figs 174, 194, 214; table 2). The radulae of four Indonesian snails with shell heights of 9.1, 10.0, 14.0 and $28.2 \mathrm{~mm}$, respectively, were studied (figs 174, 194; table 2). The radulae of the two largest snails could not be accurately counted (table 2). No distinct differences in form and/or size of the teeth, related to the size of the snails, were found. Each tooth (figs 174, 194, 214) consists of a moderately slender stem and a somewhat broader blade, which merge gradually; the blade has 2-5 acute, secondary cusps. The teeth (figs 174) are attached to the radular plate along the bases, which takes $1 / 2$ to $3 / 4$ of the length of a tooth (figs 194, 214). The number of secondary cusps (table 2) gradually increases from 2 on the innermost tooth (fig. 194, left) to 4-5 in between the $4^{\text {th }}-14^{\text {th }}$ tooth, after which the number decreases to 2-3 on the ultimate, i.e. $15^{\text {th }}$ tooth (fig. 214 , right). The apical cusp and the secondary cusp directly underneath it are usually similar in size and somewhat curved towards each other; all other secondary cusps are usually similar in size and somewhat curved upwards, away from the stem (figs 174, 194). Starting from the innermost, smallest tooth, with a height of $0.028-0.029 \mathrm{~mm}(\mathrm{n}=2)$, the teeth gradually increase in size to almost two times that height, i.e. 0.049$0.050 \mathrm{~mm}(\mathrm{n}=2)$, up to the $7^{\text {th }}-8^{\text {th }}$ tooth, after which they gradually become smaller until the penultimate, i.e. $14^{\text {th }}, 0.038-0.039 \mathrm{~mm}(\mathrm{n}=2)$ high tooth, which is followed by the somewhat smaller, usually malformed, ultimate tooth, with a height of $0.028 \mathrm{~mm}$ (n =2) (table 2).

Jaw (figs 21, 24, 31-32, 243-252, 259-260; table 2). Three jaws from three specimens from Indonesia were studied (table 2). The denticulate edge consists of a row of slender, blunt denticles (figs 31, 246, 243-244, 259), which are basally pitted on the inside (figs 32, 248, 260). They have a maximum size of $0.0038-0.0042 \mathrm{~mm}(\mathrm{n}=2)$. Seen from the outside 


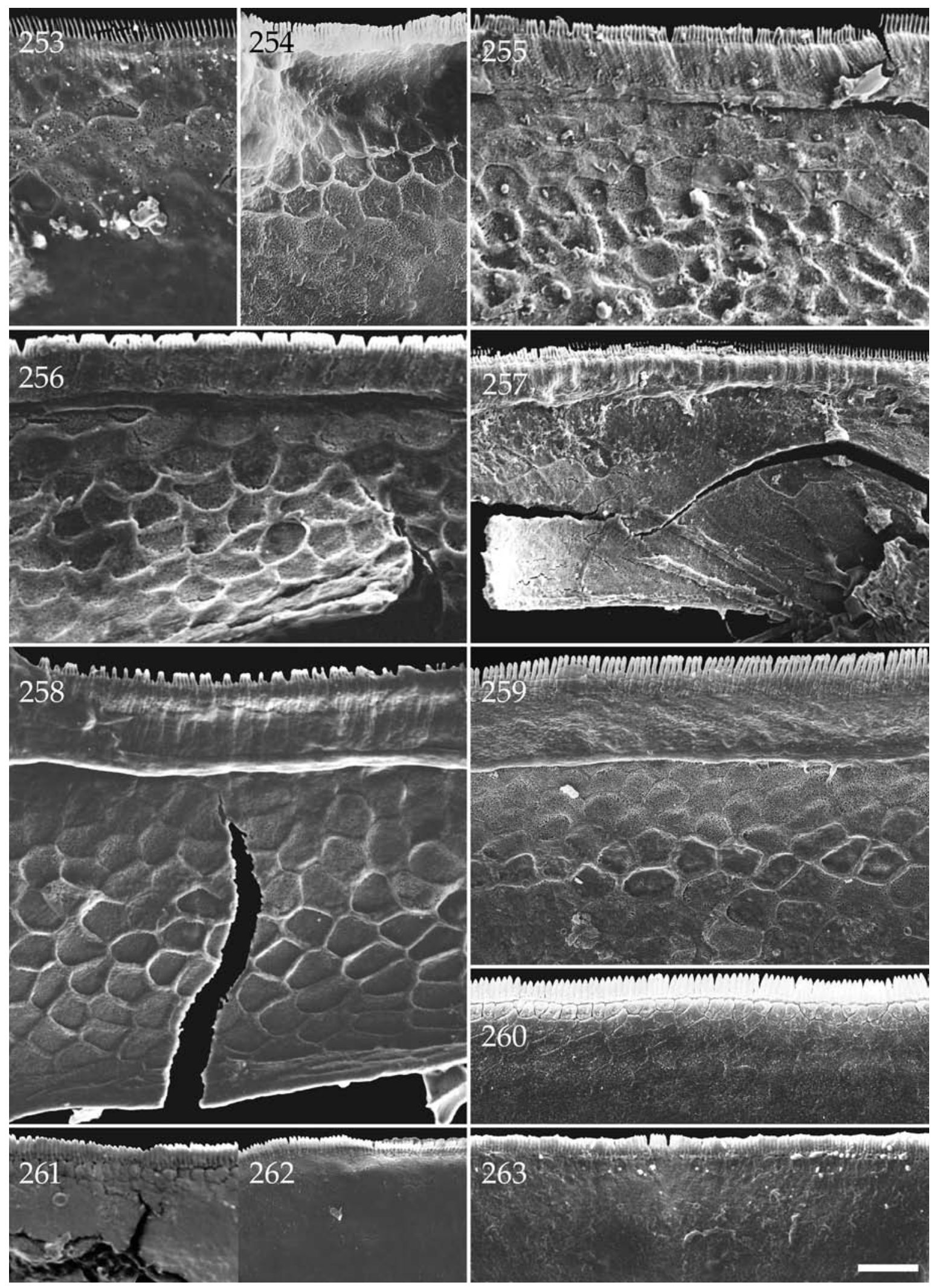


(figs 243-244, 259), 50-65 denticles ( mean $=57.7$, n =3) per $0.05 \mathrm{~mm}$ extend above a $0.0038-0.0042 \mathrm{~mm}$ $(\mathrm{n}=2)$ broad, granulated jaw-flap (figs 243-244), which lies loosely over part of the jaw-pattern. That the jaw-flap lies loose, is distinct when it turns over, becoming visible from the inside of the jaw (figs 249, 252-252) and revealing the jaw-pattern that is usually beneath it, from an outside view of the jaw (figs $245,250)$. The pattern, as far as visible under a jawflap that has not turned over (figs 243-244, 259), consists of rows of sunken, pentagonal figures (fig. 21); the upper two or three rows are densely pitted, followed further on by one or two rows that are not pitted and after that by rows, which are scarcely pitted and gradually become obsolete away from the denticulate jaw-edge. On the inner surface of the jaw, just below the denticles, there is a row of engraved, scarcely pitted, irregularly square-like figures (fig. 248), followed further on by several rows of densely pitted, engraved, irregular figures (figs 24, 251-252, 260 ), gradually becoming obsolete away from the denticulate edge, sometimes changing in a rough surface with relatively large holes (figs 249, 251).

Spawn (298-299). Egg-capsules (fig. 299) ovoid, without distinct protuberances, sometimes embedded with sand, $1.00-1.60 \mathrm{~mm}($ mean $=1.27, \mathrm{n}=20)$ in diameter, e.g. measured horizontally, from left to right in figure 298, containing 120-330 eggs (mean = $193.9, \mathrm{n}=20$ ) each. The mucus threads that connect the egg-capsules are strongly twisted and not sculptured (fig. 299).

Habitat. The snails and their egg-capsules were found at 1-35 m, associated with Ctenactis echinata (Pallas, 1766), Fungia (Danafungia) horrida Dana, 1846, F. (D.) scruposa Kluzinger, 1879, F. (Fungia) fungites (Linnaeus, 1758), F. (Lobactis) scutaria Lamarck, 1801, Fungia (Verrillofungia) concinna Verrill, 1864, $F$. $(V$.) repanda Dana, $1846, F$. $(V$.) spinifer Claereboudt and Hoeksema, 1987, Halomitra pileus (Linnaeus,

Figs 253-263. Jaw details. 253, Epifungium adgravis, radula in Fig. 15; 254, E. hartogi, radula in Fig. 169; 255-256, 261, E. hoeksemai; 256, 261, radula in Fig. 170, shell height $=14.5 \mathrm{~mm}$, Sulawesi, Indonesia; 255, shell height $=11.9 \mathrm{~mm}$, Palau; 257, 262, E. lochi, radula in Fig. 171; 258, 263, E. nielsi, radula in Fig. 172; 259-260, E. ulu, shell in Fig. 70. 253-259, jaw, outer surface; 260-263, jaw, inner surface. Scale bar $=0.01 \mathrm{~mm}$. SEM Photos.
1758), Herpolitha limax (Esper, 1797), Sandalolitha robusta (Quelch, 1886). They usually live attached with their mucus threads to the underside of these mushroom corals or to hard substrata underneath. Most host corals were found on coral slopes. Taylor (1977: 253) notes that snails of E. ulu, in an aquarium, can also feed on the sea-anemone Aiptasia spec.

Distribution (fig. 87). The snails and their egg-capsules were found in the Indo-West Pacific, from Egypt (Red Sea), Seychelles, Maldives, Thailand, Philippines, Indonesia and Palau to Australia.

Differentiation. The shells resemble those of Epifungium adgranulosa spec. nov., E. adgravis spec. nov., E. adscabra spec. nov., E. hoeksemai, E. marki spec. nov. and $E$. nielsi spec. nov. They differ in having a relatively low number of costal ribs and spiral threads on the $2^{\text {nd }}, 3^{\text {rd }}$ and $5^{\text {th }}$ teleoconch whorl (table 2 ), the lowest average T3 value, i.e. $0.69 \mathrm{~mm}$ (table 2), and in being associated with other host species (see the habitat descriptions), with the exception of Fungia (Fungia) fungites, which is associated with both $E$. $u l u$ and $E$. hoeksemai. See the differentiation of $E$. hoeksemai.

Remarks. According to Hoeksema (pers. comm.), off Hawaii, the type locality of Epifungium ulu, the only common mushroom coral species is Fungia (Lobactis) scutaria. The only epitoniid species that is associated with this host species is E. ulu. Therefore, specimens described as E. ulu from Hawaii are most probably correctly identified. At other Indo-Pacific localities the host species of E. adgranulosa spec. nov., E. adgravis spec. nov., E. adscabra spec. nov., E. hoeksemai, E. marki spec. nov. or E. nielsi spec. nov. may also be present (see the habitat descriptions of those species). Therefore all the references in the literature to "Epitonium ulu" Pilsbry, 1921, from other localities than Hawaii, should be treated with great care, because other species might be involved. The description of "Epitonium ulu" in A. Gittenberger et al. (2000: 11-12, figs 17, 21) is at least partly based on E. adgranulosa spec. nov., E. adgravis spec. nov., E. adscabra spec. nov., and E. nielsi spec. nov., but the two figures do show E. ulu indeed. The epitoniids collected off North Queensland with Fungia spp. and Heliofungia actiniformis, and identified as E. ulu by Loch (1982), probably belong to 


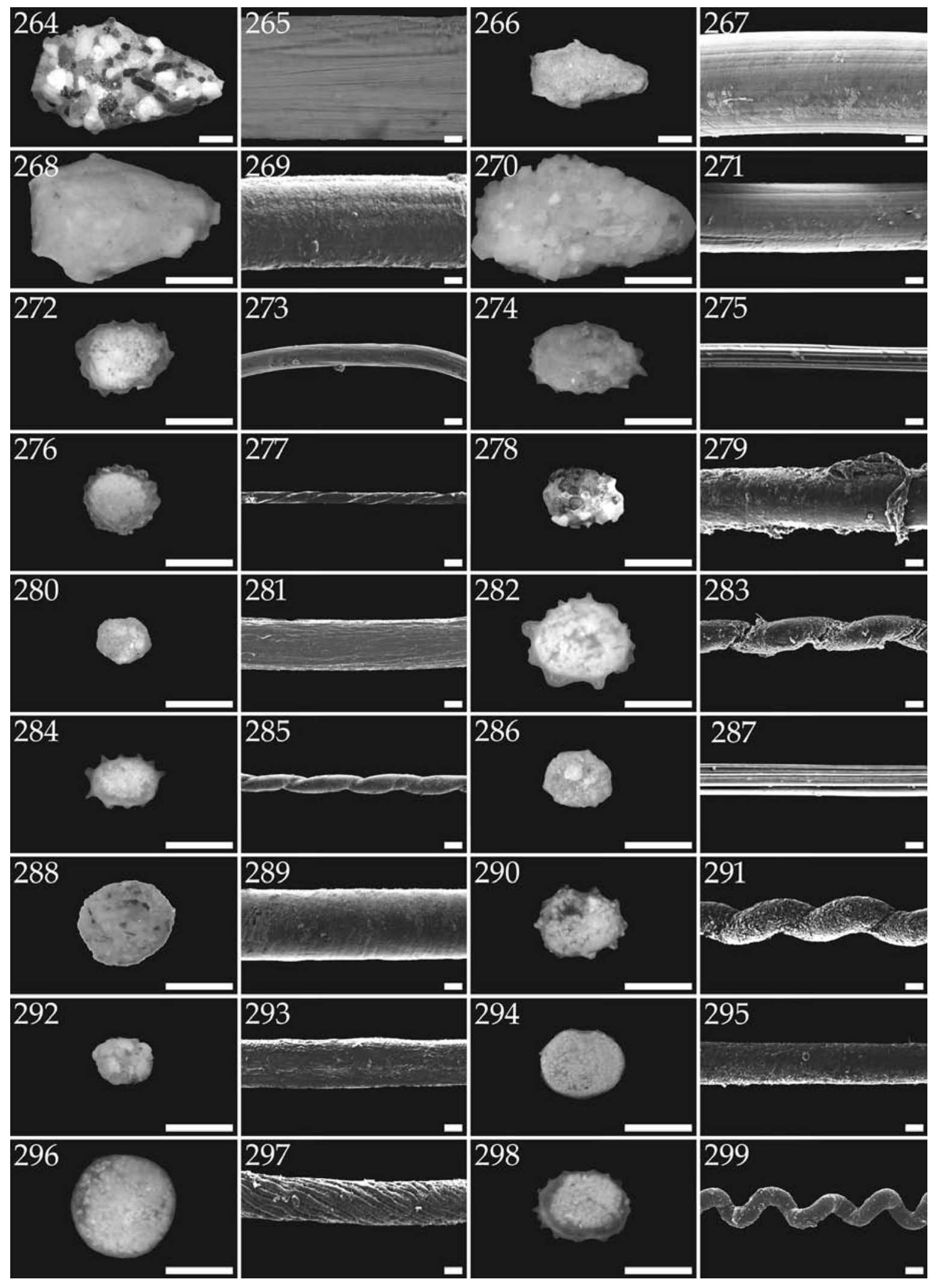


a variety of species. Those found associated with the fungiid Heliofungia actiniformis, may be E. hoeksemai. The shell figured by Loch (1982: 3, on the right) is here considered to represent E. ulu. The Fungia host species of the epitoniids E. adgranulosa spec. nov., E. adgravis spec. nov., E. adscabra spec. nov. and $E$. nielsi spec. nov., are all known from off North Queensland (Hoeksema, 1989). Because these four epitoniid species closely resemble E. ulu in shell shape and sculpture, they may be partly represented in the material recorded by Loch (1982). The two shells of " $E$. ulu" figured by Dushane (1988a: 31, figs $3,4)$ from the Red Sea, off Tiran Island, Straits of Tiran, and off Sinafir Island, Saudi Arabia, resemble E. ulu and E. adgranulosa spec. nov.

\section{General discussion}

Even though Bouchet and Waren (1986: 469) argue that the low amount of variation within epitoniids in general may reflect a low degree of specialization, many coral-associated, conchologically poorly differentiated epitoniids have specialized on only one or a restricted number of host species, and have large ranges, similar to those of their hosts. This adaptive radiation of coral-associated epitoniids was not noticed before because most species cannot easily or not at all be identified unequivocally on the basis of conchological characters alone. Their identities as separate gene pools are convincingly demonstrated by molecular data, however. Shell shapes and sculpture are only partially diagnostic because of interspecifically overlapping character states. In most cases, the operculum, the jaw, the radula, the spawn and/or the habitat do tell more about the identity of the species involved. These characters can also be very valuable for distinguish-

Figs 264-299. Egg-capsules and mucus threads. 264-265, Surrepifungium costulatum; 266-267, S. ingridae; 268-269, S. patamakanthini; 270-271, S. oliverioi; 272-273, Epidendrium aureum; 274275, E. sordidum; 276-277, Epifungium adgranulosa; 278-279, E. adgravis; 280-281, E. adscabra; 282-283, E. hartogi; 284-285, E. hoeksemai; 286-287, E. lochi; 288-289, E. marki; 290-291, E. nielsi; 292-293, E. pseudolochi; 294-295, E. pseudotwilae; 296297, E. twilae; 298-299, E. ulu. Scale bars: even numbers $=1 \mathrm{~mm}$; odd numbers $=0.01 \mathrm{~mm}$. Photos: through binoc. (even numbers $\& 265$ ) and with SEM (odd numbers except for 265). ing between at least the newly described genera.

Many (sub)generic names of Epitoniidae are available (see e.g. Kilburn, 1985; Wenz, 1940). Still we found it necessary to introduce three more genus level taxa, viz. Epidendrium gen. nov., Epifungium gen. nov. and Surrepifungium gen. nov. The DNAdata indicate that these three new genera are monophyletic and most closely related to each other, indicating that a host-shift from sea-anemones to corals or vice versa has occurred only once in their evolutionary history (A. Gittenberger et al., in prep.). These new taxa are given a generic instead of a subgeneric status, because molecular data indicate that the genetic distance between the two Epitonium species $E$. clathrus and E. clathratulum versus the Cycloscala species C. crenulata (Pease, 1867) is smaller than the genetic distance between the three new coral-associated genera. Another reason to introduce three genera instead of a single new genus with three subgenera, is that no morphological character is known to unequivocally distinguish the combined three taxa from other epitoniid genera. The only non-molecular character known, is the association with hard corals instead of sea anemones and zoanthids.

It was repeatedly argued in literature (e.g. Richter and Luque, 2004) that 'Epitonium' billeeanum and 'E.' dendrophylliae should not be placed in Epitonium because these species distinctly differ from the type species Epitonium scalare (Linnaeus, 1758). This suggestion was not followed however, because of a lack of data, e.g. molecular data, and the uncertainties in epitoniid classification in general. Another reason why these three generic taxa have not been recognized before is that 16 of the 20 species involved were unknown prior to 2000 (A. Gittenberger et al., 2000; Bonfitto and Sabelli, 2001; A. Gittenberger, 2003). A final argument in favour of introducing new genera is that most type species of epitoniid genera in the literature, are either distinctly different in morphology and/or clearly not associated with coral species, because no corals are present within their ranges and/or their hosts are known to be sea-anemones. No epitoniid species is known to be associated with both corals and sea-anemones. Dushane (1988a), Yamashiro (1990) and Mienis (1994) indicated that Epitonium bullatum may be related to both cnidarian taxa, but A. Gittenberger et al. (2000) have demonstrated that here the coral-associated epitoniids are in fact Epifungium twilae. 
Species that are sympatric from a geographical perspective are usually found with different host coral species; whenever they share a host species they are not entirely syntopic, occurring at different positions on or below the host coral.

Most (sub)genera in the family Epitoniidae have been introduced and described on the basis of teleoconch shell characters only, with a special focus on shell shape, the costal and spiral sculpture, the umbilicus and the suture (see e.g. Weil et al., 1999; Nakayama, 2003). Convergent or parallel evolution in these characters may be common among epitoniids in general (Kilburn, 1985: 241) and has certainly played an important role in the origin of the 22 species that are described here.

Shell shapes often vary between very broad and relatively slender conical within species and within genera, as for example in Epidendrium (figs 51-55) and Epifungium (figs 61-76, 88-91). Within Surrepifungium, the shells of $S$. ingridae and S. patamakanthini spec. nov. have coronate costal ribs (figs 38, 40), while the ribs in $S$. costulatum and S. oliverioi are more regularly curved (figs 33-37). A spiral sculpture may be present on the entire teleoconch in some species, as in e.g. Surrepifungium ingridae (fig. 113 ) and Epitonium celesti (in Bouchet and Waren, 1986: 509), while it is obsolete or absent in closely related species, i.e. Surrepifungium patamakanthini spec. nov. and Epitonium graviarmatum spec. nov. (fig. 117). The number of ribs is variable within many epitoniid species and can even differ strongly between the whorls of a single shell (table 1; Robertson, 1983b: 116). Within species, shells with and without an open umbilicus are present, i.e. in Epifungium adgranulosa spec. nov., E. adgravis spec. nov., E. adscabra spec. nov., E. marki spec. nov., E. nielsi spec. nov. and E. ulu. In Epifungium the suture is very deep to almost fenestrate in $E$. marki spec. nov. and E. pseudolochi spec. nov., while it is shallow to somewhat indented in E. adgranulosa spec. nov., $E$. pseudotwilae spec. nov. and E. twilae.

Because teleoconch characters, like the ones referred to above, are still commonly used to characterize or identify epitoniid genera or subgenera within a very speciose genus Epitonium, (e.g. Weil et al., 1999: Appendix II; Bonfitto and Sabelli, 2001; Nakayama, 2003), "epitoniid taxonomy remains in a chaotic state, particularly above the species level" (Kilburn, 1985: 240) and the classification of the genus Epitonium is "very tentative and is aimed solely at grouping together similar species for convenience sake" (Kilburn, 1985: 280).

While comparing molecular, conchological, anatomical, ecological and geographical data of the species described here we found that several characters, which are rarely used in the literature, are more robust for making classifications in the Epitoniidae than are most conchological characters. Kilburn (1985: 241) indicated that the protoconch morphology can be used. We found that the protoconchs of almost all species that are associated with corals consist of $2 \frac{1}{2}-3 \frac{1}{2}$ whorls, with a sculpture of fine, axial lines; this can only be used to recognize the combined three genera that are described here. However, in Epitonium graviarmatum spec. nov., which may also be hosted by corals, there is a different protoconch, consisting of five whorls and a sculpture of costal and spiral lines. No teleoconch characters were found which enable an unequivocal recognition or a differentiation between the genera Epidendrium gen. nov., Epifungium gen. nov. and Surrepifungium gen. nov. The micro-sculpture on the operculum may turn out to be diagnostic, since in the species that are described here it consists of different numbers of wavy threads, running c. perpendicular to the growth lines, i.e. 9 to 20 in Surrepifungium (figs 136-139), versus 20 to 40 in Epifungium (figs 140-151), and none in Epidendrium (figs 132-134). However, Epitonium pyramidalis also has no operculum sculpture (fig. 135). Bouchet and Waren (1986: 472) noted that the opercula of several species of Opalia and Cirsotrema are "minutely beaded" (Bouchet and Waren, 1986: 474, fig. 1116) and "smooth" in Acirsa, Acrilloscala, Cyclindriscala, Eccliseogyra, Epitonium, Gregorioiscala, Iphitus and Periapta (Bouchet and Waren, 1986: 473-474, figs 1106-1115, 1117-1118).

The radular morphology is at least partly diagnostic for Epifungium, since in that genus the snails have teeth without a clear basal denticle and with one to six secondary cusps (figs 169-174). The radula cannot be used to identify Epidendrium, Surrepifungium and most other epitoniid genera. The alleged, sexrelated, ontogenetic changes in the structure of the epitoniid radulae (Page and Willan, 1988) are most probably based on a misidentification of two species that were regarded as a single species (see the remarks on Epidendrium gen. nov.). Many wentletraps have teeth with a distinct basal denticle, an acute apical 
cusp (fig. 13) and occasionally an inconspicuous, secondary cusp. These teeth are typical for some Epidendrium and Surrepifungium species (figs 160161, 163-167), but also for Acirsa subdecussata (in Bouchet and Waren, 1986: 470, fig. 1098), Cirsotrema varicosa (figs 152, 195), Epidendrium aureum spec. nov. (figs 160-161, 183, 203), Epitonium celesti (in Bouchet and Waren, 1986: 470, fig. 1099), E. clathrus (fig. 156), E. pyramidalis (figs 157, 180, 200) and even Janthina janthina (fig. 16), a species of still unclear affinities, classified with the Janthinidae, Janthinoidea Lamarck, 1810 [= Epitoniacea Berry, 1910].

The characters of the jaws seem to be much more useful to identify the genera of the species that are studied here. More specifically the shapes of the denticles at the denticulate edge, the structure of the jaw-flap and the pattern on both the inner and the outer surface of the jaw, are informative regarding the coral-associated species studied. The structure of the jaw may prove to be useful for other epitoniid genera as well. For example, Epitonium ancillottoi and $E$. spec. 1 have distinctly different radular teeth (figs 153-154, 176-177, 196-197) but similar jaws (figs 219-222), which may be considered indicative of being closely related, as is also indicated in this case by molecular and conchological data. In both Cirsotrema varicosa and Gyroscala lamellosa the jaws have multiple rows of slender, blunt denticles, without a jaw-flap, and with a pattern of raised and sunken arch-like figures (figs 17-19, 215-217). They differ distinctly from the jaws known from $E$. $p y$ ramidalis, E. ancillottoi, E. spec. 1 and E. clathratulum (figs 218-225). In Gyroscala the shells more closely resemble Epitonium (see e.g. Dushane, 1987b: 12) than Cirsotrema species, differing in having a basal cord, which is missing in Epitonium and present in Cirsotrema. Kilburn (1985: 241), who treats Gyroscala as a genus (as do we), noted that Thiele (1929) and Fretter and Graham (1982) classified Gyroscala as a subgenus of Cirsotrema, whereas Americans (e.g. Abbott, 1974) considered Gyroscala a subgenus of Epitonium. The presence versus absence of a basal cord is the most frequently used shell character in epitoniid taxonomy (Kilburn, 1985: 241). Both jaw morphology and molecular data (A. Gittenberger et al., in prep.) indicate that Gyroscala is more closely related to Cirsotrema than to Epitonium, which is in conformity with the view that the presence of a basal cord is a more informative character state than most other teleoconch characters.

Also in Nudibranchia there may be two jaws flanking the radula. Surprisingly, some of these jaws (e.g. Rudman and Avern, 1989; Smith and Gosliner, 2003), which are often described in literature, may closely resemble those of epitoniids, in having a denticulate edge with several rows of blunt denticles as in figure 217. No pattern seems to be present on the inner surface of nudibranch jaws and it is unclear whether the outer surface is sculptured. In a preliminary literature study, we only found jaws figured from the inside.

Most epitoniids have ovoid to roundish egg-capsules. Therefore, the irregular, pentagonal egg-capsules that are known from Surrepifungium can be used to distinguish these species from conchologically similar species in other genera, like for example Epitonium ancilottoi and E. spec. 1, which have roundish egg-capsules.

It has to be concluded that most monophyletic groups of Epitoniidae associated with coral species cannot unequivocally be identified on the basis of teleoconch characters only, because of a large amount of convergence or parallel evolution. A combination of molecular data, morphological data of the protoconch, the operculum, the jaws and the spawn, is necessary identifying the clades present. Unfortunately such data sets are not yet available for most epitoniid taxa. A more detailed discussion on the evolutionary history of the epitoniid species, especially those occurring associated with coral species, will be given in an article presenting a phylogeny reconstruction based on the DNA marker CO-I (A. and E. Gittenberger, in prep.).

\section{Acknowledgements}

We are grateful to Merijn Bos, Pat Colin, Rachel Colin, Hans Ditlev, Mark Erdmann, Jeroen Goud, Victor de Grund, Bert W. Hoeksema, Bas Kokhoorn, Alfian Noor, Somnuk Patamakanthin, Somwang Patamakanthin, Carlos A. Sánchez, Niels Schrieken, Frank Swinnen and Nicole de Voogd for their help in providing information and material used in this study. In particular we thank Dr David G. Reid (London) for the many constructive comments which enabled us to improve the manuscript. The research 
in Indonesia was sponsored by the Indonesian Institute of Sciences (LIPI). This research project was supported by WOTRO (grant nr. W 82-249) with additional funding by KNAW, the Alida Buitendijkfonds, and the Jan Joost ter Pelkwijkfonds.

\section{References}

Abbott RT. 1974. American seashells. Second edition, 663 pp. Van Nostrand Reinhold Company: New York.

Bandel K. 1984. The radulae of Caribbean and other Mesogastropoda and Neogastropoda. Zoologische Verhandelingen 214: $1-188$.

Bell JL. 1985. Larval growth and metamorphosis of a prosobranch gastropod associated with a solitary coral. Proceedings of the Fifth International Coral Reef Congress, Tahiti 5: 159-164.

Bonfitto A, Sabelli B. 2001. Epitonium (Asperiscala?) oliverioi, a new species of Epitoniidae (Gastropoda) from Madagascar. Journal of Molluscan Studies 67: 269-274.

Bosch HF. 1965. A gastropod parasite of solitary corals in Hawaii. Pacific Science 19(2): 267-268.

Boss KJ. 1982. Mollusca. In: S.P. Parker (ed.), Synopsis and classification of living organisms. Vol. 1: 945-1116. McGrawHill Book Co.: New York.

Bouchet P, Warén A. 1986. Revision of the Northeast Atlantic bathyal and abyssal Aclididae, Eulimidae, Epitoniidae (Mollusca: Gastropoda). Bollettino Malacologico, Supplemento 2: 299-576.

Debelius H. 1996a. Leichenschänder, Wendeltreppen äffen ihr Opfer nach. Unterwasser, das Tauchmagazin 11: 150-151.

Debelius H. 1996b. Nudibranchs and sea snails. Indo-Pacific field guide. 321 pp. IKAN-Unterwasserarchiv: Frankfurt.

Dushane H. 1987a. Classification of three species of Epitoniidae found in Hawaii waters. Hawaiian Shell News 35(6): 1, 4.

Dushane H. 1987b. The many synonymic names of Gyroscala lamellosa (Lamarck, 1822). Hawaiian Shell News 35(11): 12.

Dushane H. 1988a. Geographical distribution of some Epitoniidae (Mollusca: Gastropoda) associated with fungiid corals. Nautilus 102: 30-35.

Dushane H. 1988b. Hawaiian Epitoniidae (continued). Hawaiian Shell News 36(11): 7, 9 .

Dushane H, Bratcher T. 1965. A new Scalina from the Gulf of California. The Veliger 8(2): 160-161.

Fretter V, Graham A. 1982. The prosobranch mollusks of Britain and Denmark. Part 7. 'Heterogastropoda' (Cerithiopsacea, Triforacea, Epitoniancea, Eulimacea). Journal of Molluscan Studies, Supplement 11: 363-434.

Graham A. 1965. The buccal mass of ianthinid prosobranchs. Proceedings of the Malacological Society of London 36: 323338.

Gittenberger A, Goud J, Gittenberger E. 2000. Epitonium (Gastropoda: Epitoniidae) associated with mushroom corals (Scleractinia: Fungiidae) from Sulawesi, Indonesia, with the description of four new species. Nautilus 114: 1-13.

Gittenberger A. 2003. The wentletrap Epitonium hartogi spec. nov. (Gastropoda: Epitoniidae), associated with bubble coral species, Plerogyra spec. (Scleractinia: Euphyllidae), off Indonesia and Thailand. Zoologische Verhandelingen 345: 139-150.

Hartog JC. den 1987. Observations of the wentletrap Epitonium clathratulum (Kanmacher, 1797) (Prosobranchia, Epitoniidae) and the sea anemone Bunodosoma biscayensis (Fischer, 1874) (Actiniaria, Actiniidae). Basteria 51: 95-108.

Hoeksema BW. 1989. Taxonomy, phylogeny and biogeography of mushroom corals (Scleractinia: Fungiidae). Zoologische Verhandelingen 254: 1-295.

Kay EA. 1979. Hawaiian marine shells. Reef and shore fauna of Hawaii. Section 4: Mollusca. Bernice P. Bishop Museum Special Publication 64(4): i-xviii, 1-653.

Kilburn RN. 1985. The family Epitoniidae (Mollusca: Gastropoda) in southern Africa and Mozambique. Annals of the Natal Museum 27: 239-337.

Loch I. 1982. Queensland epitoniids. Australian Shell News 39: 3-6.

Mienis HK. 1994. Calliactis polypus: a new host of Epitonium bullatum. Epinet 3(2): 5-6.

Nakayama T. 2003. A review of northwest Pacific epitoniids (Gastropoda: Epitoniidae). Monographs of Marine Mollusca 6: $1-143$

Oliverio M, Taviani M, Chemello R. 1997. A coral-associated epitoniid, new to the Red Sea (Prosobranchia, Ptenoglossa). Argonauta 9(10-12): 3-10.

Page AJ, Willan RC. 1988. Ontogenetic Change in the Radula of the Gastropod Epitonium billeeana (Prosobranchia: Epitoniidae). The Veliger 30(3): 222-229.

Perron F. 1978. The habitat and feeding behavior of the wentletrap Epitonium greenlandicum. Malacologia 17(1): 63-72.

Richter A, Luque ÁA. 2004. Epitonium dendrophylliae (Gastropoda: Epitoniidae) feeding on Astroides calycularis (Anthozoa, Scleractinia). Journal of Molluscan Studies 70: 99-101.

Robertson R. 1963. Wenteltraps (Epitoniidae) feeding on sea anemones and corals. Proceedings of the Malacological Society of London 35: 51-63.

Robertson R. 1966. Coelenterate-associated prosobranch gastropods. American Malacological Union Annual Reports 1965: 6-8.

Robertson R. 1970. Review of the predators and parasites of stony corals, with special reference to symbiotic prosobranch gastropods. Pacific Science 24: 43-54.

Robertson R. 1981. Epitonium millecostatum and Coralliophila clathrata: Two prosobranch gastropods symbiotic with IndoPacific Palythoa (Coelenterata: Zoanthidae). Pacific Science 34(1): 1-17.

Robertson R. 1983a. Observations on the life history of the wentletrap Epitonium albidum in the West Indies. American Malacological Union Bulletin 1: 1-12.

Robertson R. 1983b. Axial shell rib counts as systematic characters in Epitonium. Nautilus 97(3): 116-118.

Robertson R, Schutt PL. 1984. Golden Wentletraps on Golden Corals. Hawaiian Shell News 32(11): 1, 4.

Rudman WB, Avern GJ. 1989. The genus Rostanga Bergh, 1879 (Nudibranchia: Dorididae) in the Indo-West Pacific. Zoological Journal of the Linnean Society 96: 281-338. 
Sabelli B, Taviani M. 1984. Red Sea record of a Fungia-associated epitonid. Bollettino Malacologico 20: 91-94.

Schimek RL. 1986. A diet that stings; sea anemones as food for snails. Shells and Sea Life 18(11): 173-175.

Smith VG, Gosliner TM. 2003. A new species of Tritonia from Okinawa (Mollusca: Nudibranchia), and its association with a gorgonian octocoral. Proceedings of the California Academy of Sciences 54(16): 255-278.

Sowerby GB. 1844. Descriptions of new species of Scalaria collected by Hugh Cuming, Esq. Proceedings of the Zoological Society of London 12: 1-38.

Suter J. 1913. Manual of the New Zealand Mollusca. With an atlas of quarto plates. xxiii, $1120 \mathrm{pp}$. John Mackay: Wellington.

Taylor JB. 1977. Growth rates in juvenile carnivorous prosobranchs (Molluska: Gastropoda) of Kaneohe Bay, Oaho, (Hawaii). Proceedings of the Third International Coral Reef Symposium: 253-259.
Thiele J. 1929. Handbuch der systematischen Weichtierkunde. Pt 1.778 pp. Fischer: Jena.

Vestergaard K. Von 1935. Über den Laich und die Larven von Scalaria communis (Lam.), Nassarius pygmaeus (Lam.) und Bela turricola (Mont.). Zoologischer Anzeiger 109: 217-222.

Weil A, Brown L, Neville B. 1999. The Wentletrap book. Guide to the recent Epitoniidae of the world. 245 pp. Arti Grafiche La Moderna: Rome.

Wenz W. 1940. Gastropoda. Teil I: Allgemeiner Teil und Prosobranchia. In: Schindewolf OH. (ed.), Handbuch der Paläozoologie 6(1): 721-960. G. Borntraeger: Berlin.

Yamashiro H. 1990. A wentletrap Epitonium bullatum associated with a coral Sandalolitha robusta. Venus 49: 299-305.

Zahn LP. 1980. Living together in the sea. 416 pp. T.F.H. Publications: Neptune.

Received: 18 July 2005

Accepted: 1 August 2005 
